\title{
TIPOLOGÍA DE LA CERÁMICA BAJOMEDIEVAL Y \\ MODERNA SEVILLANA (S. XV-XVIII): \\ I, LA LOZA QUEBRADA DE RELLENO DE BÓVEDAS
}

\section{TYPOLOGY OF LATE MEDIEVAL AND MODERN SEVILLIAN COARSEWARE (15TH TO 18TH CENTURIES AD)}

\author{
Por \\ FERNANDO DE AMORES CARREDANO \\ NIEVES CHISVERT JIMÉNEZ
}

RESUMEN: En este artículo se ofrece por vez primera una tipología de 212 formas de cerámicas comunes producidas en Triana (Sevilla), Marchena y Carmona entre los siglos XV a XVIII. Los datos proceden de las colecciones de vasos defectuosos rescatados de los rellenos de bóvedas de edificios. Se garantizan con ello lugares de producción exactos y cronologías precisas para series de vasos completos.

\begin{abstract}
This article offers the first typology of 212 shapes from 15th to 18th centuries Triana (Sevilla), Marchena and Carmona coarse ware. The information has been recorded from the interior of a large number of well dated vaulting roofs. So that it is possible to determine exact production sites and precise chronologies of complete vessels series.
\end{abstract}

Los estudios sobre cerámica común cristiana de la Baja Edad Media y Moderna (ss. XIII-XVIII) son prácticamente inexistentes en el caso de la Baja Andalucía. Las causas de tal carencia se corresponden fielmente a la falta de interés habida por parte de la investigación arqueológica por estas etapas del desarrollo histórico.

Es fácilmente comprobable cómo ciertas etapas de nuestro pasado, sin tradición investigadora y de contínuo registro en la actualidad, tan siquiera se han dotado de los necesarios instrumentos descriptivos de sus artefactos. Ello permitiría avanzar con mayor rapidez en otros niveles de análisis e interpretación que redunden en beneficio de la solvencia de la arqueología en las etapas medievales y postmedievales.

La arqueología urbana y la arqueología de los monumentos han sido incorporadas por pleno derecho y con especial énfasis en años recientes y sólo a través de su aplicación ha podido surgir un registro arqueológico correspondiente a tales etapas. 
Como contraste con esta situación es singular que haya existido desde los años 70 una dependencia científica de Andalucía Occidental con respecto a los Estados Unidos de América en ciertos aspectos de la arqueología postmedieval sevillana (fund. ss. XVI-XVIII). Ha sido el desarrollo de la arqueología histórica sobre las colonias españolas en el área caribeña y del Sur de EEUU el que ha propiciado avances muy significativos sobre las series cerámicas sevillanas de los siglos XVI y XVII.

Para los americanos, la necesidad básica de contar con aquellos instrumentos descriptivos del registro español a los que hacíamos mención se vio favorecida por el hecho de disponer de documentación de archivo -Archivo General de Indias en Sevilla- necesaria para la datación de establecimientos coloniales, muchos de ellos de corta duración. Si a ello añadimos la circunstancia de que Sevilla fue la metrópoli que con exclusividad mercaba con América, tenemos un muy singular armazón sobre el que descansan no pocos estudios sobre artefactos españoles de la Edad Moderna, especialmente las mayólicas, y de estudios interpretativos sobre aspectos de la historia colonial que hubieran sido imposibles sin estas bases instrumentales. Estas colecciones han recibido mayor atención en su estudio que las lozas bastas o cerámicas comunes por el hecho de ser fácilmente reconocibles y buena herramienta de datación (Goggin, 1968; Lister y Lister, 1987; Deagan, 1987).

En el caso de Sevilla, las intervenciones arqueológicas sobre la ciudad y sobre Triana, el barrio alfarero, han brindado abundantes colecciones desde el año 1984 que sólo recientemente están siendo objeto de la sistematización que merecen (Amores y Chisvert, 1991; Pleguezuelo, 1992; McEwan, 1992; Myers et al. 1992; Amores et al. e.p.)

El proyecto de investigación arqueológica realizado en La Cartuja de Sevilla desde el año 1987 a 1991 con motivo de su restauración para la Expo'92 tuvo especiales resultados en la fase Cartuja (1400-1836). Las excavaciones, muy complejas, se desarrollaron tanto en el medio infrayacente cuanto en el emergente debido a la dificultad de lectura de las distintas estructuras resultantes de la dilatada y peculiar historia de este conjunto suburbano (Morales et al. 1987; Amores, 1992). Fruto de la metodología aplicada procedimos a la excavación de un buen número de bóvedas del antiguo monasterio que sospechábamos rellenas de recipientes cerámicos para su aligeramiento. De este modo llegamos a recuperar los lotes cerámicos de un total de ocho bóvedas de entre los siglos XV y XVI, reuniendo una colección sorprendente en cantidad y variedad de piezas resultantes de hornadas fallidas. ' (Amores et al. e.p.)

Ante el fuerte incremento de restauraciones de edificios históricos acaecido en estos últimos años, vimos la oportunidad de localizar y estudiar los rellenos de otras bóvedas sevillanas que estaban siendo consolidadas para así -desde el proyecto Cartuja- completar y contrastar nuestra tipología con nuevas aportaciones. De este modo pudimos incorporar las colecciones procedentes de bóvedas fechadas entre los siglos XV y XVIII de un total de diez edificios de Sevilla capital y provincia, Santiponce y Marchena, a 8 y $40 \mathrm{kms}$ de Sevilla respectivamente. A este esfuerzo hemos añadido las colecciones cerámicas de un grupo de bóvedas procedentes de la localidad de Carmona, a $30 \mathrm{kms}$. de Sevilla, extraídas en restauraciones de los años 70 y de actuaciones incontroladas sobre un edificio concreto de Sevilla bien fechado. ${ }^{2}$

Hemos de señalar que las colecciones cerámicas de bóvedas no han sido valoradas hasta la fecha, por lo que hoy hemos de lamentar la pérdida de muchas de ellas, desaparecidas por completo en restauraciones de décadas pasadas. Sabemos que una labor detectivesca brindaría la detección de ejemplares procedentes

1. Las bóvedas de La Cartuja fueron excavadas por los arqueólogos R. Fernández, N. Chisvert, J. López Torres, M. Rueda y M. Vera mientras que las labores de registro fueron llevadas a cabo bajo por A. Fuentes y N. Chisvert bajo la dirección de F. de Amores. Los dibujos de este trabajo están realizados por Pedro Mora Frutos.

2. En el futuro nuestra tipología se verá incrementada con la incorporación de nuevas colecciones procedentes de otras bóvedas de Sevilla y localidades próximas. 
de restauraciones en colecciones particulares tal como aprovechamos tímidamente en este artículo. Con respecto a instituciones de la Administración conocemos grupos de piezas en las dependencias del Alcázar y en los almacenes del Museo Arqueológico de Sevilla procedentes de restauraciones de cubiertas de edificios sevillanos que se habían salvado de la destrucción y la rapiña. Su porcentaje es, por lo demás, mínimo si se considera la ingente cantidad de piezas extraídas de una sola de las bóvedas excavadas sistemáticamente en la Cartuja. ${ }^{3}$

Los únicos casos en que teníamos constancia de que los lotes cerámicos de las bóvedas habían despertado algún interés científico procedían de autores catalanes y levantinos, o extranjeros. En estos trabajos se recorre la historia de tan peculiar técnica de origen romano y desarrollo típicamente medieval cristiano (Lister y Lister, 1981; Bassegoda, 1983) o se presentan diversos rescates de colecciones (LLubia, 1968; Francovich y Gelichi, 1986; Figueira, 1991; Amigues et al. e.p.)

Los archivos sevillanos ya habían aportado información complementaria a este respecto en varios documentos publicados por José Gestoso en su monumental obra (1903: 370-451) y que no habían sido valorados hasta la fecha. Se trata de los contratos de adquisición de loza quebrada a varios olleros de Triana para el relleno de las bóvedas de la Catedral en los años 1467, 1498 y 1513 . Entre ellos destacamos el encargo de 22 cargas de «jarras e cantaros»al ollero Diego Rodriguez para el relleno de la bóveda de la Capilla de la Antigua en 1512, material que incluimos en este estudio. ${ }^{4}$ Los documentos recogidos por Gestoso en el Archivo Catedralicio dan pie para esperar nuevos datos procedentes de la investigación documental $^{5}$.

\section{LA COLECCIÓN DE BóVEDAS CON ALIGERAMIENTO CERÁMICO DE SEVILLA}

El conjunto de bóvedas sevillanas con aligeramiento cerámico que recogemos en este estudio responde a una variada tipología y abarca una ámbito cronológico que comprende los siglos XV al XVIII.

Un aspecto que debe ser tenido en cuenta es el diferente grado de calidad que tiene el registro que presentamos. Contrasta por un lado la abundante colección de vasos diferentes en bóvedas controladas por nosotros en su excavación (Cartuja y Atarazanas) con respecto a otras en las que hemos accedido a su información básica (lugar exacto de hallazgo y datos generales) pero que previamente han estado sometidas a varios procesos de pérdida u ocultación de datos. Entre ellos el más usual es el de reparto de vasos entre los diversos profesionales de la obra. Es el gusto personal el que selecciona las captaciones, entre las que destacan los vasos de menor tamaño o más anecdóticos, éstos muchas veces de escasa

3. Hay que llamar la atención sobre la dificultad que entraña otorgar fechas a priori procedentes de dataciones conocidas del edificio de origen a colecciones antiguas que no han contado con el debido control arqueológico. En el caso de la Cartuja (Sala Capitular) y San Isidoro del Campo (Sala Capitular) hemos podido comprobar que las fechas de los rellenos de bóvedas no se corresponden con las fechas de construcción de la edificación sino a reformas posteriores. Estas pueden constar en Archivo (S. Isidoro, gracias al estudio histórico realizado por P. Respaldiza) o detectarse en el proceso de excavación. Por todo ello, entendemos que las colecciones antiguas sirven de referencia global debiendo ser ratificadas en sus dataciones a través de registros fiables.

4. La Capilla de la Virgen de La Antigua fue restaurada para el evento de 1992 por su vinculación con la figura de C. Colón. Por vez primera, en época reciente, se abrió una bóveda de la catedral para proceder a su consolidación. Gracias al arquitecto A. Jiménez pudimos acceder a su relleno cerámico.

5. Tenemos constancia de documentos sobre encargos de loza quebrada para el relleno de las bóvedas de la Casa Lonja de Sevilla (actual Archivo de Indias) que nos ha comunicado amablemente el Dr. A. Morales Martínez. No obstante, la precisión de fechas que aportan para la loza no ha podido ser aprovechada hasta la actualidad por no haber sido abierta ninguna de aquellas. 
presencia en los conjuntos. Otro proceso de pérdida es el propio de la extracción ya que, al tratarse de lozas quebradas, se suelen romper si no se extraen con cuidado, cosa usual al presentarse en gran número. La abundancia de unos tipos sobre otros y su mayor o menor robustez conforman las variables para definir el resultado final, al que hay que añadir la selección anterior. El último azar que puede afectar a la colección registrada es el de una apertura y control parcial sobre una bóveda, lo cual ha ocurrido varias veces. En este caso se ha extraído una selección de lo que ha aparecido en un primer momento dejando el resto de la bóveda sin abrir si no era necesario para su restauración. Este caso (S. Isidoro del Campo, p. ej.) no daña a la integridad de la colección que sigue ejerciendo la función para la que fue usada sino a su conocimiento lo cual aceptamos de buen grado.

Hasta la fecha hemos estudiado los rellenos cerámicos de las siguientes bóvedas:

A. Cartuja de Sevilla. Claustro de monjes. Celdas O y P. Bóvedas de arista, mediados s. XV. 41 formas diferentes.

B. Cartuja de Sevilla. Capilla de Santa Catalina. Bóveda de crucería, finales s. XV. 49 formas.

C. Monasterio de San Isidoro del Campo (Santiponce). Sala Capitular. Bóveda de crucería, años 14681492. 18 formas. $^{6}$

D. Cartuja de Sevilla. Sala Capitular. Bóveda de crucería, finales s. XV o principios s. XVI. 13 formas.

E. Iglesia de San Juan Bautista (Marchena). Abside. Bóveda de nervaduras estrelladas, años 14901510. 8 formas. ${ }^{7}$

F. Catedral de Sevilla. Capilla de la Virgen de la Antigua .Bóveda de crucería, año 1512. 9 formas.

G. Monasterio de San Isidoro del Campo (Santiponce). Claustro nuevo. Bóvedas de arista, principios s. XVI. 2 formas.

H. Capilla de Maese Rodrigo (Sevilla). Presbiterio. Bóveda de crucería, primer cuarto s. XVI. 1 forma. ${ }^{8}$

I. Cartuja de Sevilla. Almacenes de Legos. Bóvedas de cañón, primera mitad s. XVI (¿1505 a 1525?). 20 formas.

J. Iglesia de San Juan Bautista (Marchena). Naves laterales. Bóvedas de arista, año 1556. 17 formas.

K. Hospital de las Cinco Llagas. Crucero Norte del Patio del Recibimiento. Bóvedas de cañón con lunetos, segunda mitad s. XVI. 6 formas. (Actual sede del Parlamento Andaluz).

6. Agradecemos el conocimiento de esta colección a P. Respaldiza

7. Agradecemos el control y conocimiento de estas colecciones J.L. Ravé. Hacemos extensivo nuestro agradecimiento al cura párroco de S. Juan Bautista D. Juan Ramón Gallardo.

8. Agradecemos a A. Jiménez Martín la noticia y la cesión del único albarelo cuya procedencia es indudable de Sta. María de Jesús al igual que el acceso a la colección procedente del Hospital de las Cinco Llagas. 
L. Cartuja de Sevilla. Claustro de monjes. Celdas Q, R y capilla. Bóvedas de arista, s. XVI. 26 formas.

M. Iglesia de la Trinidad. Nave lateral derecha. Bóveda de medio cañón, año 1629.4 formas. ${ }^{9}$

N. Antiguo convento de los Terceros. Patio de la Virgen. Bóvedas de arista, s. XVII. 8 formas (Actual sede de Emasesa).

O. Convento de San José (Carmona). Iglesia. Bóvedas de arista, segunda mitad s. XVII. 8 formas. ${ }^{10}$

P. Antiguo Noviciado de San Luis. Claustros e iglesia. Bóvedas de arista y de cañón rebajado con lunetos, fines s. XVII e inicios s. XVIII. 19 formas. (Actual Centro Andaluz de Teatro).

Q. Iglesia del Salvador (Carmona). Bóvedas de arista, hacia 1720.8 formas.

R. Atarazanas de Sevilla. Bóvedas de cañón, mediados s. XVIII. 26 formas."

S. Antiguo Colegio de San Telmo. Galerías de fachada. Embotijado bajo solería, segunda mitad s. XVIII. 7 formas. (Actual sede de la Presidencia de la Junta de Andalucía). ${ }^{12}$

En este grupo hemos incluido un grupo de piezas que no proceden de bóvedas, sino de debajo de los pavimentos del Palacio de San Telmo. El embotijado es un ejemplo más del reciclaje de cerámicas en la edificación muy corriente en las casas sevillanas hasta el s.XIX, y cuyo objeto era el de aislar los interiores habitables de la humedad, muy alta en Sevilla. Poseemos otros lotes cerámicos procedentes del subsuelo de la Cartuja de Sevilla y que desempeñaron la misma función aislante, pero hemos preferido no incluirlos por ofrecer algunos problemas de datación. En el caso de las piezas del Palacio de San Telmo hemos decidido incluirlas en nuestra tipología por la perfecta concordancia que existe entre los datos proporcionados por la arquitectura de las salas en las que aparecieron (s. XVIII) y los derivados de la comparación tipológica.

\section{VALORACIÓN GENERAL}

La información que aportan las lozas quebradas y de avería (Gestoso 1903: 64, 129, 370), vasijas de loza común, ordinaria o basta con desperfectos de cocción, es de gran trascendencia para la arqueología. Su singularidad abarca una serie de características que es conveniente resaltar:

1. Se trata de vasos que se conservan completos cuyo conocimiento es muy difícil adquirir de otro modo para el arqueólogo. La cerámica común registra una gran diversidad formal y es frecuente que se trate de tamaños mayores que las lozas finas por lo que es usual hallarla muy fragmentada. El único método de conocer formas completas hasta la fecha ha sido el recurso a las escasas representaciones incluidas en la

9. Agradecemos la noticia del hallazgo a A. Vallejo, aparejador de las obras.

10. Agradecemos la consulta de la colección al vecino de Carmona M. Fernández.

11. Las bóvedas de Las Atarazanas fueron excavadas por A. Quirós.

12. Esta información la debemos a J.M. Rodriguez Hidalgo. 
pintura de caballete del momento (especialmente el s. XVII) la cual refleja a veces vasos y diverso menaje (Lister y Lister, 1987: 147 ss., 307-309; South et al., 1988: 213 y ss.; Seseña, 1991), acercamientos etnográficos o hallazgos completos procedentes de pecios subacuáticos (Martin, 1979; Sassoon, 1981)

2. Son una inmejorable fuente de datos para conocer y completar las tipologías de la producción alfarera de una localidad. El hecho de que no exista reparo alguno (en formas y tamaños) para el reuso de cerámicas en el relleno de las bóvedas incorpora un factor de correspondencia bastante elevado entre las colecciones halladas en las bóvedas y el repertorio formal de una localidad, que en un futuro se podría fijar con bastante exactitud.

Por otro lado, el radio de dispersión que se le puede asignar a la reutilización de las producciones averiadas de una localidad es mínimo debido a que se trata de material muy barato que sería costoso encargar a lugares lejanos. De este modo, es correcto usar el criterio de una fabricación local, o del núcleo más cercano con tradición alfarera, para la filiación de las colecciones quebradas de un edificio. No obstante hay que tener presente otras posibilidades como es la distribución fluvial, muy barata, de las lozas quebradas. Es el caso de puertos americanos o Sanlúcar de Barrameda, distante unos 90 kms. de Sevilla pero conectada con ésta por el intenso tráfico fluvial del Guadalquivir. Recientemente se han rescatado colecciones en Sanlúcar que deben proceder de Sevilla. ${ }^{13}$

3. Se trata de contextos cerrados que responden a asociaciones de vasos con una misma cronología. Esta se puede establecer por aproximación de acuerdo con los estilos arquitectónicos en los que se enmarca, si no se dispone de dataciones exactas extraídas de la documentación escrita, siempre complementada por las precisiones de la observación arqueológica.

Esta singularidad separa a la cerámica de relleno de bóvedas de otras colecciones de loza quebrada que frecuentemente se hallan en Sevilla utilizadas como aislamiento contra la humedad bajo el suelo. En tal caso, se trata de mejoras en la construcción de una edificación precedente sin que se tenga conocimiento del momento exacto de la obra. Aparte, la regularidad horizontal de la cámara a construir bajo el suelo fuerza la selección de formas muy estandarizadas y abundantes para facilitar la operación. Hemos podido comprobar que las formas más usuales para los rellenos antihumedad son las botijas y los cangilones, de similar tamaño y de abundante producción, por lo que revisten menor interés para el arqueólogo.

4. Se trata de fechas de producción, no de uso, a diferencia de los contextos arqueológicos urbanos, por lo que se puede seguir con mayor nitidez su evolución y circunstancias. No obstante, a veces se observa la inclusión en las bóvedas de recipientes ya usados lo cual es más frecuente en lugares sin producción cerámica que en Sevilla, donde también se detectan. No es anómala la incorporación de ollas de cocina usadas en el s. XV, o de una abundante colección de orzas o jarras aparecidas en las Atarazanas (s. XVIII) de fabricación no sevillana. En tales casos, puede ser incierto el lugar de procedencia pero son reutilizaciones próximas en el tiempo por tratarse de envases industriales o de corta vida. ${ }^{14}$

5. Según los estudios comparativos que hemos realizado sobre los rellenos de diferentes bóvedas y lugares, cada conjunto corresponde con seguridad, en un porcentaje muy elevado, a la producción de un taller. Gracias a ello se pueden extraer valiosas conclusiones acerca de especializaciones, mercado, variantes zonales, estructura de los talleres y oficios, etc. Esta observación puede tener menos fuerza cuando se trata de bóvedas de gran tamaño para cuyo aligeramiento se hizo necesaria la concurrencia de gran número de vasos. En tal caso parece razonable pensar que se abastece de más de un taller u origen.

13. Agradecemos la información y consulta a L. Perdigones y $\mathbf{M}^{\mathrm{a}} \mathbf{L}$. Lavado. También nos indican acerca de hallazgos controlados en bóvedas de edificios del Puerto de Sta. María lo cual va ampliando el repertorio y su problemática.

14. Este hecho afecta en especial a las construcciones americanas donde se reusan frecuentemente botijas sevillanas. Por ello es importante hacer constar si se trata de piezas quebradas o no. 
Es el caso de las Atarazanas, donde en una sola bóveda de cañón se pueden contar hasta 600 vasos, evidentemente de diferentes talleres o procedencias.

A este respecto hemos comprobado que si bien todas las producciones averiadas pueden ser utilizadas para el relleno de bóvedas, sólo existe cierta selección de un tipo de vaso para las partes inferiores de las enjutas. Las dolias (núm. 33 a 38) en los siglos XIV a XVI o las tinajas (núm. 1 a 5) son preferidas para este fin debido a que se ajustan a la perfección a este espacio piramidal utilizando para el resto del relleno los demás desechos disponibles. Según ésto no podemos asegurar que en el mismo taller se produzcan las dolias y el resto de la colección presente aunque no sería extraño ya que están realizados con las mismas pastas cerámicas que los cántaros y cangilones a la que acompañan.

\section{TIPOLOGÍA DE LAS CERÁMICAS COMUNES DE LAS BÓVEDAS}

Hasta la fecha la investigación sobre cerámicas bajomedievales y modernas se ha reducido al estudio de las mayólicas, lo cual nos ha enfrentado a la falta de precedentes clasificatorios para las series comunes que aquí sistematizamos. Tan sólo algunos investigadores norteamericanos (South et al. 1988; Deagan, 1987) han establecido diversas clasificaciones de materiales sevillanos basadas en asociaciones de piezas por barros y tratamientos dados a las superficies, lo cual les ha llevado a incluir tipos muy diversos en un mismo grupo. Aunque nos parece válido este método clasificatorio para las cerámicas americanas, que pueden tener procedencia varia, pensamos que no es el más apropiado para una clasificación de lotes de piezas cuyos lugares de origen son probadamente reconocidos.

Para la elaboración de esta tipología hemos optado por un doble criterio que obedece, de un lado, a una división funcional que agrupa las piezas en amplios conjuntos definidos por un mismo uso, inducido a partir de perduraciones de carácter etnográfico y pictórico, y de otro, al empleo de la terminología tradicional para la designación de cada tipo formal concreto. Aún reconociendo que este sistema puede contener algunas ambigüedades, derivadas de usos diversificados de un mismo tipo de pieza, creemos que representa un primer intento de una forma racional y útil de ordenación. En cuanto a la elección de la terminología tradicional frente a la histórica se justifica por el desconocimiento existente sobre la misma de esta época, que sólo podría superarse a través de un estudio en profundidad de la documentación histórica y de estudios de capacidades de las piezas, tarea que excede los límites de nuestro trabajo. En el caso de que aquellos se llevaran a cabo, habría que realizar las oportunas revisiones ${ }^{15}$. Por lo demás, los nombres asignados a las piezas perduran aún en los ambientes alfareros andaluces (Ministerio, 1981). Si bien es posible encontrar algún término tradicional que contenga una cierta ambigüedad, también es cierto que ésta se incrementa en la terminología histórica como tendremos oportunidad de comprobar.

Nuestra tipología se ordena en torno a cuatro grupos principales de usos cerámicos, como son : Almacenamiento; Transporte; Agrícola-Industrial y Doméstico, éste subdividido en los siguientes subgrupos: Doméstico General, Despensa, Mesa y Cocina. ${ }^{16}$

15. El trabajo de Lister y Lister (1976) supuso un gran esfuerzo por sistematizar los términos relacionados con la industria alfarera tradicional española; aunque con omisiones y errores, este trabajo, escasamente conocido en España, da una idea del avance de la investigación norteamericana al respecto en aquellas fechas. A este respecto el trabajo de (Sanchez, 1993) ofrece una primera aproximación bastante extensa y contrastada sobre terminología histórica. El autor expone sin embargo las dificultades que existen para sistematizar esta información como sería de desear. A la fuente clásica del Tesoro de la Lengua Castellana del Ldo. S. de Covarrubias de 1611 , une otras fuentes literarias y documentales de modo exhaustivo. 1988.

16. Criterios similares para la discusión tipológica y su sistematización funcional han sido propuestos por Beaudry et al., 
El índice de las formas se ha realizädo de modo numérico y consecutivo, del 1 en adelante. En las figuras se incluye la forma con su número de clasificación y las letras correspondientes a los edificios en que se han hallado $(A, L . .$.$) cuyo índice se ha incluido con anterioridad. La designación de los conjuntos edilicios$ se ha establecido desde el más arcaico al más moderno. En esta catalogación hemos hecho un esfuerzo por ordenar la sucesión de formas y de cronologías dentro de las series distinguidas. De cualquier manera, las nuevas formas que se presentaren en el futuro serían numeradas a partir del último aquí publicado para facilitar su cita.

En cuanto al aparato descriptivo omitimos deliberadamente la descripción formal, redundante cuando disponemos del dibujo, y solamente atendida cuando se refiere a detalles de interés, variantes, etc. Asimismo hemos decidido omitir las descripciones literarias de las características y color de los barros, subjetiva y ambigua a todas luces y que hoy día sólo puede ser definida seriamente por métodos analíticos. ${ }^{17}$ Básicamente se trata de dos tipos de pastas más comunes para Triana (Gestoso, 1903: 61), una depurada para la labor fina, típica blanquecina-amarillenta utilizada para las lozas vidriadas finas, mayólicas, jarras, jarritas, etc.; otra para la labor áspera, de composición y superficie más bastas, del mismo color pero a veces con zonas rojizas a causa de la oxidación por la mayor temperatura necesaria para su cocción, con desgrasantes de cuarzo, usada para los recipientes de mayor tamaño como cántaros, cangilones, botijas, orzas, etc. Aparte y con carácter minoritario se documenta el barro rojo típico de las cerámicas de cocina (ollas, cazuelas...). Los barros de Carmona y Marchena son diferentes, bastos y poco depurados.

\section{GRUPO ALMACENAMIENTO}

En este grupo se reúnen todos aquellos recipientes de tamaño mayor cuyo fin prioritario fue el de servir de contenedores de productos varios que se mantenían almacenados, tanto en ambientes domésticos como en los rurales o urbanos de producción. Lógicamente, al tratarse de grandes recipientes, el término "almacenamiento» podría resultar estrecho ya que estos recipientes se usaron igualmente en los procesos de transformación industrial. Por ello este grupo se asocia en el orden de aparición al agrícola-industrial. Lo mismo podría afectar a otros recipientes, tales como el «lebrillo», de uso general, doméstico e industrial.

TINAJAS. (núm. 1 a 5)

Las tinajas están escasamente representadas debido a que por su gran tamaño sólo podían emplearse para el relleno de las enjutas de las bóvedas en su parte más amplia; aparecen en conjuntos arquitectónicos del siglo $\mathrm{XV}$ y primeros años del siglo $X V{ }^{18}$. No están vidriadas y a veces portan marcas incisas en el hombro. El destino de estas piezas era el de contenedores de productos varios, tanto sólidos, como semisólidos, o líquidos.

17. Un esfuerzo considerable en la personalización de los barros de Triana en la Edad Moderna se ha realizado por la Smithsonian Institution con la colaboración de uno de nosotros. Véase a tal efecto, (Myers et al., 1992).

18. Las tinajas han sido vasos de uso muy frecuente en las sociedades medieval, moderna y contemporánea y por lo general de formas básicas muy reiterativas. La recopilación de sus variantes, locales más que cronológicas, es más fácil realizarla a través de colecciones rurales conservadas, anticuarios, etc. Una tipología de tinajas mudéjares decoradas se puede consultar en (Alonso y Lasso, 1982). 
TINAS O TINAJONES. (núm. 6 a 10)

Al igual que las tinajas, su aparición en las bóvedas es muy esporádica debido también a su gran tamaño. La mayoría de los ejemplares proceden de una misma bóveda, de Marchena, fechada entre 1490 y 1510 y presentan escasa diversidad formal que se ha mantenido básicamente a lo largo del tiempo. Grandes vasos sin vidriar, las tinas se destinaban principalmente a la recogida de aguas de lluvia, aunque también se emplearon para el aseo personal y procesos industriales.

\section{GRUPO AGRÍCOLA-INDUSTRIAL.}

Grupo donde hemos reunido aquellos recipientes dedicados de modo específic $\supset$ a labores de producción agrícola, pecuaria o industrial.

\section{CANGILONES. (núm. 11 a 22)}

Los cangilones, también denominados «arcaduces», tienen conocidos precedentes islámicos, de menor tamaño y mas aristados. Como piezas componentes de las norias se han empleado hasta este siglo en el sistema de irrigación de huertas y jardines.

La idoneidad de los cangilones para el aligeramiento de bóvedas hace que estén bien representados en la colección; también fueron preferidos como aislantes de humedad bajo los pavimentos, aunque no hemos incluido ningún ejemplar de esta procedencia.

Lo primero que salta a la vista es la gran variedad de formas y tamaños representadas, lo cual ha de ser indicativo de la simple adaptabilidad de estos recipientes a las norias, a su vez de tamaños y capacidades diversas; por esta razón, en absoluto exclusiva de estas piezas, los alfareros dieron rienda suelta a sus gustos y habilidades personales en la elaboración de unos productos cuyo único requisito era el de disponer de un entalle por donde amarrarlos a las norias.

Hemos incluido deliberadamente una serie extensa de los mismos por el interés que estas piezas tienen para los arqueólogos debido a la frecuencia de su aparición. Se puede comprobar que casi no existen indicadores cronológicos en la diversidad formal. Unicamente podemos anotar un mayor preciosismo marcando el entalle, a modo de faja, en los ejemplares más primitivos $(11,12)$, lo que después se resuelve con el simple estrangulamiento, aligerando el tiempo de torneado; Otro detalle, de tendencia general, es la ampliación del tamaño desde el s. XV en adelante. ${ }^{19}$ Igualmente se distingue gran diferencia entre el conjunto de Sevilla y el ejemplar de Carmona, que responde a sus propias tendencias locales.

\section{CÁNTARAS DE ORDEÑO O DESTILACIÓN . (núm. 23,24)}

Forma peculiar restringida básicamente al s. XV y de escasa aparición en las bóvedas, no constan vidriadas aunque no eliminamos tal posibilidad. La inclusión de estas cántaras en el grupo agrícolaindustrial se explica por la probable adaptación de estas piezas a la labor de ordeño, pues así parece indicarlo la longitud de sus cuellos y las asas para verter. De todas formas no disponemos de certeza para esta adscripción propuesta.

19. Sería sugerente la hipótesis de relacionar este detalle de tamaño con un incremento del rendimiento de los ingenios, mayor tamaño y mejor ubicación de las norias; incremento de la superficie de cultivos irrigables en la propiedad, etc. en la Edad moderna. 
Otra posibilidad vendría sugerida por el conocimiento reciente de unas formas similares vidriadas en Portugal. Se trata de Cántaras de destilación de aguardiente para ubicar bajo el alambique. Esta opción sería de todo punto interesante y habrá que trabajar en sus implicaciones.

Un ejemplar similar al núm. 23 ha sido publicado procedente de una bóveda del siglo XV de la Cartuja de Nuestra Señora de la Defensión, de Jerez (Lister y Lister, 1981: fig.5; 1987: fig. 94,e). Este hallazgo, unido a otros allí recuperados, como escudillas típicas de Triana, algunas de producción exclusiva para La Cartuja de Las Cuevas donde hemos recuperado numerosos ejemplos (Lister y Lister, 1987: fig. 67-70), nos hacen suponer una dependencia de Jerez con respecto a Triana en su provisión de alfarería. No sabemos si la dependencia se circunscribe al eje cartujo o se pudiera ampliar a la comarca de Jerez, Sanlúcar de Barrameda, El Puerto de Santa María...20

\section{RECIPIENTES PARA LA FABRICACIÓN DE AZÚCAR DE CAÑa}

1/ FORMAS AZUCARERAS. (núm. 25,26)

Moldes sin vidriar de forma cónica fabricados especialmente para cuajar el azúcar de caña (González y Fernández, 1990)

Aunque su aparición entre los rellenos de las bóvedas es anecdótica también fueron usadas en el aligeramiento de las bóvedas barcelonesas de Santa María del Mar, del siglo XIV (M.Riu, 1984:163-171) y en el convento de S. Francisco en Santo Domingo (Lister y Lister, 1981:75).

En Sevilla, región no productora de caña, se fabricaron formas azucareras para abastecer a los ingenios americanos y a las refinerías que funcionaron en la ciudad desde principios del siglo XVI hasta 1574 (Río, 1990: 131-155; Amores y Chisvert, 1991: 163-176). Otra ciudad metropolitana que, como Sevilla, no producía azúcar, Lisboa, se convirtió en el siglo XVI en el más afamado centro productor de formas, que se enviaban a los trapiches de Madeira, Canarias, e incluso la América española.

Los ejemplos que presentamos corresponden a la $1^{\mathrm{a}} 1 / 2 \mathrm{~s}$. XVI, quizás al primer cuarto (Cartuja) y a la $2^{\mathrm{a}} 1 / 2 \mathrm{~s}$. XVI (Cinco Llagas). Los primeros deben estar en relación directa con el aprovisionamiento a los trapiches de La Española, primer lugar de Indias donde se ensaya masivamente el cultivo de azúcar. Gestoso (1903: 372) publicó un interesantísimo documento en el cual el alfarero sevillano Diego Ferrandez de Moron se compromete en 1505 con Lope Alfonso de la Muela al envío de 1000 formas a Santo Domingo. Esto podría indicar la temprana producción de azúcar en La Española y la dependencia con respecto a Sevilla para el abastecimiento de equipamiento industrial. Esta documentación no ha sido puesta en relación con la utilizada por los estudios históricos y complementaría aquellos datos que nos indican que los primeros intentos por cristalizar el guarapo son de 1505-6 y 1512 por Alonso Gutierrez de Aguillon y Miguel Ballester respectivamente. En 1514-15 se comienza a fabricar por Gonzalo de Vellosa, aunque por aquellos años Alonso Gutierrez de Aguillon y Hernando Gorjon tenían edificado un trapiche en Azúa (La Española) (Rio, 1991: 306)

20. La expansión de la industria cerámica sevillana está por hacer. Así como se ha estudiado su difusión a través de la azulejería de arista por Europa y América por parte de arqueólogos e historiadores del Arte y la mayólica moderna también cuenta con estudios importantes para América, no está sistematizada la expansión de todas sus producciones por la Península Ibérica. Trabajos recientes sobre contextos bajomedievales y modernos van abriendo posibilidades en este aspecto. Véase p. ej. (Varela y Varela, 1991) donde aparecen masivas representaciones sevillanas en Silves. 
Una vez que los trapiches comenzaron a producir azúcar con regularidad parece que debieron de autoabastecerse de formas, cuando menos parcialmente. A este respecto conocemos entre las cuentas de los ingenios el pago al ollero Pedro de Talavera por las formas y signos que hizo para la elaboración de azúcar para el ingenio Sanctiespíritus en Santo Domingo en 1523 (Rio, 1991: 364). Por el contrario no consta otro envío de formas de Sevilla a Indias mientras que sí aparecen entre los gastos de los ingenios otros productos de elevado coste, como el utillaje de cobre, donde se mantiene la dependencia tecnológica con Sevilla. La opinión de Lister y Lister (1987: 205) quienes argumentan una producción local de las formas antillanas debido a su mínima dificultad de fabricación es a todas luces una visión simplista ya que el tema es más complejo. A este respecto conocemos las dificultades de autoabastecimiento en varias islas, como Cuba, donde las formas producidas con los barros locales eran de mala calidad y constan pedidos de ellas a Portugal (Lopez, 1990: 203).

\section{2/ OLLAS DE PURGACIÓN. (núm. 27, 28)}

Son los recipientes sobre los que descansaban las formas azucareras y en los que escurría la melaza residual.

Son piezas similares a las orzas pero con ciertos detalles que las definen: sin vidriar, base plana y amplia, algo rechonchas y boca amplia con borde grueso exvasado para recibir a la forma. Han aparecido conjuntamente en una misma bóveda, hecho que no se había evidenciado en ningún otro conjunto, y que nos llevó a acoplar ambos recipientes, con resultado satisfactorio. En realidad tan sólo la aparición de ollas juntamente con formas en testares e ingenios ha permitido en otros lugares deducir el uso como recipiente de decantación de estas piezas, puesto que estas ollas, similares a orzas, han podido tener muchos otros usos (Gisbert, 1991: 256-262).

Las ollas de purgación están presentes sólo en la Península Ibérica tanto citadas en documentación cuanto halladas en excavación. En América parece que se utilizó un lugar para purgar denominado tendal con suelo de cañas donde se incrustaban las formas para no volcar (González y Fernández, 1990: 119). En el caso de Sevilla, las del Hospital de las Cinco Llagas ( $2^{\mathrm{a}} 1 / 2 \mathrm{~s}$. XVI) deben estar relacionadas con las refinerías locales. Es significativo por tanto que en la bóveda I de La Cartuja, del primer cuarto del s. XVI, se hallaran formas y cantimploras para comercio con América pero no ollas de purgación puesto que allá no las usaban mientras que eran necesarias para el refinado que se hacía en Sevilla, a las que deben corresponder las del Hospital de las Cinco Llagas, cuya fecha de producción indica evidentemente que no fueron fabricadas para América.

CONEJERA. (núm. 29)

Se trata de una única pieza hallada en bóveda cuyo uso como conejera deducimos de paralelos etnográficos (Llorens y Corredor, 1970: 172). El único ejemplar estudiado recuerda por su forma a un codo de atanor, pero la estrechez del orificio superior lo invalida como tal. La superficie interior está deliberadamente allanada, para proporcionar un fondo plano a una pieza de base curva.

\section{COMEDERO DE AVES. (núm. 30)}

Se trata también de una pieza única, cuyo uso deducimos igualmente de paralelos etnográficos (Llorens y Corredor, 1970: 145,170,202). La amplitud del agujero superior, más bien una boca, podría estar diseñada para el acoplamiento de otra pieza, como ocurre con los comederos fabricados aún en algunos alfares españoles. 
ALBARELOS. TARROS. (núm. 31,32)

Este tipo de recipientes está poco representado en los lotes cerámicos de las bóvedas reduciéndose a cronologías de fines del s. XV y comienzos del s. XVI. Los ejemplares recuperados presentan vedrío de color melado en el interior y en el exterior, a excepción de las bases.

Son tipos comunes, a diferencia de los ejemplares mucho más decorados y cuidados producidos en Italia, Manises o en la misma Sevilla (Gestoso, 1903: 114). El tipo cuenta con precedentes formales en Andalucía desde el siglo XIV. No contamos con ningún ejemplar vidriado en azul, moda decorativa cuya implantación en Sevilla atribuyen los Lister a influencias de la colonia genovesa asentada en la ciudad desde siglos atrás y dedicada a la comercialización, entre otras cosas, de productos medicinales (Lister y Lister, 1987: 129,200).

Su uso reconocido era contener productos de farmacia aunque también era usado como bote o tarro para especias y otros contenidos y usos domésticos.

\section{GRUPO TRANSPORTE}

En este grupo incluimos las piezas cuyo uso principal fue el de recipientes contenedores para el transporte de productos varios; en algunos casos, de forma secundaria, se emplearon también para almacenamiento doméstico, pero su conocido empleo masivo en el comercio fluvial y marítimo nos inclina por incluirlas en este grupo específico.

DOLIAS. ${ }^{21}$ (núm. 33 a 38)

Varía su forma en el cuerpo que puede ser de tendencia ovoide, más regular, o bien presentar un estrechamiento en la mitad inferior. No presentan decoración ya que la impresión sobre el barro fresco de un cordón de esparto horizontal en la arista del hombro que a veces aparece es la huella de la operación de unión de las dos partes en las que se hacían. En algunos ejemplares han aparecido marcas incisas. Tampoco han aparecido piezas vidriadas en las bóvedas aunque disponemos de un ejemplar completo de La Cartuja con vedrío melado interior y marca exterior pintada en almagre, sin contexto claro (núm. 38) que completa la versión del tipo.

Contamos con 19 ejemplares completos o casi completos, entre defectuosos y en buen estado aparente, además de fragmentos de bocas y cuerpos. La dolia es característica por su boca, moldurada para facilitar su tapado y sellado, constituyendo el fragmento mas significativo para su detección en el registro arqueológico si no contamos con la forma completa, más inusual. Como ocurre con las tinajas y tinas el tamaño de estas piezas condiciona su escasa aparición en los rellenos de bóvedas.

Creemos que estamos ante la primera «ánfora» sevillana medieval cristiana. Su actividad está documentada con cierta seguridad desde el s. XIV a partir de las fechas de excavación y de las bóvedas

21. El término dolia es de origen latino (plural de dolium) y se emplea en algunos documentos históricos. Nos obstante somos conscientes de que este nombre no tiene tradición sevillana. El nombre de este contenedor pudo ser «jarra» término bastante común en los documentos medievales (Childs, e.p.) que hoy día tiene diferente sentido. Ya que se trata de una de las series de envases comerciales sevillanos donde se aceptan denominaciones como «botijas» o «cantimploras» proponemos este de «dolias» para separarlas de aquéllas para su designación por el diferente espacio cronológico y geográfico en el que se enmarca. 
sevillanas datadas dentro del siglo XV y principios del s. XVI (núm. 34 de 1512). Es significativo que este tipo perdure tan sólo hasta principios del siglo XVI. En este momento debió sufrir un proceso de adaptación formal provocado por los nuevos retos del emergente comercio atlántico con la América colonial hacia formatos más robustos y de menor capacidad como son las botijas, de las que claramente son el precedente formal y funcional. Lo curioso es que esta forma no se utilizó en los albores del comercio americano aún cuando parece que estaba creada para comercio marítimo exterior de líquidos. ${ }^{22}$ Por el contrario, para el inicio del comercio atlántico se adaptó una variante de la cantimplora ${ }^{23}$ de dos asas vidriada (núm. $42,44,50$ ) desde fines del s. XV hasta mediados del s. XVI en que es suplantada definitivamente por la botija, ovoide y sin asas, derivación evidente de la dolia, su prototipo. Quizás el tamaño y la robustez fueran decisivos para el transporte atlántico de altura.

En la Península Ibérica se han detectado en Valencia donde se las incluye en el grupo «tinajas», con las mismas características formales, vedrío interior melado y marcas pintadas en almagre que la colección sevillana. (Amigues et al. 1992: fig.2, VI, VIa y VII). Todos los ejemplares proceden de las bóvedas del Convento de Sto. Domingo de Valencia, y su capacidad oscila entre los 22/33 litros (tipo VI), 33 litros (tipo VIa) y 44/57 litros (tipo VII). Las capacidades y las marcas pintadas no coinciden con las referidas en los documentos notariales valencianos para los envases locales. Todos estos detalles, los tipológicos, las capacidades y marcas, han puesto en duda desde un principio su procedencia valenciana ${ }^{24}$. Los autores sugieren un uso para comercio de aceite y no especifican una datación concreta aunque se refieren en general a los siglos XIV y XV.

Fuera del ámbito español han sido publicadas varias bocas típicas de dolias procedentes de Southampton en niveles datados en la 1 ${ }^{\text {a }} 1 / 2$ del s. XIV y en el s. XV (Platt y Coleman, 1975: 1291, 1308; Hurst, 1977 : fig. 33, 55-56) no descartando la posibilidad de un origen sevillano para transporte de aceite. La datación del s. XIV confirmaría una mayor antigüedad para el tipo que la que oferta nuestra colección, pudiendo pertenecer a esta serie los ejemplares similares rescatados en la demolición de la Iglesia de S. Miguel de Sevilla (s. XIV) conservados en el Museo Arqueológico, de los que se ha publicado alguno sin referencia (Lister y Lister, 1987: fig. 94,b).

Finalmente conocemos dos ejemplares de dolias procedentes de bóvedas de Serravezza (Toscana, Italia) datadas en el s. XVI, con anterioridad a 1520 , fecha que concuerda con las que presentamos de Sevilla (Francovich y Gelichi: 1986, 306-309, 311; fig. 5,2; tav. XI).

Nos parece especialmente interesante que por fin se identifique el lugar de producción de esta forma, huérfana hasta la actualidad y detectada en lugares y fechas del máximo interés. La dolia se erige por tanto en fósil guía del comercio marítimo de ¿aceite? bajomedieval sevillano abriendo sugerentes perspectivas para su estudio.

22. Goggin no recoge ningún ejemplar similar en su tipología, ni aparecen en otros estudios de autores norteamericanos. Es interesante indicar que parece que la dolia era un contenedor específico para comercio exterior. No suele aparecer en los registros arqueológicos urbanos de Sevilla y es suplantada absolutamente por los nuevos formatos de envases de comercio coloniales, lo cual indica una clarísima especialización industrial para el comercio exterior de la ciudad.

23. En mucho lugares se ha denominado «botijas» hasta la actualidad a lo que nosotros llamamos «cantimploras», término más usado para recipientes metálicos. Es sugerente la posibilidad de que las ánforas sevillanas, a las que denominamos «botijas» por terminología histórica, adquirieran este nombre por derivación de aquellas primeras que se usaron en el comercio colonial.

24. Pudimos contrastar información en directo con J.V. Lerma en Rabat quien, después de conocer nuestra comunicación (Amores y Chisvert, 1991) no tuvo dudas en asignar un origen sevillano para las dolias aparecidas en Valencia. 


\section{CANTIMPLORAS. (núm. 39 a 51)}

Los ejemplares hallados aparecen usualmente sin vidriar aunque hay ciertas series (núm. 42, 44 y 50) con vedrío interior y chorreo exterior que cubre las bocas y parte de los hombros. Los colores del vedrío oscilan entre verde oscuro y melado, produciéndose esta variación, a veces, en una misma pieza, indicando con ello que la tonalidad puede depender del grosor de vedrío aplicado y de las diferencias o mezclas en la cocción. Algunas piezas presentan marcas pintadas en color rojo (núm. 40).

La denominación elegida para estas piezas está ampliamente aceptada en la actualidad (Lister y Lister, 1976:31; Lister y Lister, 1987:132, Fig.78a,b). ${ }^{25}$ Algunos autores asocian su uso y difusión al ambiente medieval cristiano (Lister y Lister, 1976:31). Aunque se conocen precedentes desde Roma no es forma islámica, apareciendo claramente en momentos cristianos como en Lyon (Maccari, 1991: fig. 11) del s. X, s. XIV en Inglaterra (Hurst, 1977: 98,101) o principios del siglo XV elaborados en Portugal (Torres, 1990:135, fig.11; 1991:193, fig.19).

Las cantimploras propiamente dichas, denominadas a veces «barriles», son las de perfil achatado, mejor adaptadas al transporte en caballerías, carros o a la cintura, que parece haber sido su destino original, de amplio consumo y que aún sigue produciéndose en algunos alfares españoles. Otro detalle formal que las distingue es su cuello alargado y a menudo convexo como suele darse en los cántaros de agua.

$\mathrm{Al}$ igual que en otras series se pueden distinguir fácilmente las variantes locales en detalles formales, aparte de por sus barros. Las de Carmona (núm. 45,46 ) son robustas y pesadas por su barro basto, acaban lateralmente en dos conos pronunciados y su cuello es moldurado. Las de Marchena (núm. 47,51) son más estilizadas, con remates laterales de ombligo y pezón y cuellos cilíndricos alargados con pequeñas molduras.

Un grupo concreto de las cantimploras, las esféricas, boca abierta abocinada y vidriadas (núm. 42,44 y 50) se identifican con los primeros envases comerciales de transporte transatlántico como una adaptación de la cantimplora tradicional (Amores y Chisvert, 1991).

Con el material aportado por las bóvedas podríamos establecer tres tipos para estas cantimploras comerciales en función del tamaño de los cuerpos; la variante de boca ancha, no documentada hasta la fecha en América, debe estar relacionada con los contenidos sólidos:

1. Cantimploras grandes: altura total: $30-36 \mathrm{~cm}$. con dos variantes respecto a los diámetros de boca:

1.1. entre 7-9,5 cm. (Amores y Chisvert, 1991: lam.1,3)

1.2. entre 11-16,5 cms. (núm. 42)

2. Cantimploras medianas: altura total: $26-29 \mathrm{~cm}$. y $6,5-8 \mathrm{~cm}$. de diámetro en la boca. (núm. 44)

3. Cantimploras pequeñas: alturas total: $21-24,5 \mathrm{~cm}$. y diámetros de boca entre $6-7 \mathrm{~cm}$. (núm. 50)

De la variabilidad en las medidas de los tipos de cantimploras estudiados se deduce que su sistematización por capacidades resulta complicada, y que si en la época en que se produjeron existía alguna legislación sobre las mismas, éstas no se cumplían más que grosso modo. ${ }^{26}$

Goggin (1960) presentó su hallazgo y dispersión en los yacimientos americanos de la época inicial de la colonización catalogándolas como «Early Style Olive Jars» que este autor suponía acertadamente originarias de Sevilla.

25. En este sentido hemos modificado la terminología que empleamos en un artículo anterior para designar a estas piezas, que en aquella ocasión (primera en que las estudiábamos) recogimos bajo el nombre de «botijas peruleras» (Amores y Chisvert, 1991: 163-176).

26. Insistimos en que el estudio por capacidades de los envases comerciales está por hacer. No es complicado pero creemos que debe ser objeto de trabajos monográficos con otro enfoque. 
Las fechas asignadas por Goggin a este estilo, 1500-1580, algo reformadas posteriormente por el mismo Goggin a 1493 - ca.1575 (1968: 228) y por Deagan, 1493-1570 (1987:33), a partir del análisis de los ejemplares hallados en yacimientos coloniales tempranos del área antillana, son básicamente confirmadas por las piezas rescatadas de las bóvedas sevillanas. No obstante su aparición debe ser anterior, en un momento indeterminado de finales del s. $X^{27}$, mientras que la fecha final de producción la adelantaríamos, gracias a nuestros datos, a mediados del siglo XVI, cuando son suplantadas por las botijas. Se evidencia con ello la sustitución de un tipo de envase cerámico con una larga tradición y que había servido bien para el transporte terrestre y el marítimo de cabotaje, por otro tipo mejor adaptado al viaje ultramarino, más resistente y fácil de almacenar en los galeones, navíos sustitutos de las obsoletas carabelas.

El hallazgo de una cantimplora comercial completa del tipo mediano en Silves, Algarve (Portugal) (Varela y Varela, 1991: 471) junto a otras cerámicas sevillanas, aunque clasificadas erróneamente, refuerza su carácter de envase de productos alimenticios que iban asociados a exportaciones masivas de cerámicas por vía marítima.

BOTIJAS. (núm. 52 a 88)

Recogen la tradición reciente de las dolias, de similar procedimiento de fabricación, en dos partes al igual que las cantimploras, aunque las adaptan disminuyendo su tamaño y engrosando sus paredes y boca con la típica forma de rosco. Estos detalles avalan que faltaban robustez y manejabilidad para su almacenamiento en los primeros ensayos de envase para los rigores de la travesía ultramarina.

Las botijas representan la mayor parte del registro cerámico rescatado de las bóvedas sevillanas debido, de una parte, a su idoneidad para el relleno de los espacios creados por estas cubiertas, y de otra, a la abundancia de estos recipientes en el mercado. De hecho, su empleo masivo en las bóvedas y rellenos antihumedad a partir de mediados del s. XVI provoca una muy marcada monotonía en los lotes cerámicos estudiados.

Hemos establecido siete tipos principales ateniéndonos a la forma de los cuerpos y otros detalles, puesto que la gran variabilidad de las bocas complicaría en extremo la clasificación y parece responder más a especializaciones de talleres que a factores cronológicos o tipológicos; por otra parte, la oscilación en el empleo de barros es mínima y no permite destacarla como factor indicador de tipos.

Quizás se entienda que se ofrecen demasiadas variantes para los tipos reseñados pero creemos que existe especial interés por las botijas y, desde Sevilla, es nuestra intención ofrecer el máximo de elementos de juicio. Los investigadores americanos otorgan a estas series una trascendencia lógica por la relevancia que tienen para los estudios del comercio colonial español la cual no se ha visto correspondida hasta ahora en el ámbito sevillano por paradójico que parezca.

Tipo A: (núm. 52 a 65) Coincidente con el tipo A de Goggin (1960), quien primero sistematizó las botijas, es la forma más frecuente y de mayor tamaño, con una variedad en su perfil ovoide más o menos «inflado» o con cierto entalle en la parte inferior. Los bordes son de perfil semicircular o cuadrado en cualquier época y llevan resalte anular muy distintivo. Las variantes del núm. 56, con similar borde de perfil cuadrado se registran tanto en el s. XVI como en el s. XVIII, lo cual se podría defender para la serie en general. Este tipo puede llevar marcas incisas o impresas sobre el borde u hombro.

27. La fecha del relleno de la bóveda del Capítulo de la Cartuja no corresponde a su construcción, datada por documentos en 1453, sino a una remodelación posterior dentro del s. XV, que nosotros situamos con anterioridad a 1492. Podría ser que estos envases fueran adaptados para el primer tráfico atlántico con las Canarias, incorporada a Castilla en 1474 (Aznar y Viña, 1990). 
Los hallazgos de las bóvedas no permiten mantener los dos grupos cronológicamente diferenciados que establece Goggin entre las «Middle y Late Style», pues en bóvedas de fechas coincidentes aparecen indistintamente ejemplares de uno y otro estilo. La forma A del «Middle Style» y la A del «Late Style» se presentan en las bóvedas sevillanas como simples variaciones de un mismo Tipo (el A) con similar cronología.

Como peculiaridad anotamos una boca especialmente ancha (núm. 62) o un fondo plano (núm. 64) tardío al igual que los tipos E y F. El vedrío es escaso en este tipo y tardío, sólo al interior o por ambas caras y de color verde, quizás reservado a algún producto especial ¿vinagre, aguardiente?.

Detalle importante a destacar es la temprana fecha de aparición de estas series. El núm. 52 del último cuarto del s. XV recogido en S. Isidoro del Campo es sumamente importante. Coincidente con la fecha que asignamos a la aparición de las cantimploras comerciales tendríamos que admitir que también se realizaron las primeras adaptaciones desde las dolias a estas botijas primitivas aunque no se han registrado en América. En ellas se advierte menor tamaño y una boca estrecha no engrosada en rosco sino más parecida a las cantimploras y cántaros. Las núm. 53 y 54, también de S. Isidoro del Campo pero de principios del s. XVI, son igualmente pequeñas y en ellas se advierte ya un borde reforzado en rosco pero no tan robusto como las series clásicas.

Procedente de la Capilla del Sagrario de Sevilla, Lister y Lister (1981: 72, fig. 5,b) publican una botija de este tipo que sería de la primera mitad del s. XVII, hoy en el Museo Arqueológico de Sevilla.

Tipo B: (núm. 66 a 74) Identificado de modo coincidente por nosotros con la variante B de Goggin, es también una forma muy frecuente entre las botijas. De menor capacidad, es rechoncha, su borde engrosado en rosco pero sin el resalte anular característico del tipo A y con perfiles similares sin que se adviertan diferencias cronológicas evidentes entre el Middle y Late Style como defendía Goggin (1960). La núm. 73 , con borde con menor engrosamiento podría ser un síntoma tardío ( $2^{\mathrm{a}} 1 / 2 \mathrm{~s}$. XVIII) aunque la núm. 74, de igual datación porta el borde engrosado usual. Con similar escepticismo se expresan los Lister (1987: 211).

Otra diferencia formal aducida por Goggin para el tipo B: perfiles redondeados para el estilo medio (s. 1570-1780) y de hombro recto inclinado con quiebro marcado hacia el cuerpo ovoide para el estilo tardío (1780-1850), se confirma básicamente como tendencia pero dentro de las fechas del estilo medio, único repertorio que poseemos. El perfil redondeado es el primero (Martin, 1979: 280) y se mantiene hasta el final (núm. 67/72) y el perfil angulado, difícil de adscribir a veces, aparecería más tarde (núm. 71, med. s. XVIII).

Cierta diferencia cronológica se advierte en su factura, más descuidada y tosca en las variantes tardías, a veces con vedrío interior no cubriente. El tipo $B$ aparece frecuentemente con vedrío interior en tonos melados o blanco sucio; también puede portar marcas incisas o impresas en el hombro.

El sistema de cierre se puede reconstruir a partir de los tapones de corcho recuperados in situ en las Atarazanas y los restos de cuero que, cubriendo la boca y atados al cuello, se conservan en el ejemplar del Museum of International Folk Art de Santa Fé, New Mexico (Lister y Lister, 1987: fig. 123, d)

Las observaciones realizadas en la metrópoli sevillana sobre los envases fechados en bóvedas matizarían las fechas de aparición hasta ahora defendidas para los tipos A, (fines del s. XV en vez de 1580) y B (ca. 1550 en vez de 1580) y que han sido extraídas tan sólo de los datos arqueológicos americanos.

Tipo C: (núm. 75 a 78) También coincidente con el C de Goggin en las series de tamaño mayor, se distingue solamente por la forma apuntada del sector inferior del cuerpo. Las fechas recogidas hasta ahora en bóvedas oscilan desde el s. XVII a principios del s. XVIII. Estas fechas serían coincidentes con 
ejemplares recuperados en los pecios americanos del Atocha (1622), Conde de Tolosa y Guadalupe (1724) (James, 1985) y Plymouth en Inglaterra (Allan y Barber, 1992: fig. 3:12). Lister y Lister (1981: fig. 5,c) publican una botija que debe pertenecer a este tipo de base apuntada procedente de bóvedas de la Capilla del Sagrario de Sevilla de la primera mitad del s. XVII.

Tipo D: (núm. 79,80) Tipo muy escaso, se distingue fácilmente por su escasa capacidad y base especialmente apuntada. Su forma es tan singular que aún no se ha definido su posible uso o contenido, a veces interpretadas como antorchas (Jimenez Barrientos, 1982). Goggin las clasifica como estilo tardío tipo D, activo desde 1780 en adelante, coincidente por tanto con nuestro hallazgo de San Telmo de la $2^{\mathrm{a}}$ $1 / 2$ del s. XVIII y con algún ejemplar venezolano, quizás fechado por bibliografía (Duarte y Fernández, 1980: 114). En cualquier caso parece que la tendencia a apuntar la parte inferior de las botijas , tipos C y $\mathrm{D}$, es tardía.

Tipo E: (núm. 81 a 83) Este tipo sería nuevo con respecto a la clasificación de Goggin. Se distingue por su tamaño menor, semejante en el cuerpo al tipo B tardío, de hombro recto inclinado pero con la boca en rosco con resalte anular como los tipo mayores ( $\mathrm{A}$ y $\mathrm{C}$ ) y base cóncava con pezón o casi plana. Se dan tanto sin vidriar como con vedrío verde tinta a veces con matices turquesa por su mezcla con blanco (verde malaquita). Su fecha sería típica del s. XVIII, aunque disponemos de ejemplos del s. XVII, sin mayor precisión. El empleo del verde, escaso en general, y su base plana hacen pensar en la adaptación de los envases tradicionales de transporte en una versión de mayor lujo relacionado con un contenido de uso doméstico de menor consumo que el aceite o para uso doméstico como aceitera pero en ámbitos locales, no ultramarinos. Una versión similar en el tipo A y de la misma datación lo tenemos en el núm. 64 .

Tipo F: (núm. 84 a 87) Lo presentamos dentro de las series de botijas por sus características formales, similares en todo al tipo E pero con asa. Vidriadas igualmente en verde tinta por ambas superficies, a veces en verde malaquita, hemos hallado en las bóvedas de Las Atarazanas tres tamaños de la serie con hombros y otra variante, esférica con superficie especialmente marcada con las huellas del torno, agallonada, y base con solero.

Tipo bastante común en las casas sevillanas actuales, donde se denomina «aceitera», es considerado objeto de especial raigambre local; sus límites tipológicos consisten en la variedad de tamaños en las dos series, la de hombros (núm. 84-86) que a veces existe con dos asas y la esférica (núm. 87). Esta, muy abundante, se produce en Sevilla hasta el s. XX (Seseña, 1991: 173) e incluso nuestros días como objeto decorativo o adoptado por otros centros de producción, como Lucena (Córdoba) donde se denomina «Perula», para guardar aceite -que recuerda al término del s. XVI «botija perulera»-o Andújar (Jaén) donde se la denomina «Porrón de aguardiente» (Ministerio, 1981: fig. 88, 165).

Tipo G: (núm. 88) Solo disponemos de un ejemplar, incompleto, para aislar un tipo con el cuerpo de las series precedentes, E y F, sin vidriar, pero con cuello alargado y dos asas robustas. Su boca no debe ser engrosada sino delgada y abierta, quizás como la que presenta el núm. 171 de nuestra colección. Como variante esférica podría citarse una de la col. Folch de Barcelona, denominada «cantimplora» y fechada, no sabemos si correctamente, en el s. XVII (Sanchez Cortegana, 1992:14).

Los tres últimos tipos de botijas ( $\mathrm{E}, \mathrm{F}$ y $\mathrm{G}$ ) que ahora presentamos no fueron incluidos por Goggin ni por otros autores americanos de lo que cabría deducir que no fueron usadas para el comercio americano. Curiosamente estas variantes son tardías dentro del s. XVIII cuando Sevilla pierde el monopolio comercial con Indias. Estas variantes bien podrían significar una reacción de las industrias locales trianeras por readaptarse a las nuevas circunstancias creando estos tipos aceiteros de semilujo para usos locales. 
Hemos incluido una serie de variantes tipológicas que aparecen reflejadas en los documentos históricos, en los que se encuentran palabras diferentes para designar piezas de distinta capacidad y destinadas a contener mercancías de variada naturaleza. La correspondencia entre el destino prioritario ultramarino de unos recipientes llamados «botijas» en las citas documentales y la producción masiva de estas piezas en Sevilla desde el siglo XVI es evidente, pero la correspondencia entre términos históricos tales como botija perulera, botijuela, e incluso jarras y la variante de botija a la que se hace referencia es compleja, razón por la cual hemos englobado los distintos tipos bajo la sola denominación de «botijas», nombre que aún pervive. Goggin (1960: 3-5; 1968:228), ante la dificultad de decantarse por los diferentes términos usados las englobó también bajo un mismo nombre genérico, el de «olive jars», «jarras de aceite», en clara referencia a su contenido principal, opción exitosa en EEUU (Deagan, 1987:31) que nos parece discutible, dada la variedad de productos a los que estos recipientes sirvieron de contenedores ${ }^{28}$. Otros investigadores norteamericanos como los Lister (1976: 85-86) se han decantado inicialmente por el término «tinaja» que tiene para nosotros connotaciones de almacenamiento más que de transporte, además de no aparecer más que esporádicamente en las listas de los fletes para Indias. Más adelante estos mismos autores (1987:211) se refieren a estas piezas como «ánforas», «botijas peruleras» u «olive jars».

Ante la gran variedad en los tamaños de las piezas que componen cada tipo y la consecuente dificultad que ello supone para medir sus capacidades, hemos de concluir con otros autores (Lister y Lister, 1987:132133) que de haber existido alguna legislación sobre las medidas de las botijas éstas no se cumplieron, quedando el mayor o menor ajuste de las piezas a las medidas de capacidad vigentes relegadas a la habilidad del alfarero para sacar tamaños homogéneos por su propia experiencia y pericia artesanal.

Los productos a los que las botijas sirvieron de contenedores pueden conocerse a través de las listas de fletes que con destino a América partían del puerto de Sevilla. Entre ellos figuran aceitunas, vinagre, garbanzos, alcaparras, habas, miel, pescado, arroz, harina, jabón... Pero el destino principal de las botijas fue sin duda el transporte de vino y aceite para las Indias, productos cuyo cultivo fue muy pronto prohibido en América por decreto real. La demanda de vino y aceite experimentó un fuerte incremento hacia mediados del siglo XVI, coincidiendo con un marcado aumento de la producción de botijas, según deducimos de su predominio en los rellenos cerámicos.

La amplia dispersión de las botijas se encuentra siempre asociada a zonas portuarias, evidenciando su adaptabilidad para el transporte marítimo y su escasa operatividad en rutas terrestres. Conocemos ejemplares como los aquí recogidos en Irlanda, Inglaterra, Italia, Flandes, Francia, Norte de Africa y sobre todo, en el área Antillana, Caribeña y Golfo de México en América, en donde su hallazgo es muy frecuente. Desde 1960 varios autores (Goggin, 1960:31; Lister y Lister, 1987:165) han expresado sus hipótesis acerca de un origen sevillano de las botijas, aseveración que hoy podemos ratificar sin ninguna duda gracias a la información contenida en las bóvedas..$^{29} \mathrm{Las}$ formas que componen el «Late Style», a las que se presuponía un origen español múltiple e incluso americano (Goggin, 1970:31; Fairbanks, 1972:145-146) se producían en Sevilla. Cabe la posibilidad, no obstante, de que también desde otros puertos españoles se enviaran botijas tras la pérdida del monopolio comercial del puerto sevillano.

28. Tanto Goggin (1960:3-5) como Fairbanks (1973:144) y Martin (1979:282) exponen su preferencias por el término castellano «botijas» pero finalmente se deciden por el empleo de la denominación inglesa genérica «olive jars».

29. Resulta prácticamente absurdo que en 1993 se ratifique científicamente a partir de este trabajo la producción sevillana de las botijas lo que es de dominio público como también lo es su dispersión entre la sociedad sevillana entre la que es usual disponer de varias botijas en sus casas, procedentes de las cámaras antihumedad halladas en la ciudad. 
A América fue trasmitida también la técnica edilicia del aligeramiento de bóvedas y el embotijado (Goggin, 1960:6, plate 1; Fairbanks, 1972:144; Deagan, 1987:32), aunque no sabemos si en estos casos se emplearon piezas usadas o piezas con defecto de cocción. A esta última posibilidad parecen apuntar los fletes de botijas vacías que continuamente se enviaron a Indias durante el s. XVI (Lister y Lister, 1987: Apéndice 2).

JARRAS COMERCIALES. (núm. 89, 90, 144)

Utilizamos el término «jarra» en el apartado de transporte por su frecuente uso en la documentación histórica aunque somos conscientes de la dificultad que encierra la adscripción de una forma a esa denominación. Las escasas formas que aquí hemos asociado a este término no se corresponden a las abundantes referencias de la terminología histórica (Gestoso, 1903: 99).

El núm. 90, procedente de Las Atarazanas, es claramente foráneo de Sevilla por sus características de paredes finas, barro rojo intenso y depurado. Aparecieron varios cientos de ellas sin defecto de cocción y con descamaciones del barro por su alto contenido en sal. Entendemos que se trata de un envase llegado al puerto de Sevilla con un contenido quizás de conserva de fuerte sabor que hiciera desaconsejable su reutilización en otros ambientes una vez vacíos. Publicamos esta forma de mediados del s. XVIII con el fin de recabar información de la misma. Formas cercanas, aunque no conocemos sus características de pasta, podrían ser las denominadas «baluster jars» o jarras abalaustradas de North Devon, Inglaterra, de dimensiones similares, aunque solo conocemos sus formas del s. XVII (Allan y Barber, 1992: núm. 53,54)

\section{GRUPO DOMÉSTICO. 1. DOMÉSTICO GENERAL}

\section{CÁNTAROS. (núm. 91 a 101)}

Recipientes de cuerpo panzudo, perfil cóncavo en la mitad inferior y una sola asa. En algunos ejemplares de los tipos núm. 91,95 y 98 se han hallado sellos de alfarero estampillados. ${ }^{30}$

El uso doméstico es tan evidente como variado, incluyendo el transporte de agua desde las fuentes públicas a las casas, o de leche. El número de cántaros es elevado dentro del total de piezas de bóvedas y representan una gran variedad de formas. Destacamos las series de Sevilla (núm. 91/93 y 95/94) que representan los cántaros de azacán (aguadores) grandes, de arroba o 12 litros y pequeños, de media arroba o 6 litros. Este hecho parece ser extensivo a otras localidades como Marchena (núm. 96/97) o Carmona donde se citan en sus dos tamaños, grandes y pequeños, en el s. XVI (González Jiménez, 1972: 166).

Las series de Sevilla denotan un cambio formal desde los ejemplares de los ss. XV-XVI a los de ss. XVII-XVIII, más rechonchos (núm. 98,100), el primero exacto a los representados en la pintura sevillana del s. XVII (Seseña, 1991). Las asas salen del borde mismo de la boca en acodo simple. Los de Marchena presentan unas bocas finas y molduradas como distintivo local y panzas mas bajas que los sevillanos. El de Carmona ${ }^{31}$ es especialmente elegante con el cuerpo y boca marcadamente agallonados y base cóncava.

30. Los sellos encontrados en las formas 91 y 95 reproducen un esquema simplificado de la Giralda. Es la primera vez que se hallan estos cántaros sellados de acuerdo a la normativa municipal cuya existencia ya advirtiera Gestoso (1903: 102). Sobre el tema específico de los sellos preparamos un artículo independiente.

31. Conocemos otros ejemplares de Carmona de diferente forma y cronologías que publicaremos en otra ocasión. 
LEBRILLOS. 32 (núm. 102 a 111, 134)

Forma muy andaluza, su variedad formal es grande, sobre todo en tamaño. Muy bien conocidos en excavaciones, generalmente exhiben algún motivo decorativo, desde una simple impresión de cordón en el labio a una variedad de líneas incisas horizontales, rectas u onduladas. Algunos ejemplares presentan vedrío interior y exterior en el labio; posiblemente su estado final sería el vidriado, pero no hay que olvidar que la mayoría de las piezas estudiadas presentan defectos de primera cocción, por lo que nunca llegaron a recibirlo.

Son piezas bien representadas en el conjunto de materiales de bóvedas, en las que aparecen fragmentadas para calzar los restantes vasos en los rellenos. El vedrío suele ser verde desde el s. XV reservando el melado para ejemplares con decoraciones en manganeso, menos frecuentes. En momentos tardíos se decoran con fondo blanco y motivos lineales sencillos en verde o conjuntos policromos en los s. XVIII-XIX (Pleguezuelo, 1985: núm. 34,36,91,92)

Los ejemplos de Marchena presentan sus peculiaridades que los diferencian de las series sevillanas. El conservado de Carmona (núm. 134) también es más vertical y profundo que los sevillanos.

Los lebrillos, de múltiples tamaños, constituían el recipiente doméstico por excelencia con multiplicidad de usos hasta momentos recientes: lavado de ropas y vajillas (a menudo embutidos en poyetes de ladrillo en cocinas y lavaderos), preparación de comidas (masas, aliños, etc), calentar agua al sol, aseo personal, etc.

BACINES. (núm. 112 a 116, 122 a 124, 130)

Recipientes robustos con dos amplias asas para facilitar el vaciado. Generalmente se presentan melados al interior y parcialmente al exterior, y pueden mostrar líneas incisas horizontales o, como en el caso del núm.60, aplicaciones plásticas de cordones o costillas verticales paralelos. Este caso, sin vidriar en el que presentamos, lo conocemos con vedrío blanco con las costillas en verde en otros contextos de La Cartuja. El tipo se sigue utilizando en ámbitos rurales, como Lucena, Ubeda o Níjar (Ministerio, 1981: 94, 171, 282). El núm. 130, de forma similar pero sin asas podría ser un bacín aunque no es seguro. Su número dentro del conjunto de bóvedas es reducido y su uso, higiénico.

Un segundo grupo (núm. 122 a 124), mas tardío, se asocia formalmente a los bacines (núm. 116) pero no portan asas y su base no ensancha, detalles que los aleja de los requerimientos de los bacines tradicionales. Por otro lado están decorados en vidriado con temas vegetales y animales, paralelas y cadenetas en azul oscuro (azul cobalto con manganeso, «azul triana») y verde sobre blanco. El borde porta comas en azul en la variante figurada y trazos verdes sobre blanco en la simple.

Su decoración es la típica de tradición trianera de los ss. XVIII y XIX. Estos estilos fueron clasificados por Goggin (1968:201) como «Triana Simple» (núm.123) o «Triana Polícromo» (núm. 122, 124); Deagan (1987:93-95) los clasifica como «bacines sin asa, azul y verde» para los ejemplares americanos que data de forma correcta a partir de mediados del $\mathrm{s}$. XVIII ${ }^{33}$.

32. Algunos autores norteamericanos confunden la traducción al español del término designado para nombrar a estas piezas; es frecuente que traduzcan el término inglés «basin» por el español «bacín» al referirse a los lebrillos, cuando la correspondencia inglesa de «bacín» se establece con el término «chamber pot» (Skowroneck, 1982: 254).

33. A este respecto recordamos los bacines fabricados por Pickman en La Cartuja desde 1840 en loza de china, similares a estos, sin asa y con tapadera. Realmente se trata de la versión industrial a molde del bacín tradicional modernizando su aspecto con el nuevo concepto de lo higiénico expresado en el color blanco. 
En América son de aparición frecuente los bacines verdes en las colonias españolas estando presentes tan sólo en el s. XVI cuando en Sevilla aparecen melados (Deagan, 1987:48-49). También aparecen en Qsar es-Seghir en los s. XV-XVI (Redman, 1980:254).

JARRÓN. (núm. 117)

Recipiente único dentro de la colección, su función debió ser decorativa para interior o exterior, no sabemos si con vedrío. Esta forma del s. XV podría vincular su origen, como una versión simplificada, de las tinajas estampilladas almohades y mudéjares, tan comunes en Sevilla donde se fabricaron con profusión (Pleguezuelo, 1992: 184). ${ }^{34}$

HUCHA. (núm. 118)

También denominada «alcancía»; tan solo disponemos de un ejemplar en todas las colecciones. La alcancía es de tradición islámica ${ }^{35}$ y se fabrica hasta nuestros días.

MACETAS: (núm. 119 a 121)

Similar a algunas orzas, se puede distinguir por sus labios abiertos en dos pestañas conformando decoración de cadenetas mediante digitaciones y sin vedrío. El detalle decorativo es fundamental, ya que no se presenta más que en este tipo, completado por el ejemplar 121 que conserva el agujero basal. Hoy día existen macetas historiadas similares.

\section{GRUPO DOMÉSTICO. 2. DESPENSA}

QUESERAS ¿?: (núm. 125 a 134)

Su uso pudo ser la conservación de quesos, según deducimos de paralelos etnográficos, aunque en estos casos portan usualmente pequeñas asas (Ministerio, 1981: 43, 151, 169, 269) siendo difícil precisar esta función para algunos ejemplares. Se puede tratar una vez más de bacines sin asa (p. ej. núm. 130, de Marchena). Otro ejemplar de Carmona (núm. 134) podría ser igualmente un lebrillo profundo, diferente del sevillano, como ya indicamos. También algunos podrían ser barreños para uso de animales en corral. Ninguno de ellos presenta vedrío.

La asociación de bacines clásicos con asa (núm. 112, 113, 114 y 115) con formas semejantes sin asa $(125,126$ y 128) en los mismos conjuntos (A, B y F) induce claramente a pensar que éstos últimos no son bacines. Quizás el borde más corto y horizontal que se observa en ellos sea matiz diferenciador. De la misma forma, el conjunto de Marchena (J) presenta la serie 129 a 132 de vasos similares y con bordes alargados e inclinados por lo que es más difícil decantarse por la disyuntiva bacín/quesera para su adscripción.

34. Si bien el término «tinaja» es el usado para los ejemplares lujosos estampillados almohades, creemos que no es válido para momentos bajomedievales y cristianos. Recuérdese que para los muy lujosos nazaríes, de la misma forma, se usa el término «jarrón», mas apropiado para un uso decorativo y no de contención.

35. En la misma Cartuja hemos recuperado un ejemplar completo de los testares almohades. 
CÁNTARAS. (núm. 135,136)

Recipientes para contener líquidos como los cántaros pero dotados de dos o más asas. Aparecen menos representadas que aquellos y su variedad formal se reduce a los dos tipos recogidos. Ninguna de ellas presenta decoración ni vedrío.

ORZAS. (núm. 137 a 143, 145, 146, 148 a 150)

Recipientes de cuerpos amplios, de gran diversidad de tamaños, generalmente sin asas, bocas más o menos abiertas para recibir tapaderas o cierre amarrado. No suelen presentar vedrío, aunque en su estado final muchos de ellos debieron llevarlo para impermeabilizar sus interiores y hacerlos más adecuados a la conservación de ciertos productos alimenticios. Tal es el caso de la serie 148 a 150 de Las Atarazanas, la primera en bizcocho y las menores con vedrío interior y exterior parcial blanco sucio con trazos verdes.

Su representación numérica dentro del conjunto de las bóvedas es considerable, al igual que su variedad formal. Las orzas de Carmona (núm. 145 y 146) portan asas formando una serie aparte. De la serie tardía con asas atrofiadas conocemos un ejemplar del Museo Arqueológico de Sevilla portando una fecha similar a la de Las Atarazanas (1752) en la panza (Pleguezuelo, 1985:88) De estas series proceden las típicas orzas trianeras de los ss. XIX y XX (Ministerio, 1981: 55).

\section{GRUPO DOMÉSTICO. 3. MESA}

Este subgrupo está, por lo general, menos representado proporcionalmente debido a que sus formas contribuían en menor medida al aligeramiento de las bóvedas frente a otros recipientes de tamaño mayor. No obstante disponemos de un conjunto más que excelente de las bóvedas más antiguas de La Cartuja con datación anterior al fenómeno colonial. El incremento de vasijas comerciales que ello provocó genera mayor monotonía en los registros. Muchos de los vasos del siglo XV y comienzos del XVI aquí representados eran de uso general en la sociedad por lo que debieron perpetuarse en sus correspondencias funcionales de los ss. XVII y XVIII, en formas muy similares a estas tardomedievales. Es por ello que para el estudio de estas piezas hay que recurrir a otros tipos de registros arqueológicos, entre los que destacan los pozos negros; el material de estas series rescatado de los pozos de las celdas de monjes y legos de la Cartuja de Sevilla es del más alto interés y complementa la tipología que ofrecen las bóvedas.

\section{FUENTES. (núm. 151 a 156)}

Piezas de ascendencia islámica, aparecen totalmente vidriadas en melado y sin vedrío, aunque el resultado final en su elaboración debió ser la aplicación del mismo. Algunas presentan decoración de ondulaciones incisas en el borde, o líneas pintadas en manganeso, según diseños de tradición islámica (núm. 152). Su uso en la mesa debió ser colectivo, como recipiente para servir o presentar la comida.

Es interesante contar con fechas precisas para estas series frecuentes también en los registros arqueológicos. Las núm. 151 y 152 son claramente productos intermedios entre los ataifores islámicos y las escudillas y platos con los que se van asemejando por su pérdida de diámetro. Esto ha sido advertido en Lisboa donde aparecen tipos muy semejantes (Torres, 1991: fig. 14) con similar cronología. 
JARROS. (núm. 157 a 171)

Recipientes de uso colectivo para el servicio de agua o vino en las mesas. Se distinguen artificialmente de las jarras por la presencia de una sola asa, aunque el criterio puede no ser compartido. Algunos tienen pico esbozado para facilitar el vertido y a veces vedrío melado al interior y parcialmente al exterior.

En los tamaños mayores y en general para toda la serie se distinguen de los cántaros por sus vientres menos panzudos, cuellos mas largos que generan asas mas largas y parte inferior del cuerpo convexo frente a los perfiles cóncavos de los cántaros. La colección se centra en los ss. XV y XVI de Sevilla con bastante similitud a las encontradas, sin vidriar, en Beja de hacia 1500 donde igualmente son consideradas formas comunes en el Alentejo y Algarve portugueses perpetuándose hasta la alfarería tradicional del s. XIX (Figueira, 1991: 568, 570). El único ejemplo tardío, de Las Atarazanas (núm. 171), presenta afinidades formales con botellas centroeuropeas de licores destilados. El núm. 170, de Carmona, se asemeja estrechamente al cántaro de la localidad (núm. 99).

JARRAS. (núm. 172 a 175)

Piezas que presentan dos o más asas a diferencia de los jarros; en algunas se distingue una decoración plástica a base de series paralelas y onduladas peinadas, hoyitos (núm. 157) y pencas o apéndices aplicados. No debieron ir vidriados con objeto de refrescar el agua por filtrado y evaporación.

Su uso es igualmente colectivo. Su número es menor que el de los jarros y la variedad formal se halla en perfecta proporción con su escasez. Las dos formas (núm. 173 y 174) pueden haber sido empleadas como «jarras de cortesía», según paralelos etnográficos: ${ }^{36}$ jarras como éstas, cuidadas y decoradas, se colocaban en los recibidores de las casas como objeto no sólo decorativo sino también funcional, con la idea de ofrecer agua a los visitantes.

La núm. 175, incompleta, podría también asociarse a las botijas esféricas y a las de doble asa y cuello alargado (tipos F y G).

JARRITOS. (núm. 176 a 182)

Piezas similares a los jarros aunque de menor tamaño, para atender a un uso individual de mesa. A excepción del núm. 90 todos los jarritos tienen vedrío melado por el interior y en casi la totalidad del exterior. El núm. 181 es un caso único de hallazgo de una pieza con decoración vidriada en tonos azul cobalto y morado manganeso sobre fondo blanco.

Esta gran colección, tan sólo de los ss. XV y XVI, corresponde a la loza basta y se complementaría con las series vidriadas en blanco no presentes aquí. Excepción sería el núm. 181 de fines del s. XV que correspondería por su técnica decorativa a las series de mayólica que en terminología norteamericana se las conoce como «Isabela Polychrome» (Deagan, 1987: 58) y que recientemente se las denomina acertadamente «Seville Blue and Purple» (Ray: 1987) asumido y traducido al español por «Azul y Morada» sevillana. De esta jarrita, forma extraña en esta serie, disponemos de un paralelo cercano también de finales del s. XV en Qsar es-Seghir (Sinopoli, e.p. fig. 3:14)

36. Esta sugerente idea nos fue dada por P. Mora autor de los dibujos. 
JARRITAS. (núm. 183 a 188)

De uso individual y pequeñas, como los jarritos, se diferencian de éstos en la existencia de dos o más asas. Las hay vidriadas en verde o sin vidriar. Más historiadas que los jarritos, presentan varias decoraciones, escalonando el cuerpo, distinguiendo el labio como para sorber directamente u otras como series horizontales incisas a peine, hoyitos y aplicaciones.

Representan una de las versiones evolucionadas de las jarritas de dos asas islámicas para refrescar y beber agua de gran tradición en Andalucía. Todas ellas corresponden al s. XV siendo muy difícil su hallazgo en bóvedas posteriores por las causas generales aducidas para otras series. Con posterioridad se las ha conocido como «tallas»o «alcarrazas» (Gestoso, 1903: 134)

PLATOS. (núm. 189, 190)

Piezas de tradición cristiana cuya implantación corresponde a los gustos que generalizan el uso del recipiente individual en el que se incluyen las escudillas. Su hallazgo en bóvedas es muy esporádico siendo muy "común en otros ámbitos; los dos ejemplares conocidos son del $\mathrm{s}$. $\mathrm{XV}$, uno de ellos melado con decoración de círculos y trazos en manganeso de tradición morisca. El estado final de todas estas piezas debió ser vidriado.

ESCUDILLAS. (núm. 191 a 194)

Son versiones reducidas de formas islámicas para uso individual en el mundo cristiano. Todas debieron ser vidriadas; en estos casos corresponden a las series bastas de tradición morisca en melado liso o incluyendo resabios epigráficos. Como ocurre con otras piezas de vajilla de mesa en las bóvedas sólo encontramos escasos ejemplares de tradición morisca, por lo que habría que recurrir a otros tipos de registro arqueológico para completar la tipología de las escudillas producidas en Sevilla.

\section{GRUPO DOMÉSTICO. 4. COCINA}

Este subgrupo atiende especialmente a los vasos cerámicos fabricados para procesar alimentos al fuego. Usualmente utilizan desde la Edad Media barros rojos con inclusiones de cuarzos y otras y por lo general se presentan con vedrío transparente al interior y parcialmente al exterior. También se incluyen aquellos otros vasos que se asocian en el procesamiento de alimentos.

OLLAS. (núm. 147, 195 a 202)

Caso prácticamente único, muchos ejemplares aparecen reutilizados en las bóvedas, ennegrecidas por el uso. Por lo demás, son formas frecuentes en los rellenos de bóvedas. Se corresponden fielmente con las ollas de tradición islámica a base de formas repetidas hasta prácticamente nuestros días. La colección cuenta con una serie representativa de los ss. XV y XVI y dos ejemplos, diferentes, de Carmona.

ANAFES. (núm. 203, 204)

Series clásicas de tradición islámica para contener brasas y cocinar sobre ellos por lo que no llevan vedrío. Su presencia en las bóvedas es muy rara, reduciéndose a ejemplos tardíos (ss. XVII-XVIII) de Sevilla y Carmona. 
CAZUELAS. (núm. 205 a 207)

REDOMAS. (núm. 208,209)

Recipientes vidriados en forma de jarritos de cuello estrecho, alargado y boca en forma de piquera; barros claros y vedrío melado. Su número es escaso en la colección, de los ss. XV y XVI, y servirían como aceiteras.

MORTEROS. (núm. 210 a 212)

De factura basta con desgrasantes gruesos; sólidos por su función no portan vedrío en los ejemplos rescatados aunque usualmente lo llevaron según conocemos por fragmentos recogidos en excavación que se presentan verdes al exterior y blancos al interior.

Tenemos muy pocos ejemplares de este tipo, pues aparecen muy rara vez en bóvedas. El tipo de La Cartuja (s. XV) es el clásico que se encuentra en las colonias americanas (South et al. 1988: 277), portuguesas, donde curiosamente no están vidriados (Redman, 1980: 254) y otros puntos portugueses como Silves (Varela y Varela, 1991: 471).

\section{OBSERVACIONES}

Aparte de las múltiples observaciones realizadas a lo lago del texto precedente exponemos a continuación otras de orden general.

a. Los conjuntos de loza basta de Triana, Marchena y Carmona denotan con claridad una tradición musulmana en muchos de sus tipos, complementada por otros típicamente cristianos. Los primeros consisten en aquellos tipos básicos que incluso se han resuelto de forma parecida en culturas anteriores como la romana.

Las tinajas, tinas, cangilones, formas azucareras, lebrillos, jarrón, hucha, fuentes, ollas, cazuelas, anafes son formas en las que se advierte una ascendencia desde el repertorio musulmán, aparte lógicamente del vidriado. Igual se podría hablar de las jarritas de doble asa aunque existen otros tipos cristianos más próximos a los musulmanes.

Los albarelos, dolias, cantimploras, botijas, bacines, queseras, orzas, jarros, jarritos, platos, escudillas, redomas o morteros se asocian en mayor medida a costumbres cristianas derivadas de otras tradiciones comerciales o diferentes modos de aseo personal, almacenamiento e ingestión de productos fermentados prohibidos por el Corán, como quesos, escabeches, salmueras o vino y la colación individual frente a la colectiva.

b. Existe una diferencia clara en la diversidad formal aparecida en las bóvedas del s. XV y principios del s. XVI con respecto a las posteriores. El grupo primero cuenta con amplios repertorios de cerámica común mientras que el segundo es más monótono. A modo de ejemplo, las bóvedas A y $\mathrm{B}$, registran 41 y 49 formas diferentes con sólo un envase industrial. Por el contrario, en las bóvedas sevillanas de los ss. XVII y XVIII más de la mitad de las formas presentes son botijas y otros envases industriales.

Por ello, nuestro objetivo de utilizar los rellenos de bóvedas para recomponer lo más ampliamente posible el conjunto de cerámicas comunes utilizadas por una colectividad ha sido más exitoso en el grupo primitivo que en el tardío. Es evidente que formas comunes como jarros, jarritas, jarritos, cantimploras, 
morteros, etc. se siguieron haciendo en Triana y con formas no muy diferentes a las de siglos anteriores pero no disponemos de ellas en las colecciones estudiadas. Por ello, sería necesario contrastar las tipologías existentes con otros registros de excavación en medio urbano, especialmente en los talleres de Triana, para completar las de los siglos XVII y XVIII.

A partir de la colonización de América los talleres de Triana producen masivamente botijas como envases para el comercio ultramarino. Ello motiva que se cuente con un alto potencial de desechos en esta familia con respecto a otras cerámicas comunes de menor producción. Esta circunstancia se refleja en una mayor oferta en número y en un tamaño estándar para su reuso en la construcción.

No en vano es a partir de mediados del s. XVI, momento en el que se comienza a disponer de tantos excedentes de desechos, cuando se inicia la costumbre masiva del embotijado. Esta circunstancia de mejoras en la calidad de vida se ha podido comprobar en la Cartuja donde se utilizó el embotijado en las celdas de monjes y en el área del altar de determinadas capillas, donde el oficiante está mayor tiempo.

Existen conjuntos tardíos en que no solamente las botijas representan más de la mitad del repertorio formal sino que suponían el $80690 \%$ del registro total siendo una anécdota la presencia de otras variantes en el conjunto.

Si separamos en los registros de bóvedas por un lado los tipos comunes y por otro los envases comerciales dispondríamos de los siguientes recuentos formales para los diferentes siglos:

Sevilla.

s. XV: 87 tipos comunes. 3 tipos de envases.

s. XVI: 50 tipos comunes. 11 tipos de envases.

s. XVII: 14 tipos comunes. 16 tipos de envases.

s. XVIII: 12 tipos comunes. 20 tipos de envases.

Marchena.

s. XV-XVI: 25 tipos comunes. ${ }^{37}$

Carmona.

s: XVII 8 tipos comunes.

s. XVIII: 3 tipos comunes.

En ellos se advierte claramente la disminución del repertorio formal de lozas comunes de acuerdo con el tiempo lo cual evidentemente no se corresponde con la realidad. Un factor corrector es el aumento proporcional de tipos diferentes de envases comerciales a lo largo del tiempo utilizados para el aligeramiento.

En cualquier caso, creemos que es una suerte disponer de conjuntos bastante representativos de los siglos XV y XVI, etapa donde la arqueología tiene mayor campo de acción que en siglos posteriores. Por otro lado, las abundantes colecciones de botijas suponen un elemento de gran importancia para complementar desde la arqueología una parcela importante de la historia de Sevilla.

El único conjunto tardío no sevillano de que disponemos, San José de Carmona, ( $2^{\mathrm{a}}$ mitad s. XVII), ofrece un repertorio más amplio por bóveda que sus coetáneos de Sevilla debido a que esta localidad no se vio afectada por la industria masiva del envase ultramarino.

37. Al tiempo que redactamos este trabajo hemos tenido conocimiento de la existencia de varias formas mas procedentes del mismo conjunto no recogidas en la colección aquí presentada. 
c. Cuestión importante es intentar definir la diversidad formal que produce un taller alfarero, su repertorio. Para ello disponemos de la información de cada bóveda diferenciada, partiendo de la hipótesis de que es un taller el contratado para abastecer una bóveda o, mejor, las cubiertas de un edificio. No obstante esta hipótesis choca con la dificultad que entraña para un taller alfarero disponer de suficientes averías como para abastecer grandes obras que requieren un cubicaje importante.

Las fuentes documentales también aportan elementos de juicio. Así, conocemos el ollero sevillano Diego Rodriguez, contratado para abastecer de cacharros a la bóveda de la Capilla de la Antigua de la Catedral y conocemos su contenido en diversidad formal pero no en número, lo cual hubiera sido del máximo interés.

Por otro lado disponemos de la información brindada por el taller de F. N. Pisano e hijos, (1508-1560) parte de cuyos testares fueron excavados en 1987 (Lorenzo et al. 1990; Pleguezuelo, 1992a). Es el único testar excavado hasta la actualidad en Triana y nos interesa para contrastar la diversidad formal a la que se dedica un taller, aunque éste en particular puede que no sea muy representativo por el personaje tan peculiar que lo regentaba.

Lógicamente sería del máximo interés aportar la visualización de los diversos conjuntos excavados pero ello conllevaría un exceso de aparato gráfico para este artículo. No obstante es nuestro interés esbozar unas conclusiones de aquellos fenómenos generales que se puedan establecer en un primer momento.

Es obvio que todos los conjuntos de Sevilla representados pertenecen a talleres de olleros de «loza basta o labor áspera», denominados en otras localidades como Carmona, barreros, divididos en las especialidades de cantareros, tinajeros y tejeros ${ }^{38}$. Estas especializaciones alfareras se oponen a la más restringida de ollero de loza fina, de más escasa presencia o total ausencia en muchos centros alfareros y que no concurre en el abastecimiento de la construcción por los tamaños menores que producen.

Observaciones claras resultan de los conjuntos de Marchena, donde San Juan (E) ofrece claramente la producción típica de un «tinajero»: grandes vasos realizados mediante paleteado cuyo control exige una especialización concreta, unos hornos de mayor tamaño y un mercado especializado. Frente a esta producción netamente definida, el conjunto (J) de la misma Iglesia de San Juan es diferente por completo del anterior. Esta producción sería la asignable a un «cantarero», «del oficio de la rueda», respondiendo a la demanda de lozas bastas comunes de uso doméstico y agrícola: cántaros, cangilones, cantimploras, lebrillos, queseras, fuentes, morteros. Curiosamente existen varias formas que se repiten en varios tipos. Así, las cantimploras (47 y 51), lebrillos (107 a 109), queseras o bacines (129 a 132) y morteros (211 y 212 ) sugieren la posibilidad de que nos hallemos ante la producción de dos cantareros ya que sería complejo admitir una diversidad formal para tantos usos sin que haya diferencias llamativas de tamaños, tratamiento, etc.

Una producción de cantarero similar a la de Marchena vemos en Carmona (conjuntos $\mathrm{O}$ y $\mathrm{Q}$ ) donde se recogen aquellos vasos y útiles básicos de una localidad: cangilones, cantimploras, lebrillos, cántaros, orzas, anafes, etc. ${ }^{39}$

El caso de Sevilla es más complejo. Los conjuntos del s. XV y comienzos del s. XVI aportan similares colecciones a las de los pueblos comentados. No obstante observamos que se dan ciertos tipos cuya

38. Ordenanzas de Barreros de Carmona, hechas el 5 de Junio de 1559. El conocimiento de su texto lo debemos a M. González Jiménez quien las incluyó en su tesis doctoral y a quien agradecemos su amabilidad.

39. La producción tradicional de los barreros carmonenses, prácticamente extinguidos en la actualidad, constaba hasta hace pocos años de este repertorio rural que hemos definido. En los años 60 se describía así su producción: ...objetos de uso doméstico, o para el campo y construcción en general... dornillos, «lebrillos de barro solamente»...arcancías, «Alcancías», cántaros, macetas, canjilones de noria, tejas y otros objetos. (Méndez, 1974: 154) 
producción debió ser acaparada por Triana para el mercado más extenso de la ciudad de Sevilla y para su comercialización en otros núcleos. Nos referimos a la cantidad de jarros, jarritos y jarritas vidriados, bacines y lebrillos vidriados que acompañan a las producciones clásicas ya vistas de cangilones, cántaros, cantimploras, ollas, fuentes... También las jarras y jarritas finas para filtrar y refrescar agua aparecen en Triana.

La ciudad, aparte de su protagonismo de gran urbe con anterioridad a la colonización americana y su agresividad comercial debido al puerto, disponía de buenas canteras de barro y tradición alfarera. No todos los barros permiten la fabricación de productos finos o la adherencia del vedrío y en este detalle nada baladí debe basarse la profusión de formas de Triana, a las que habría que añadir las labores finas, mayólicas, etc. no presentes en las bóvedas. Triana no era el centro alfarero usual en cualquier núcleo de población sino un gran barrio alfarero con capacidad de acometer mayores retos productivos.

Es curioso observar la producción de La Cartuja (A, B) con respecto a la coetánea de San Isidoro (C): en ésta vemos el conjunto típico de un taller con el repertorio doméstico y agrícola: cangilones, comederos, tarros, cantimploras, cántaros, bacines, jarros, jarritos y jarritas sin vidriar para el agua, pero con variantes formales de sus homólogas de La Cartuja.

El taller de F.N. Pisano, a juzgar por sus testares, se impuso en Sevilla con gran agresividad comercial ya que produjo no sólo sus obras de arte, retablos de azulejos planos, colaboraciones con escultores sino azulejos de arista en gran cantidad, tejas vidriadas y vajillas (platos y escudillas) tanto meladas de tradición morisca cuanto de mayólica en diversas modalidades estilísticas. Claramente se trataba de un empresario que aglutinaba a diversos artífices de diversas especialidades en loza fina y otras labores de barro, pero el modelo debía reproducir a muchos talleres de loza basta en Triana. La producción del taller de Pisano marcaría por contraste la del ollero de loza fina frente a los olleros de basto representados por las producciones incluidas en este artículo cuya demanda, y no la otra, era requerida para la construcción.

El fenómeno comercial americano supone un reto sin igual para Sevilla. La necesidad de envases comerciales hubo de repercutir de forma importante en un gremio del que no conocemos detalles documentales. El conjunto I de La Cartuja exhibe la producción de un taller que se va especializando en los nuevos productos. Junto a cangilones, conejeras, cantimploras, cántaros, lebrillos u ollas típicas encontramos la colección de primeros envases para ultramar curiosamente asociados: las cantimploras comerciales (las primeras «botijas») en todas sus variantes (núm. 42,44 y 50) junto a las formas de azúcar (núm. 25) o la orza (núm. 142) que debió servir para envíos a América. Curiosamente observamos en este importante conjunto las cantimploras usuales y las adaptadas para comercio con mayor capacidad por su perfil esférico, nuevo diseño abocinado para la boca y vidriada. Igualmente existen dolias (núm. 33), lo cual nos indica que se trata de un ollero conectado con las redes comerciales tradicionales para quien abastecía de envases y que ahora exigen otros nuevos. Similares comentarios se pueden aplicar al conjunto D del Capítulo de La Cartuja y el F de La Catedral donde conviven las cantimploras usuales (núm. 49 y 41) con las comerciales (núm. 44, 50) y dolias (núm. 35 y 34) aparte de orzas (núm. 139 y 140, 141), posiblemente comerciales.

El conjunto $\mathrm{F}$ añade el interés de poder contrastar la demanda del Cabildo de jarros e cantaros para el aligeramiento de La Antigua y los envases que se han registrado: cangilones, dolias (ijarros, jarras?), cantimploras, cántaros, bacines, queseras y orzas. Aunque algunos de estos vasos tuvieran otra denominación en 1512, mas bien entendemos que el Cabildo se refiere genéricamente a la necesidad de los distintos tipos de cacharros que aportan los olleros para el aligeramiento de las bóvedas.

En pleno s. XVI y sobre todo con posterioridad asistimos a lo que debió ser una clara especialización y adaptación de los talleres. Las bóvedas $\mathrm{G}$ o $\mathrm{K}$, ofrecen exclusivamente tipos comerciales, botijas y conjuntos azucareros, aunque lo usual pudo ser el gran taller que producía botijas a gran escala 
combinándolas con otros productos bastos de gran demanda como cangilones y cántaros como vemos en La Trinidad (M) o Los Terceros $(\mathrm{N})$, en este caso acompañados de orzas, posiblemente comerciales (núm. $143,144)$.

El conjunto de San Luis $(\mathrm{P})$ no difiere en gran medida de los anteriores aunque hemos anotado que se incrementa la presencia de tipos de botijas al igual que en Las Atarazanas (S) lo cual añade un problema más. La diversidad formal de las botijas en estos conjuntos tendría que explicarse bien como el concurso de varios talleres con variantes tipológicas sin mayor trascendencia para el abastecimiento de loza quebrada o que en un mismo taller eran fabricados por distintos operarios diferentes variables de los tipos de envases. En cualquier caso es importante advertir que las variables no conllevan precisiones cronológicas y que solamente por la vía documental de encargos o la excavación de algún taller se podría resolver esta duda. No sería de extrañar que se tratara de varios talleres ya que estos estaban muy próximos, debiendo abastecer cada uno con sus averías los grandes conjuntos arquitectónicos que se realizaban en la Sevilla barroca y otras localidades probablemente.

La enorme variedad de botijas de Las Atarazanas, algunos de cuyos tipos hemos asociado con cambios de estrategias comerciales dirigidas a mercados interiores, se acompaña de un repertorio completo de bacines en sus dos versiones, simple y figurado polícromo, que tanto sirvieron para el mercado interior como para el americano.

d. Al igual que apunta en sus conclusiones Figueira Mestre (1991: 570) para la alfarería alentejana, tenemos que convenir que el conjunto de cerámicas comunes de la provincia de Sevilla de los siglos XV a XVIII comporta una fuerte y homogénea tradición que ha seguido vigente en su totalidad hasta el s. XIX según Figueira o hasta los años 60 según Seseña (1991) transformándose fuertemente con la «modernización» de España. Realmente se puede afirmar que la acusada tradición rural española, andaluza en general y sevillana en particular, por lo que atañe a este trabajo, ha permanecido vinculada a unos modos de producción y tecnologías prácticamente invariables en las Edades Moderna y Contemporánea hasta el maquinismo de los 60 y un reflejo de todo ello queda explicitado en la tradición alfarera y sus implicaciones.

\section{BIBLIOGRAFÍA}

ALLAN, J. and BARBER, J. (1992): «A Seventeenth-century pottery group from Kitto Institute, Plymouth.» Everiday and exotic pottery from Europe, c. 650-1900. Studies in honour of John G. Hurst, D. Gaimster and M. Redknap ed. Oxbow Books, Oxford: 225-245.

ALONSO DE LA SIERRA, J., LASSO DE LA VEGA, Mª G. (1982): «Tinajas Mudéjares del Museo Arqueológico de Sevilla: Tipología y Decoración.» En Homenaje a Conchita Fernandez Chicarro, Ministerio de Cultura, Madrid: 457-470.

AMIGUES, F., CRUSELLES, E., GONZÁLEZ-VILLAESCUSA, R., LERMA, V. En prensa: «Los envases cerámicos de Paterna/Manises y el Comercio Bajomedieval». V Colloque International de Céramique Médiévale en Méditerranée Occidentale. Rabat, 1991.

AMORES CARREDANO, F. (1992): «El programa de Intervención Arqueológica.» La Cartuja Recuperada. Sevilla 1986-1992, Junta de Andalucía, Consejería de Cultura y Medio Ambiente Sevilla: 41 60 
AMORES CARREDANO, F. y CHISVERT JIMÉNEZ, N. (1991): «Sevilla y América: Interpretación del hallazgo de un grupo de formas de azúcar del siglo XVI en la Cartuja de Santa María de las Cuevas (Sevilla)». Segundo Seminario Internacional La Caña de Azúcar en el Mediterráneo Occidental. (Motril, 1990). Granada: 163-182.

AMORES, F.; CHISVERT, N.; FUENTES, A.Mª .; LÓPEZ, J.; MORA, P. Y RUEDA, M. En prensa: «Una primera tipología de la cerámica común bajomedieval y moderna sevillana (ss.XV-XVII)». V Colloque International de Céramique Médiévale en Méditerranée Occidentale. Rabat, 1991.

AZNAR VALLEJO, E. y VIÑA BRITO, E. (1990): «El azúcar en Canarias.» Primer Seminario Internacional La Caña de Azúcar en Tiempos de los Grandes Descubrimientos, 1450-1550, (Motril, 1989). Granada: 173-188.

BASSEGODA NONELL, J. (1983): La Cerámica Popular en la Arquitectura Gótica. Barcelona.

BEAUDRY, M.; LONG, J.; MILLER, H.; NEIMAN, F. and STONE, G. (1988): «A vessel tipology for early Chesapeake ceramics: the Potomac Typological System.» Documentary Archaeology in the New World, New Directions in Archaeology, Beaudry, M. ed. Cambridge: 51-67.

CHILDS, W. R. En prensa: «Documentary Evidence for the Import of Spanish Pottery to England in the Later Middle Ages», Spanish Medieval Ceramics in Spain and the British Isles, BAR International Series.

COVARRUBIAS, S. de (1943): Tesoro de la Lengua Castellana. (ed. orig. 1611) Edit. Horta J.E. Barcelona

DEAGAN, K. (1987): Artifacts of the Spanish Colonies of Florida and the Caribbean, 1500-1800. Smithsonian Institution Press. Washington.

DUARTE, C. Y FERNANDEZ, $\mathrm{M}^{\mathrm{a}}$ L. (1980): La cerámica durante la época colonial venezolana, Armitano Editor, Caracas.

FAIRBANKS, Ch. H. (1973): «The Cultural Significance of Spanish Ceramics». Ceramics in America. The University Press of Virginia, Ian M.G. Quimby ed.: 141-173.

FIGUEIRA MESTRE, J. (1991): «Olaria medieval de Beja. Contribuicao para o seu estudo. A Cerâmica Medieval no Mediterrâneo Occidental, Lisboa, 1987: 565-574)

FRANCOVICH, R., GELICHI, S. (1986): «La ceramica spagnola in Toscana nell Bassomedioevo». Segundo Coloquio Internacional de Cerámica Medieval en el Mediterráneo Occidental, Madrid: 297313.

GESTOSO Y PÉREZ, J. (1903): Historia de los Barros Vidriados Sevillanos. Sevilla.

GISBERT SANTONJA, J. A. (1991): «En torno a la producción y elaboración de azúcar en las comarcas de la Safor-Valencia y la Marina Alta-Alicante. S.XIV-XIX. Arquitectura y evidencia arqueológica». Segundo Seminario Internacional La Caña de Azúcar en el Mediterráneo Occidental, (Motril, 1990). Granada: 211-272.

GOGGIN, J. M. (1960): The Spanish Olive Jars. An Introductory Study. Yale University Publications in Anthropology, $n^{\circ} 62$.

(1968): Spanish Majolica in the New World. Types of the Sixteenth to Eighteenth centuries. Yale University Publications in Anthropology, $\mathrm{n}^{\circ} 72$.

GONZÁLEZ JIMÉNEZ, M. (1972): Ordenanzas del Concejo de Carmona. Diputación Provincial de Sevilla.

GONZÁLEZ TASCON, I.; FERNÁNDEZ PÉREZ, J. (1990): «El azúcar en el Viejo Mundo. El impacto en su elaboración.» Primer Seminario Internacional La Caña de Azúcar en tiempos de los grandes descubrimientos, 1450-1550, (Motril, 1989). Granada: 99-130.

HURST, J.G. (1977): «Spanish Pottery Imported into Medieval Britain». Medieval Archaeology, Vol. 21: 68-105. 
JAMES, S. (1985): The analysis of the Conde de Tolosa and the Nuestra Señora de Guadalupe Olive Jar assemblage. M.A. thesis, Texas A\&M University, College Station.

JIMÉNEZ BARRIENTOS, J. C. (1982): «Un Grupo de Diecisiete Anforitas en el Museo Arqueológico Provincial de Sevilla». En Homenaje a Conchita Fernández Chicarro, Ministerio de Cultura, Madrid: 393-398.

LISTER, F., LISTER, R. (1976): A Descriptive Dictionary for 500 Years of Spanish- Tradition Ceramics (13th Through 18th Centuries). Special Publication Series, $\mathrm{n}^{\circ} 1$; The Society for Historical Archaeology. (1981): «The Recycled Pots and Potsherds of Spain». Historical Archaeology, vol. 15: 66-78. (1987): Andalusian ceramics in Spain and New Spain. The University of Arizona Press.

LLORENS ARTIGAS,J., CORREDOR-MATHEOS,J. (1970): Cerámica Popular Española. Barcelona.

LÓPEZ MORALES, H. (1990): «Orígenes de la caña de azúcar en Iberoamérica.» Primer Seminario Internacional La Caña de Azúcar en Tiempos de los Grandes Descubrimientos, 1450-1550, (Motril, 1989). Granada: 189-207.

LORENZO, J.; VERA, M.; ESCUDERO, J. (1990): «Intervención arqueológica en c/ Pureza, 44 de Sevilla», Anuario Arqueológico de Andalucía, 1987, Sevilla: 574-580.

LLUBIA, L. M. (1968): Cerámica Medieval Española. Barcelona.

MACCARI-POISSON, B.: (1991): «Contribution à l'etude des poteries du Haut-Moyen-Age: le Quartier Saint-Jean à Lyon (IXe-Xe siècles).» A Cerâmica Medieval no Mediterrâneo Ocidental, Lisboa, 1987: 147-160.

MARTÍN, C.J.M. (1979): «Spanish Armada Pottery». The International Journal of Nautical Archaeology and Underwater Exploration, 8.4: 279-302.

McEWAM, B.G. (1992): «The Role of Ceramics in Spain and Spanish America during the 16th Century». Historical Archaeology, vol. 26,1: 92-108.

MÉNDEZ ÁLVAREZ, C. (1974): La Cultura Popular de Carmona, Excma. Diputación Provincial de Sevilla, Sección Historia, 5. Sevilla

MINISTERIO DE CULTURA (1981): Cerámica Popular de Andalucía. Dirección General de Bellas Artes, Archivos y Bibliotecas.

MORALES, A., AMORES, F., CAMPOS, J.M., MORENO, M.T. Y VERA, M. (1987): «Análisis Histórico-Arqueológico de las Capillas de Santa María Magdalena y Santas Justa y Rufina de La Cartuja de Santa María de Las Cuevas. Sevilla» Anuario Arqueológico de Andalucía, 1986, t. III, Sevilla: 336-342.

MYERS, E.J., BLACKMAN, J. M. (1986): «Conical Plates of the Spanish-Moresque Tradition from Qsar Es-Seghir: Petrographic and Chemical Analyses». La Ceramica Medievale nel Mediterraneo Occidentale, Siena, 1984: 55-68.

MYERS, E.J., AMORES, F., OLIN, J. Y PLEGUEZUELO, A. (1992): «Compositional identification of Seville Majolica at overseas sites.» Historical Archaeology, vol 26:131-147.

PLATT, C., COLEMAN-SMITH, R. (1975): Excavations in Medieval Southampton, 1953-1969. Volume 2, The Finds. Leicester University Press.

PLEGUEZUELO, A. (1985): Cerámica de Triana (siglos XVI al XIX). Colección Artistas Plásticos, $\mathbf{n}^{\circ}$ 8. Caja Gral. de Ahorros de Granada.

(1992a): «Francisco Niculoso Pisano: datos arqueológicos.» Bolletino del Museo Internazionale delle Ceramiche in Faenza, fasc. III-IV: 171-191.

(1992b): «Tinaja Almohade», Catálogo de la exposición Andalucía y el Mediterráneo (Almería), Junta de Andalucía, Consejería de Cultura y Medio Ambiente: 184-185.

RAY, A. (1987): «Fifteenth century Spanish pottery: the blue and purple family», The Burlington Magazine, Mayo. 
REDMAN, Ch. (1979): «Description and Inference with the Late Medieval Pottery from Qsar Es-Seghir, Morocco». Bulletin of the Medieval Research Group, Vol.3, University of New York at Bingamton: 63-79.

(1980): «Late medieval ceramics from Qsar Es-Seghir.»La Céramique Médiévale en Mediterranée Occidentale, Valbonne, 1978. Paris: 251-263.

RÍO MORENO, J. del (1990): «Refinerías de azúcar en Sevilla, (s.XVI-XVII)». Primer Seminario Internacional La Caña de Azúcar en Tiempos de los Grandes Descubrimientos (1450-1550), (Motril, 1989). Granada: 131-156.

(1991): Los inicios de la agricultura europea en el Nuevo Mundo: 1492-1542, Asaja, Cajas Rurales de Sevilla y Huelva.

SÁNCHEZ CORTEGANA, J.Mª (1992): «Triana y América: las cerámicas que exportábamos en el s. XVI.» Buenaventura de Indias, vol. I, $\mathrm{n}^{\circ}$ 6. Sevilla: 7-17.

SÁNCHEZ SÁNCHEZ, J. Ma (1993): El comercio Cerámico entre Sevilla y América (1492-1600), Tesis doctoral inédita, Univ. Sevilla.

SASSOON, H. (1981): «Ceramics from the Wreck of a Portuguese Ship at Mombasa». Azania, Vol.XVI. SESEÑA, N. (1991): «Los Barros y Lozas que Pintó Velazquez.» Archivo Español de Arte, no 254, Madrid: 171-179.

SINOPOLI, C. En prensa: «The Blue-on-White Majolica of Qsar es-Seghir.» Qsar es-Seghir, vol. 2: The Portuguese Period, Ch. L. Redman, ed. Villes et Sites Archeologiques Morocaine, Rabat.

SOUTH, S., SKOWRONEK, R. K., JOHNSON, R., (1988): «Spanish Artifacts from Santa Elena». Anthropological Studies 7. Occasional Papers of the South Carolina Institute of Archaeology and Anthropology. University of South Carolina, Columbia.

TASSA GENERAL DE LOS PRECIOS A QUE SE HAN DE VENDER LAS MERCADERÍAS EN ESTA CIUDAD DE SEVILLA Y SU TIERRA;... (1627): mss. Biblioteca Central de la Universidad de Sevilla.

TORRES, Cl. (1990): «Um forno cerâmico dos seculos XV e XVI na cintura industrial de Lisboa». Fours de Potiers et "Testares» Médiévaux en Méditerranée Occidentale. Publications de la Casa de Velázquez, Série Archéologie, XIII, Madrid, 1990: 131-142.

(1991): «A industria do açucar nos alvores da espansao atlantica portuguesa». Segundo Seminario Internacional La Caña de azúcar en el Mediterráneo Occidental, (Motril, 1990). Granada: 183-210.

VARELA GOMES, M. Y VARELA GOMES, R. (1991): «Cerâmicas vidradas e esmaltadas, dos séculos XIV, XV e XVI, do Poco-cisterna de Silves.» A Cerâmica Medieval no Mediterrâneo Ocidental. Lisboa, 1987, Mértola: 457-490 

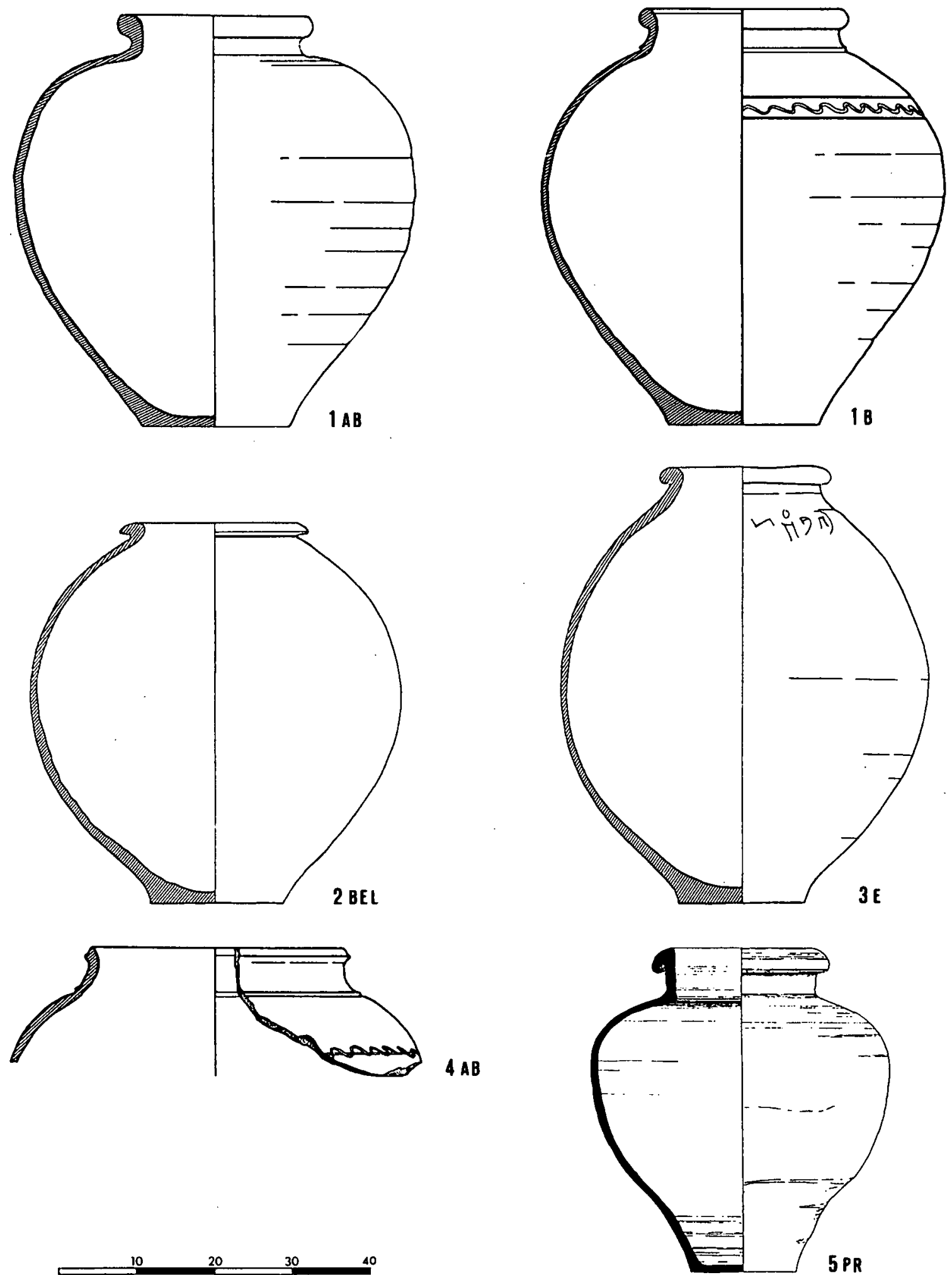

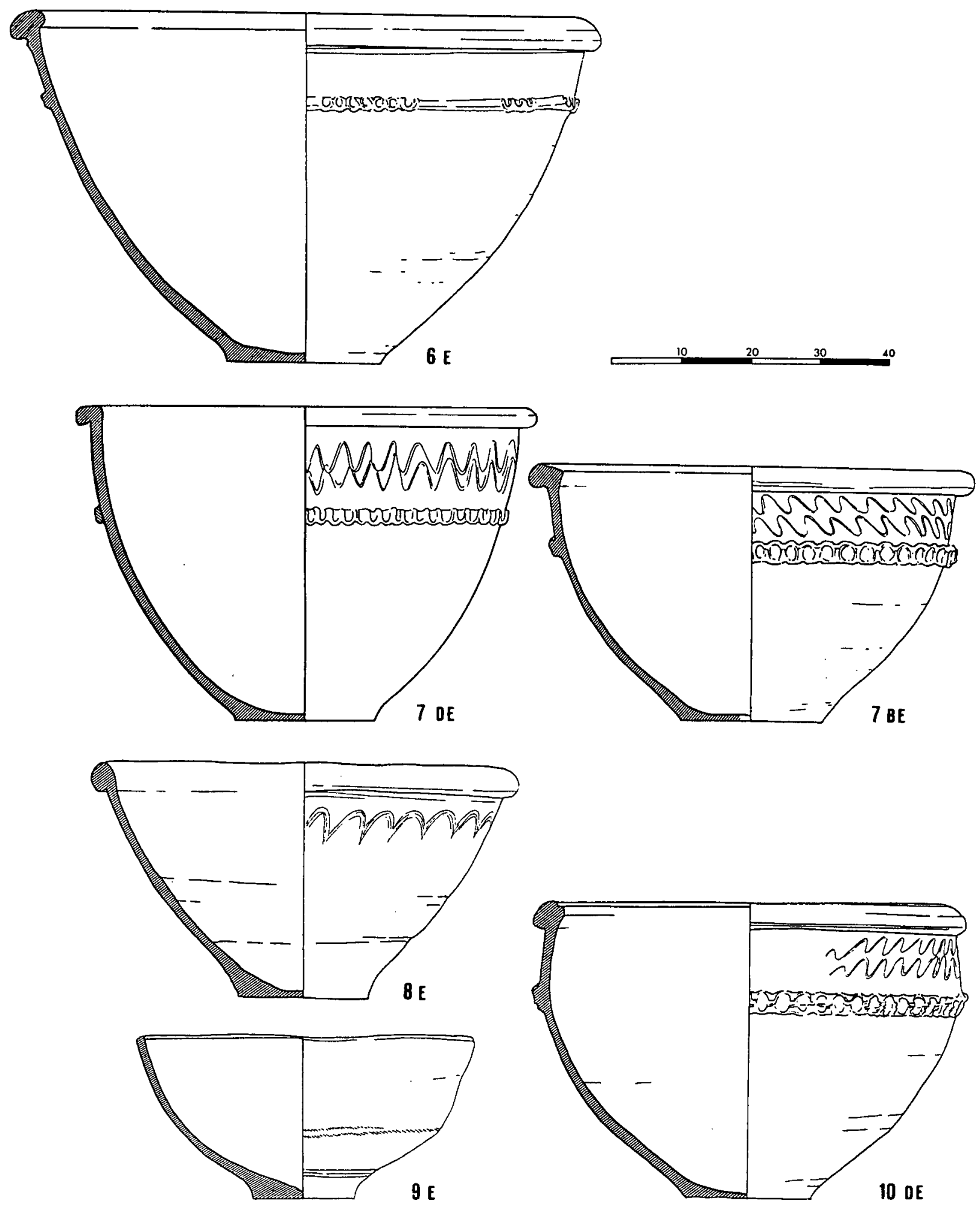

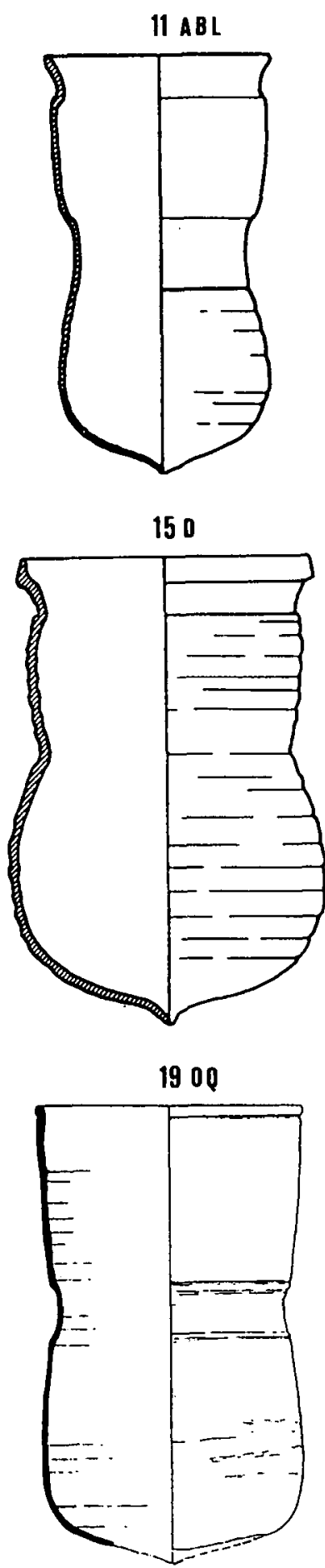
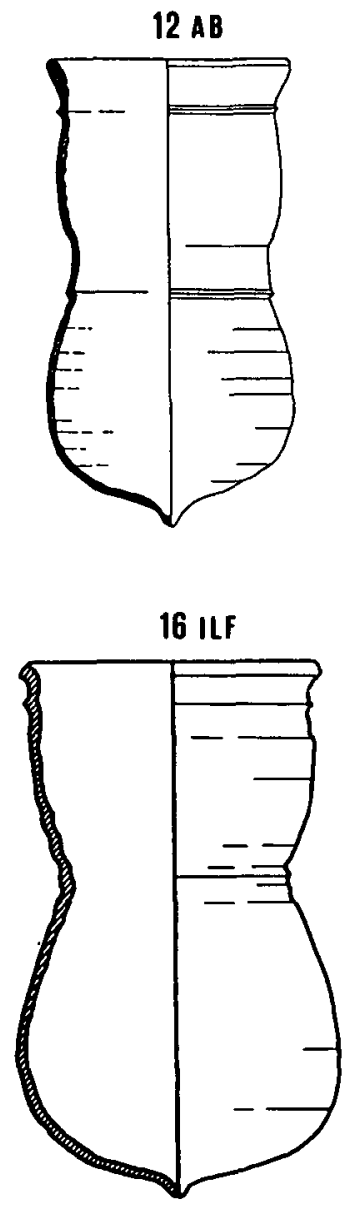

16 ILF

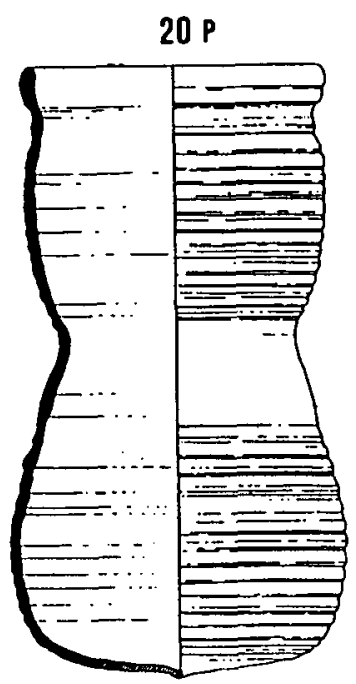

13 B

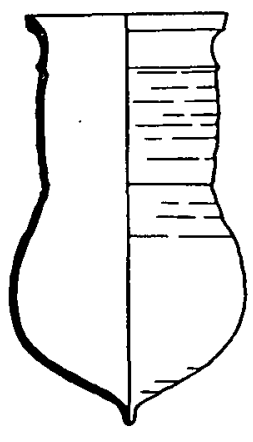

$17 \mathrm{~J}$

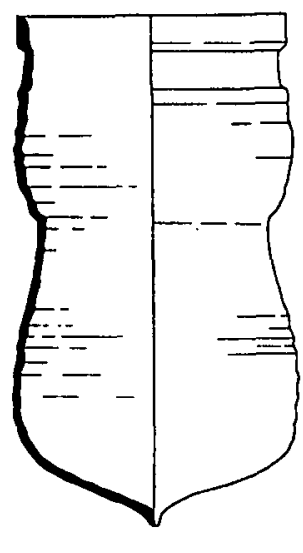

$21 \mathrm{P}$
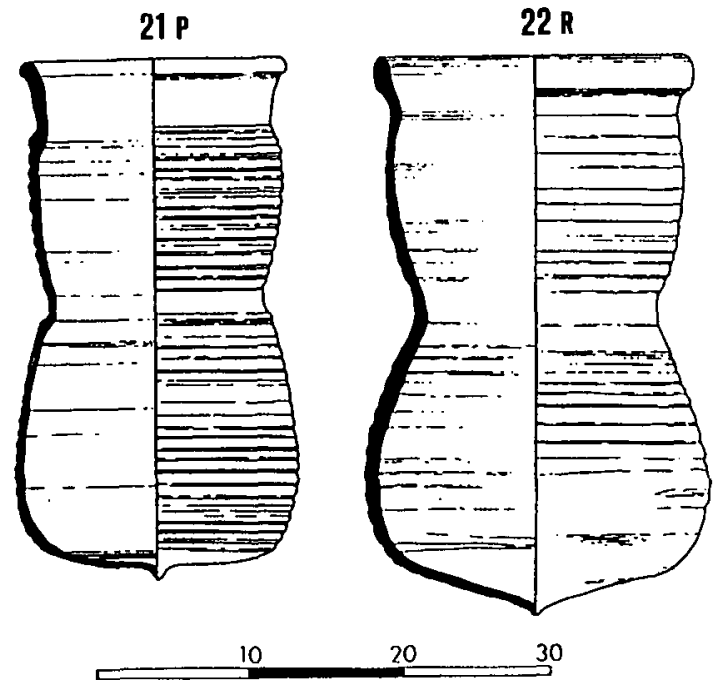

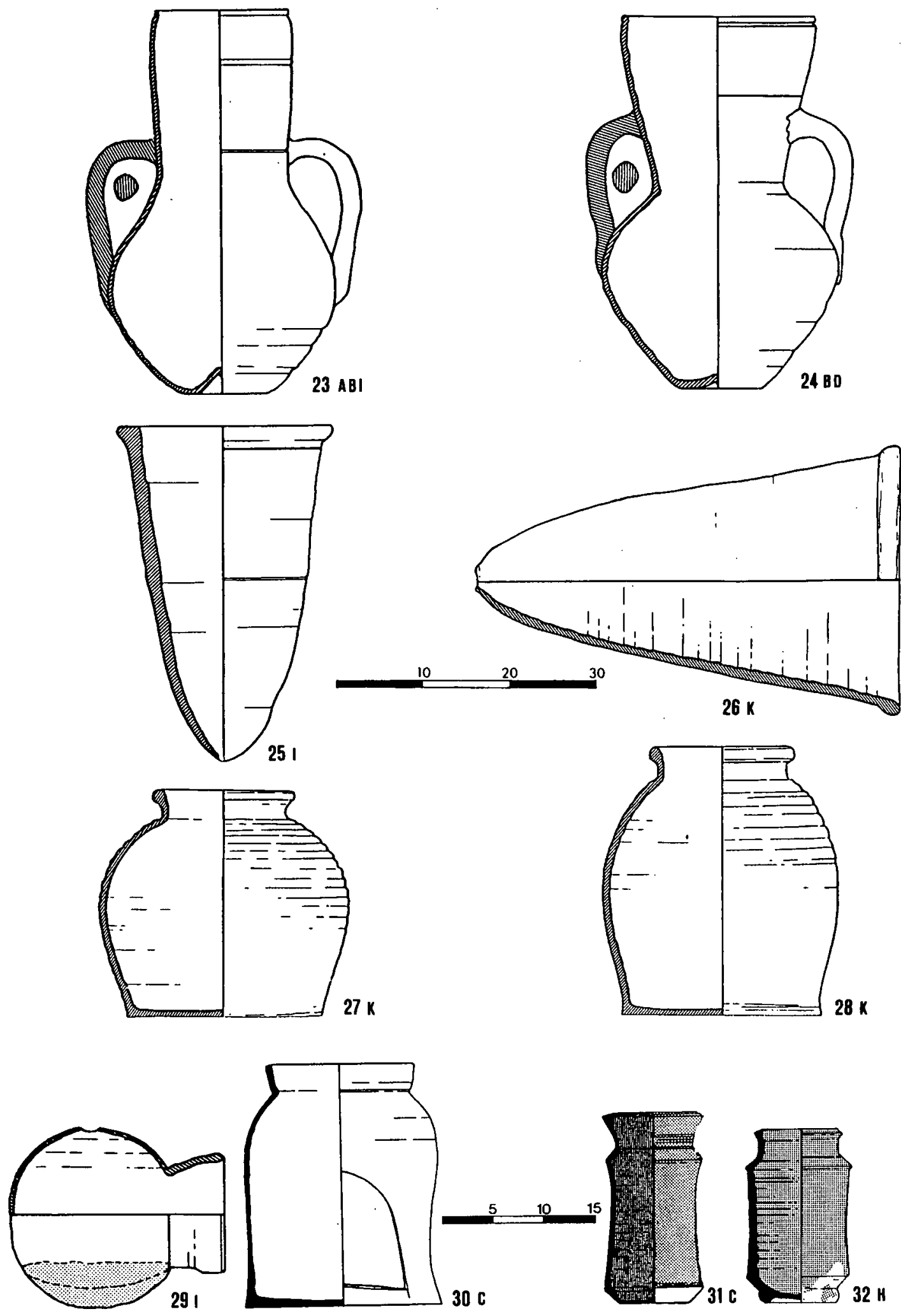

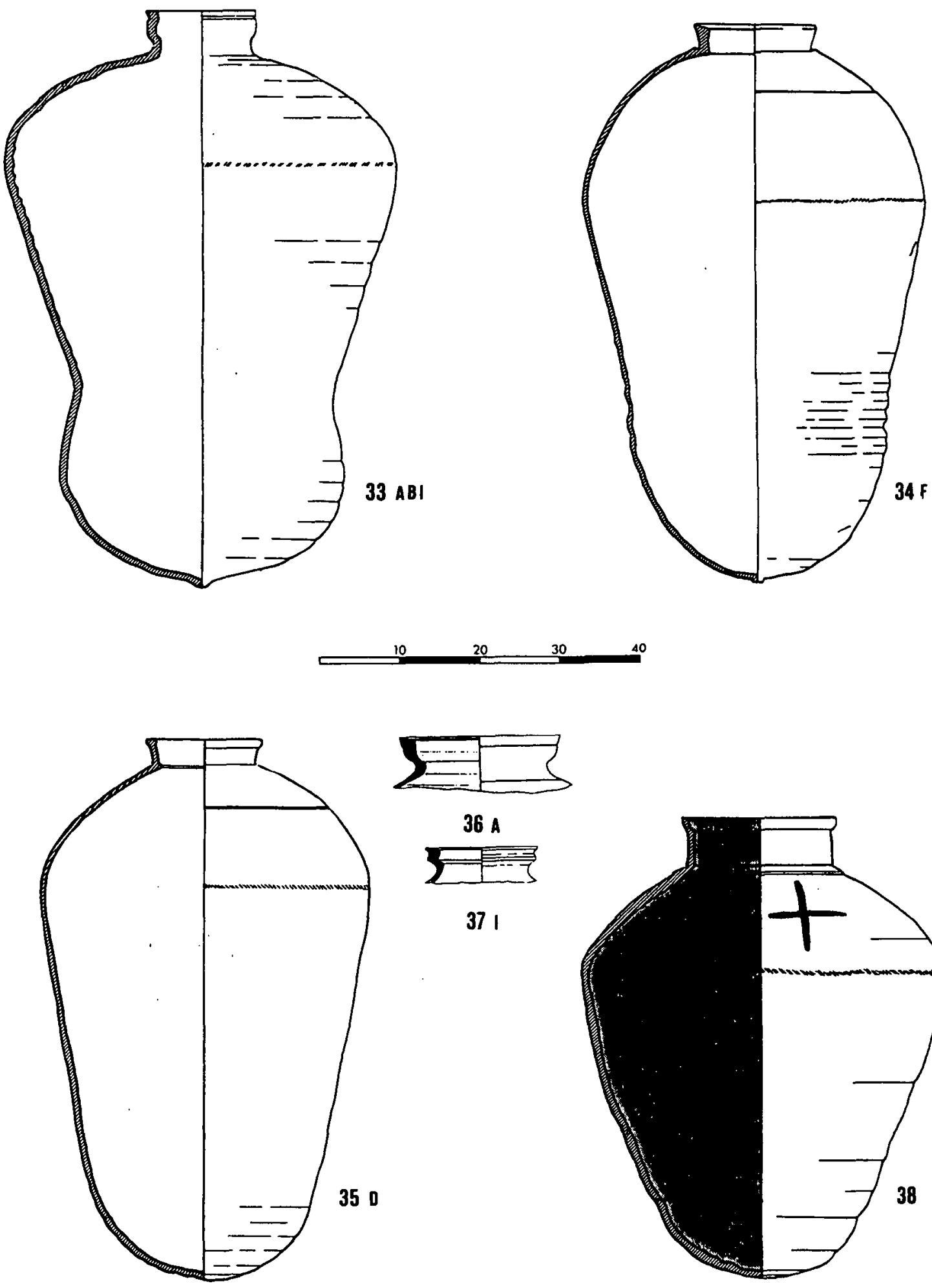

$36 \mathrm{~A}$

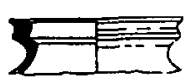

371

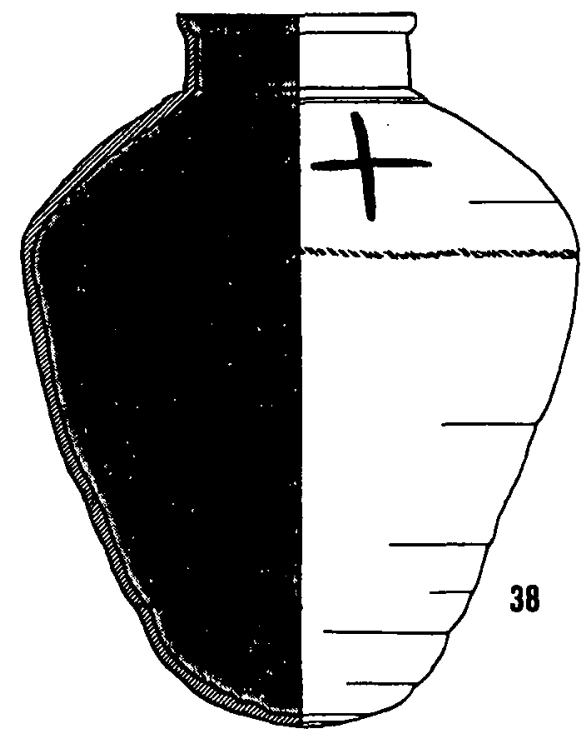



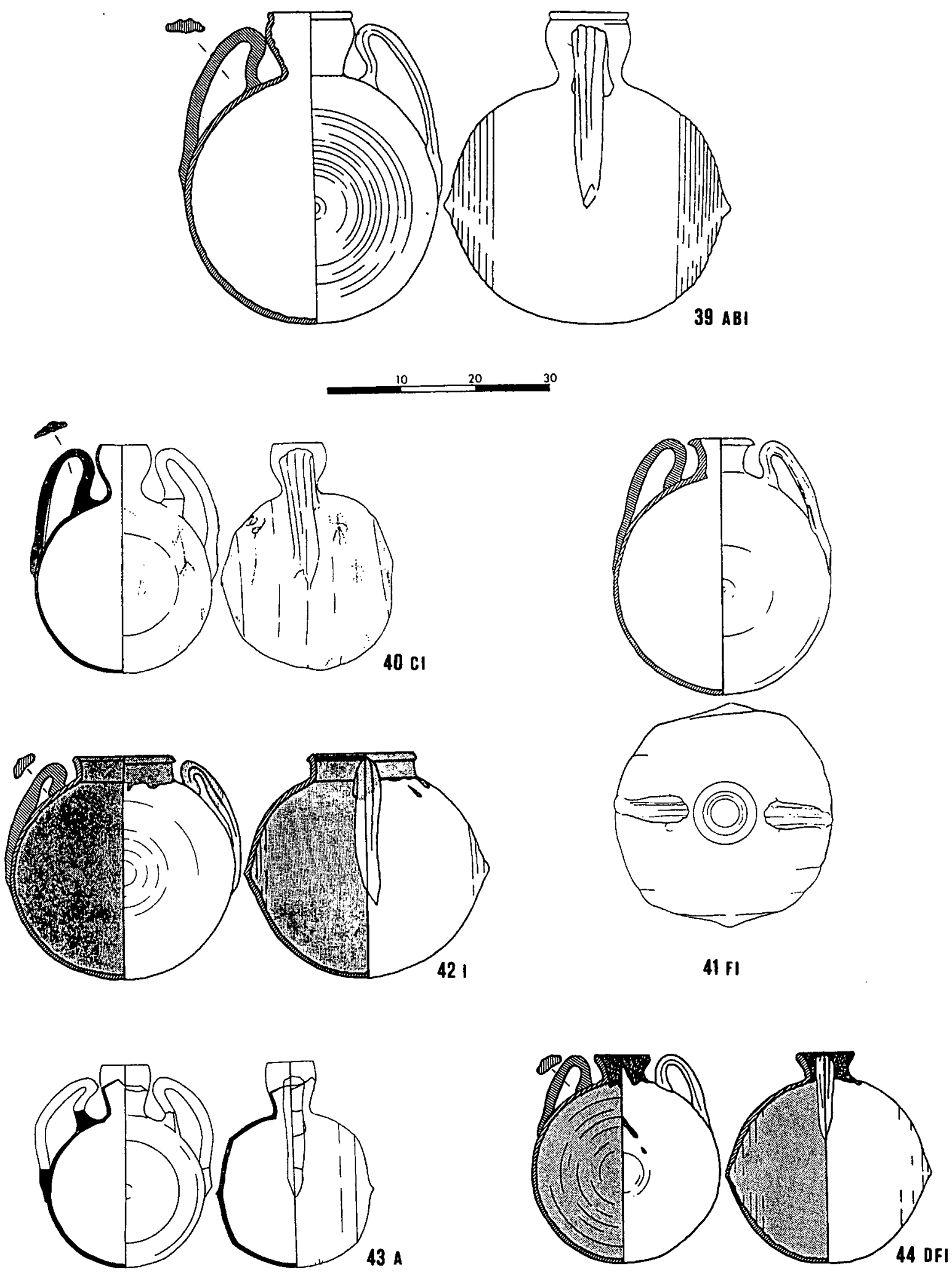

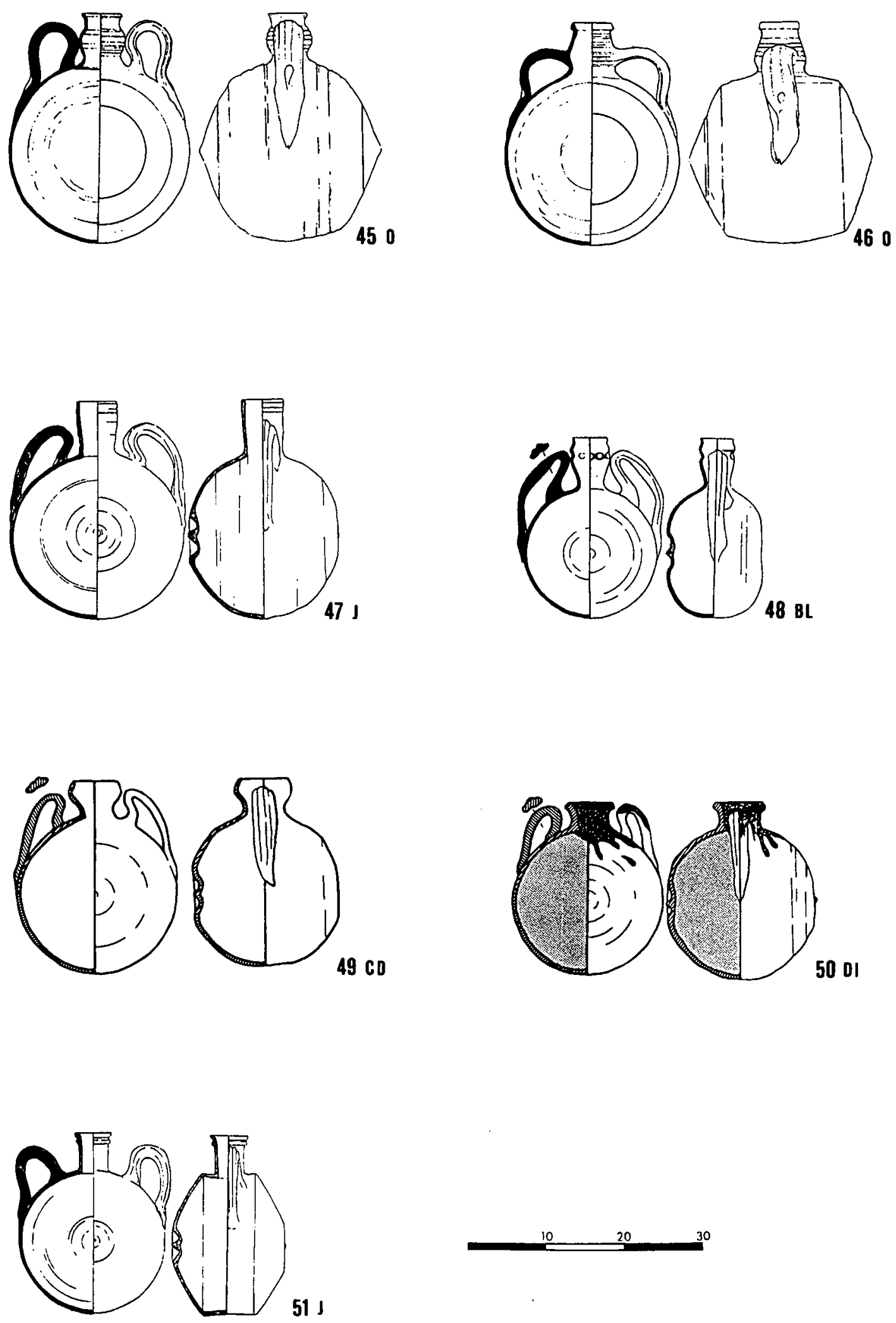

SPAL 2 (1993) 

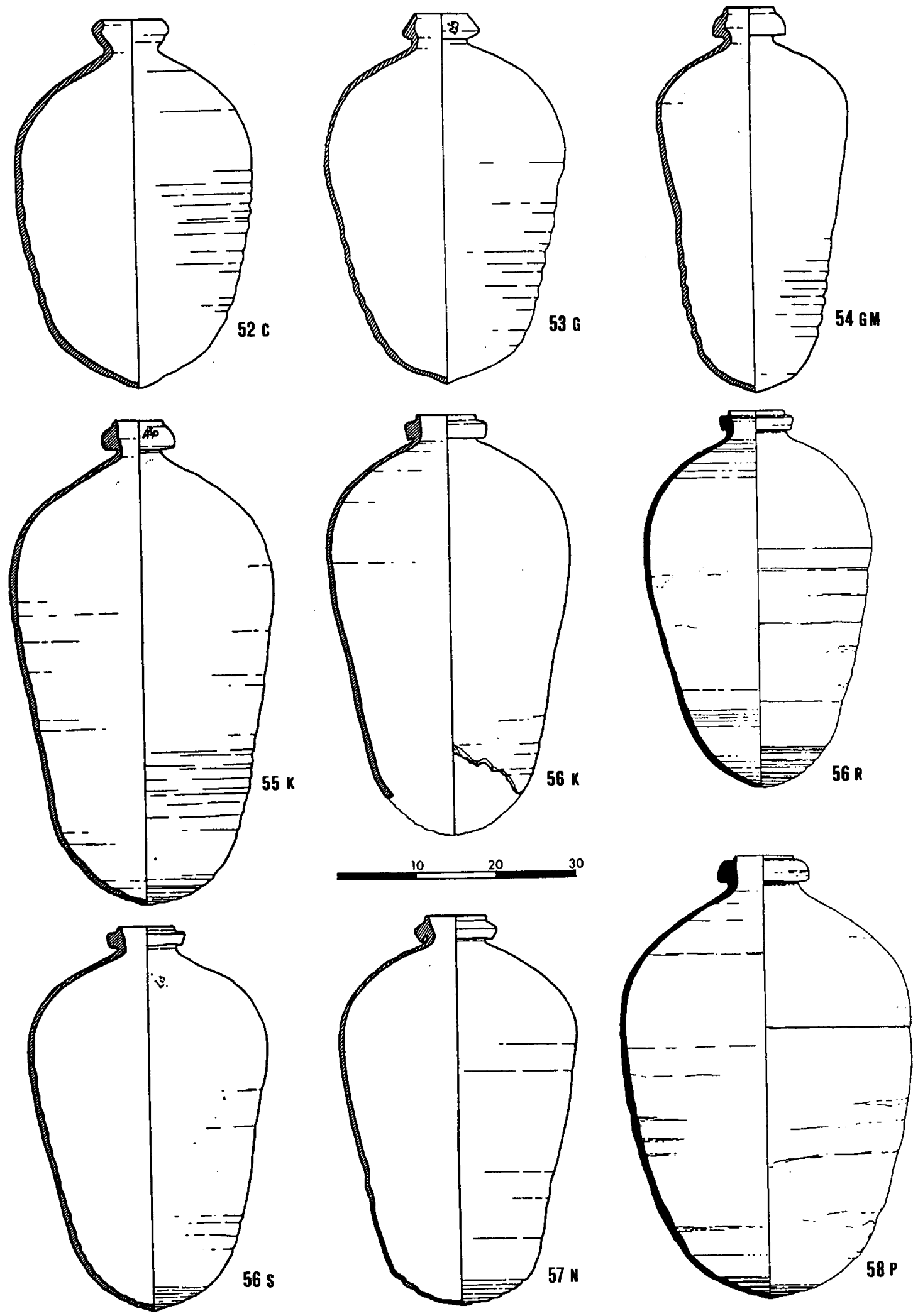

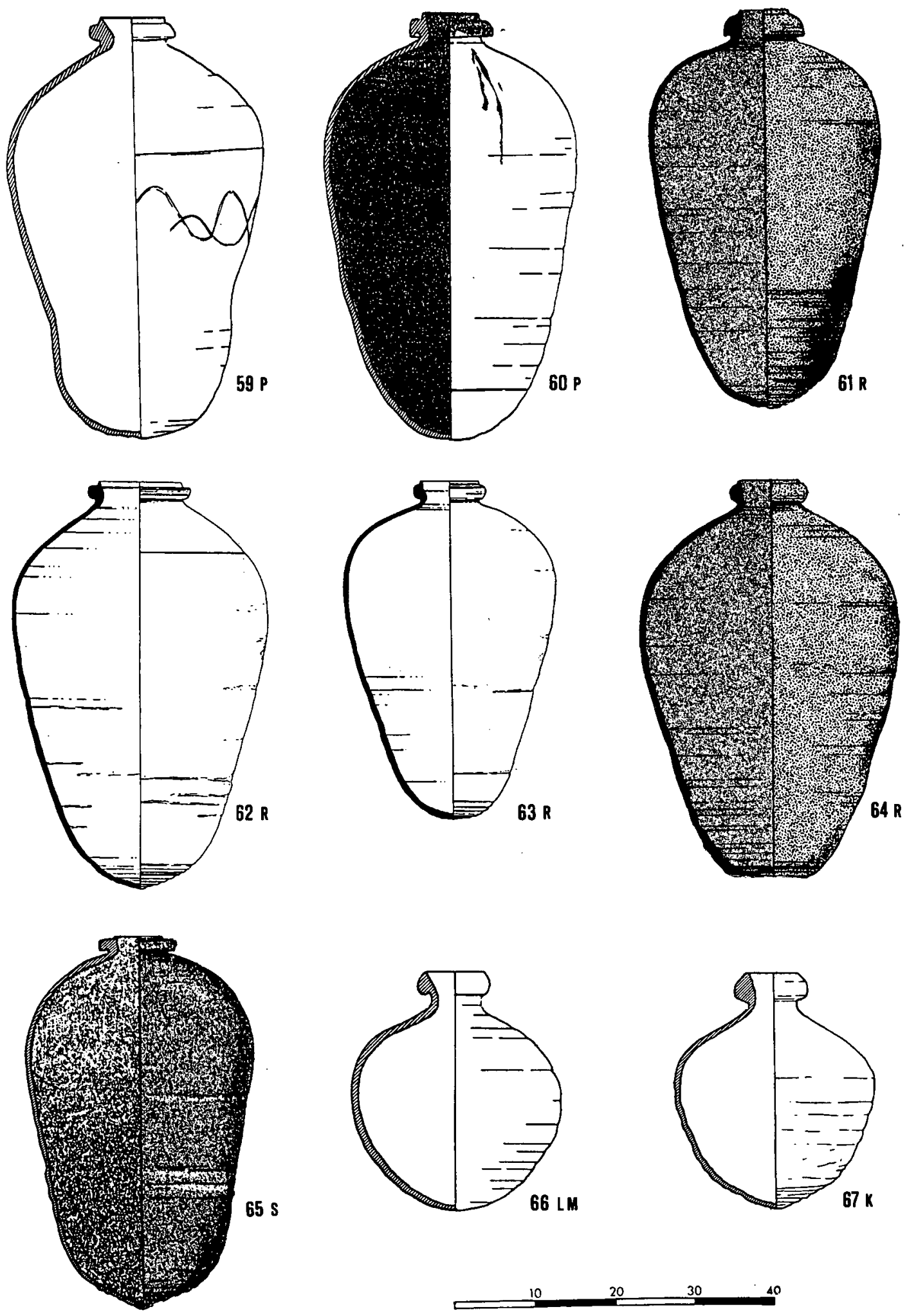

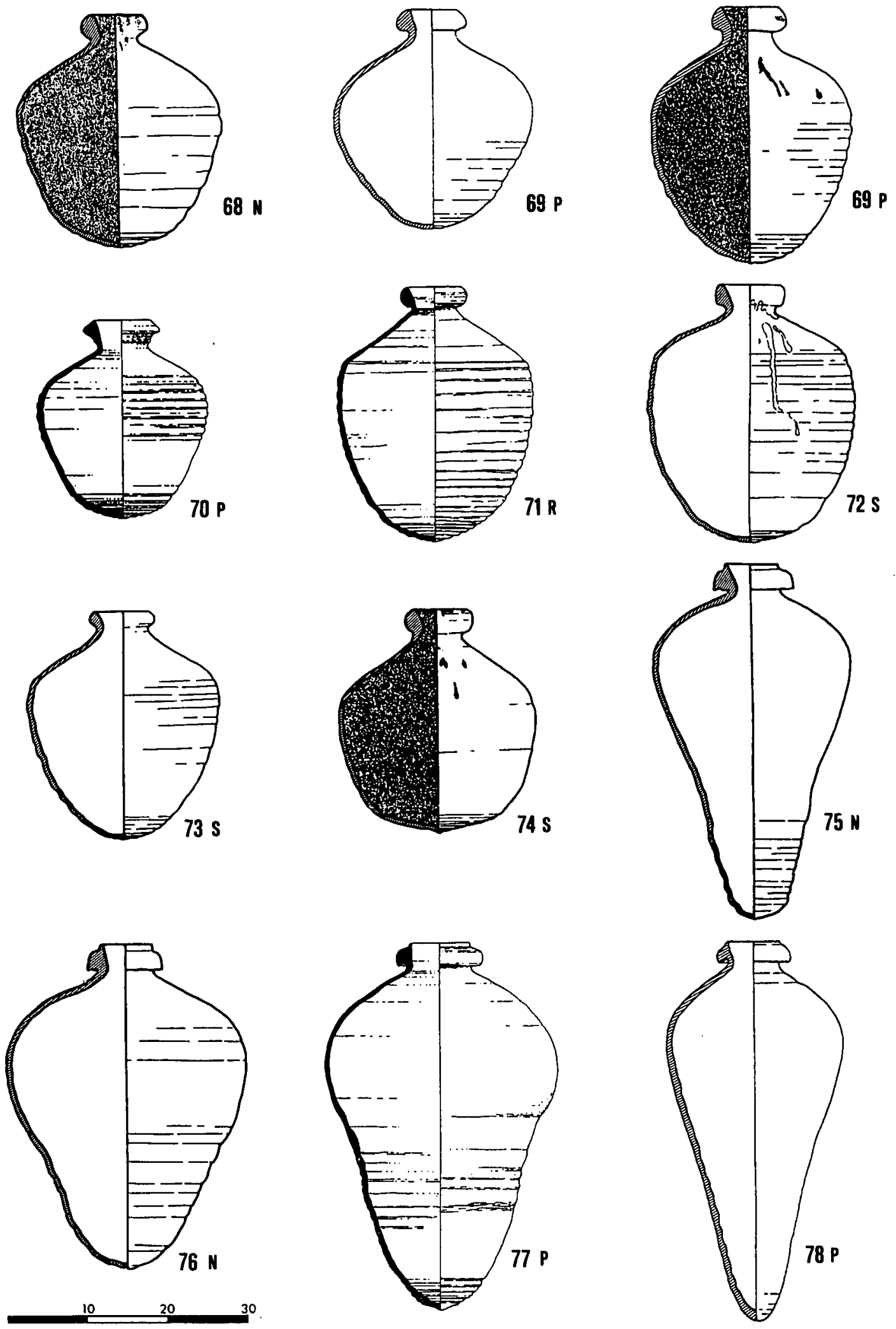

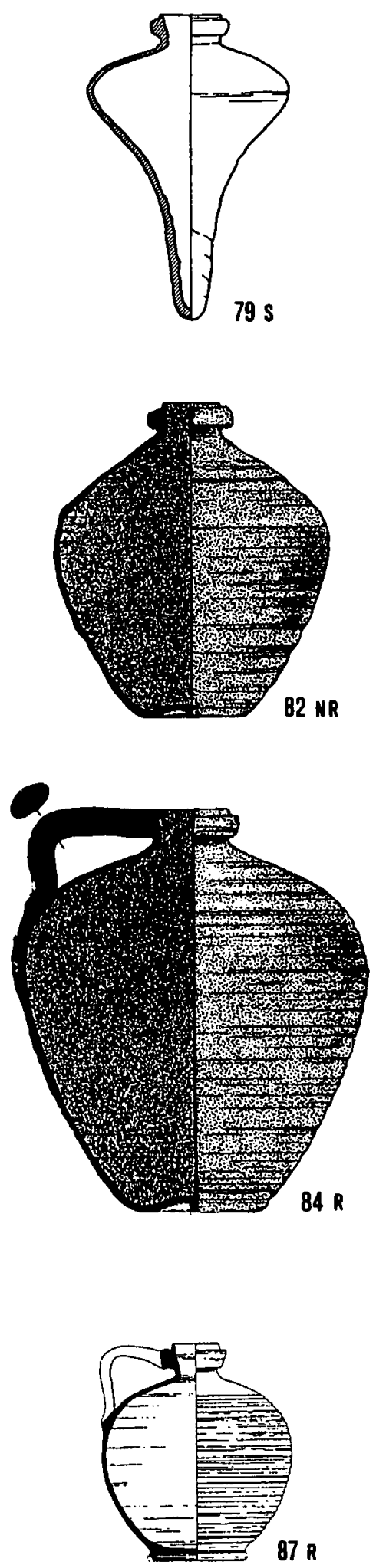
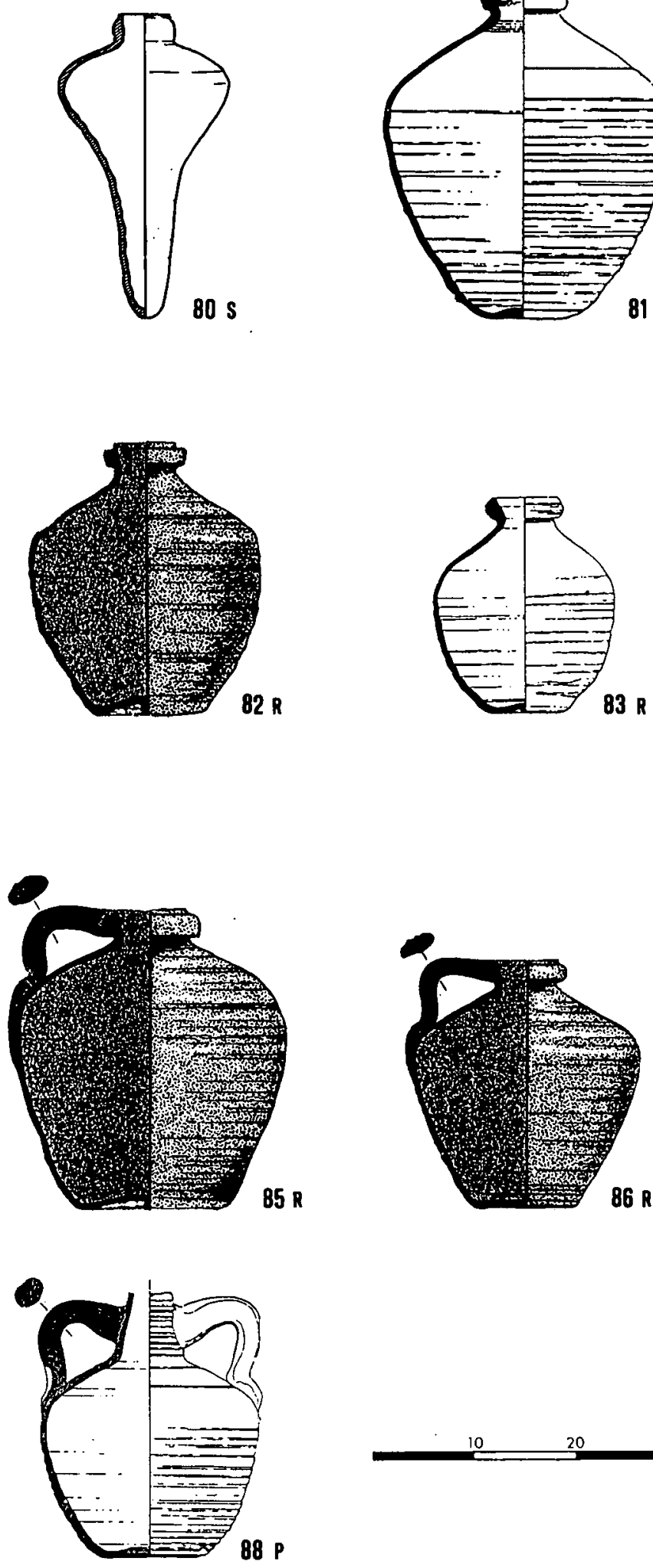
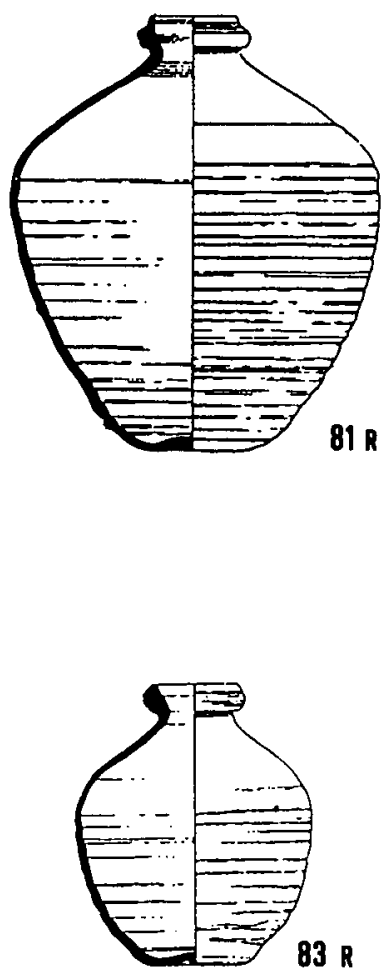

$83 \mathrm{R}$ 

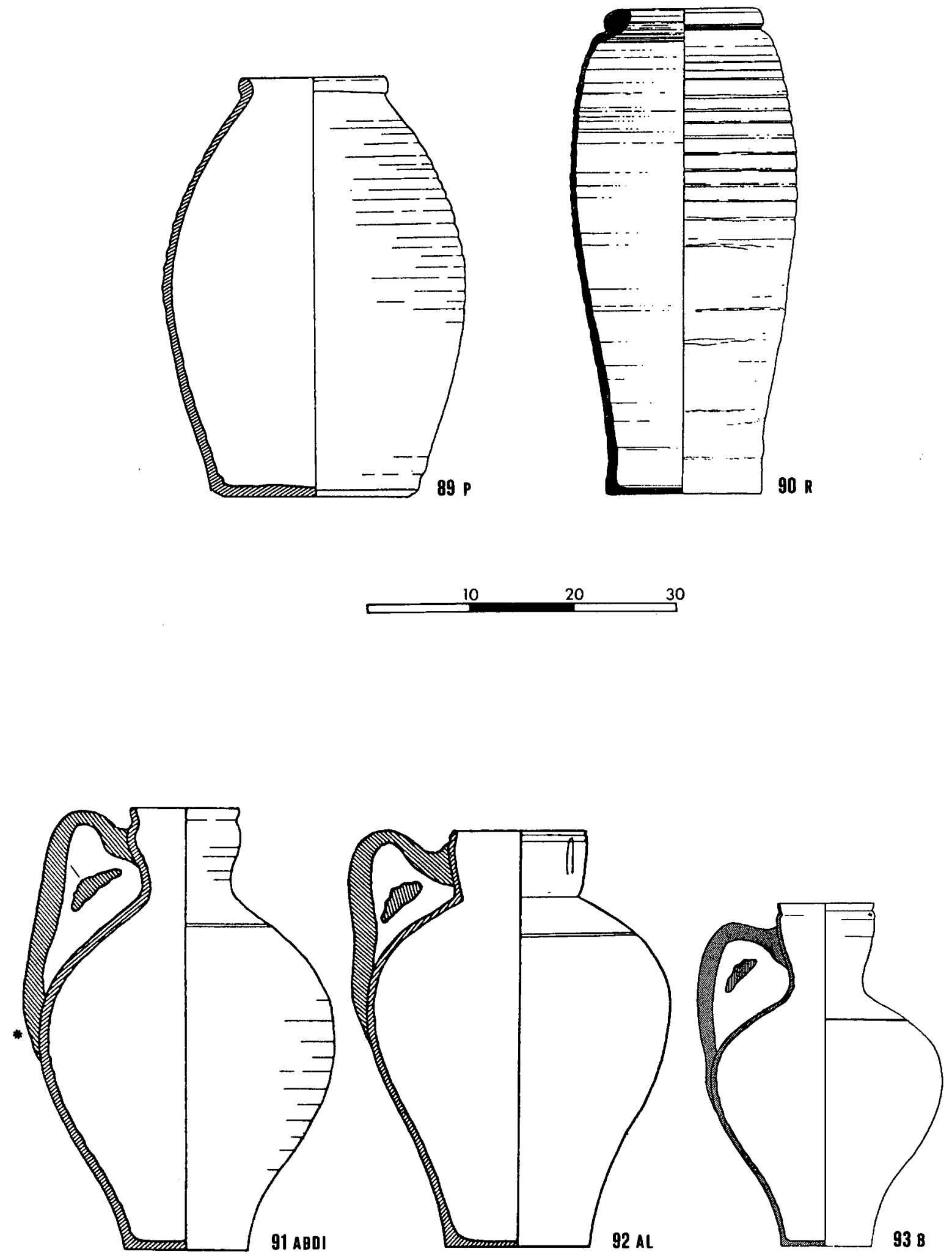

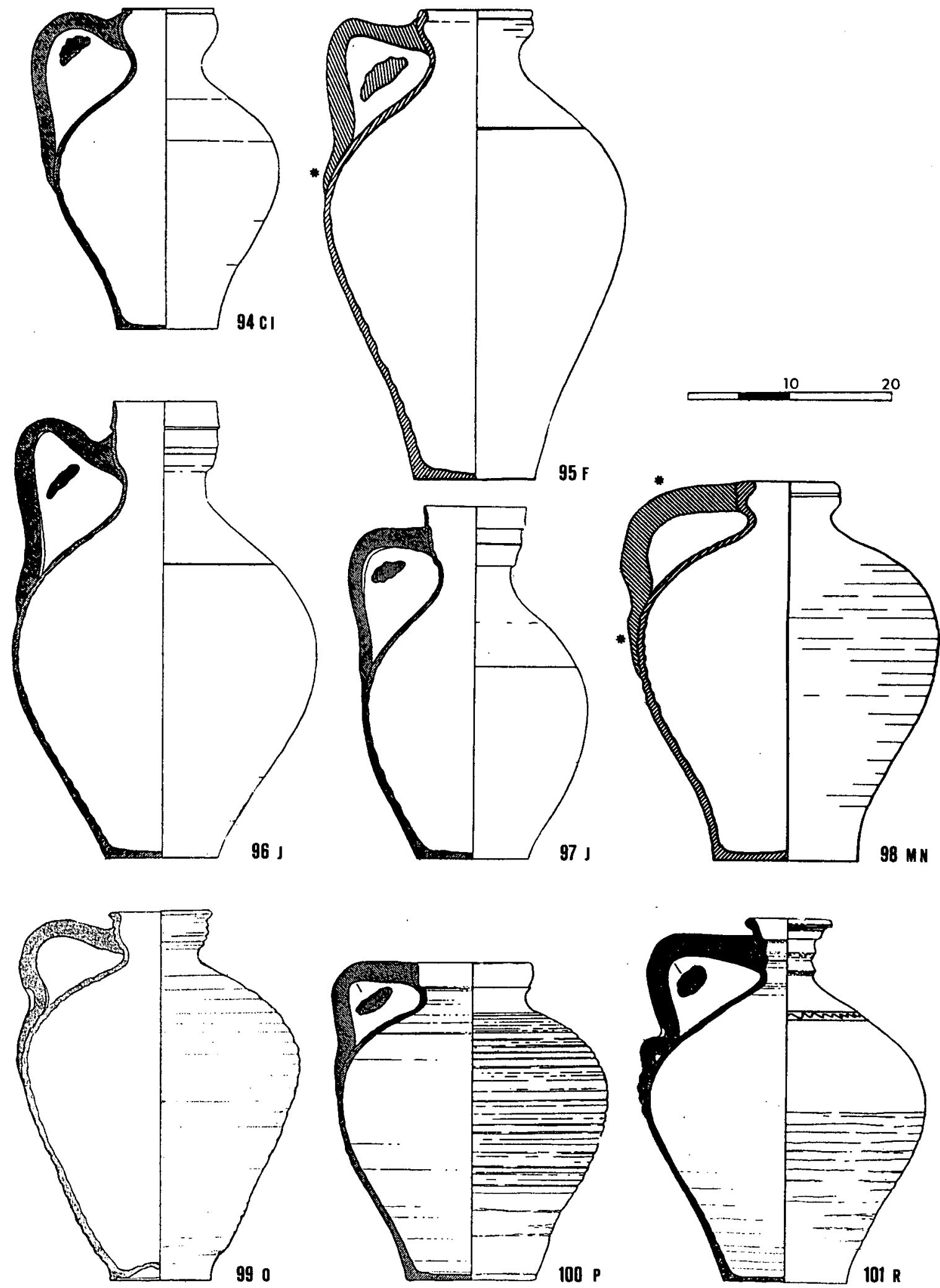

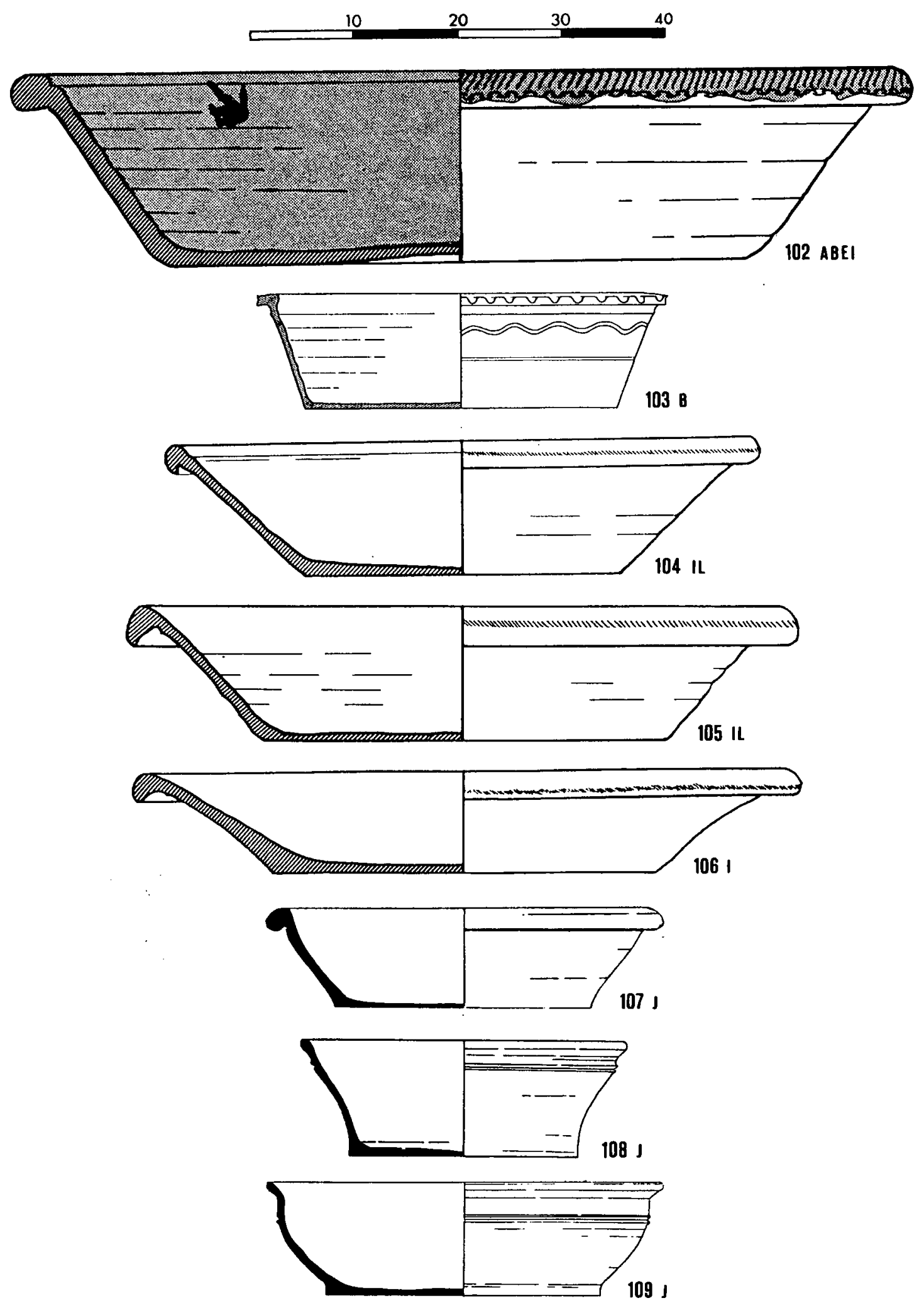

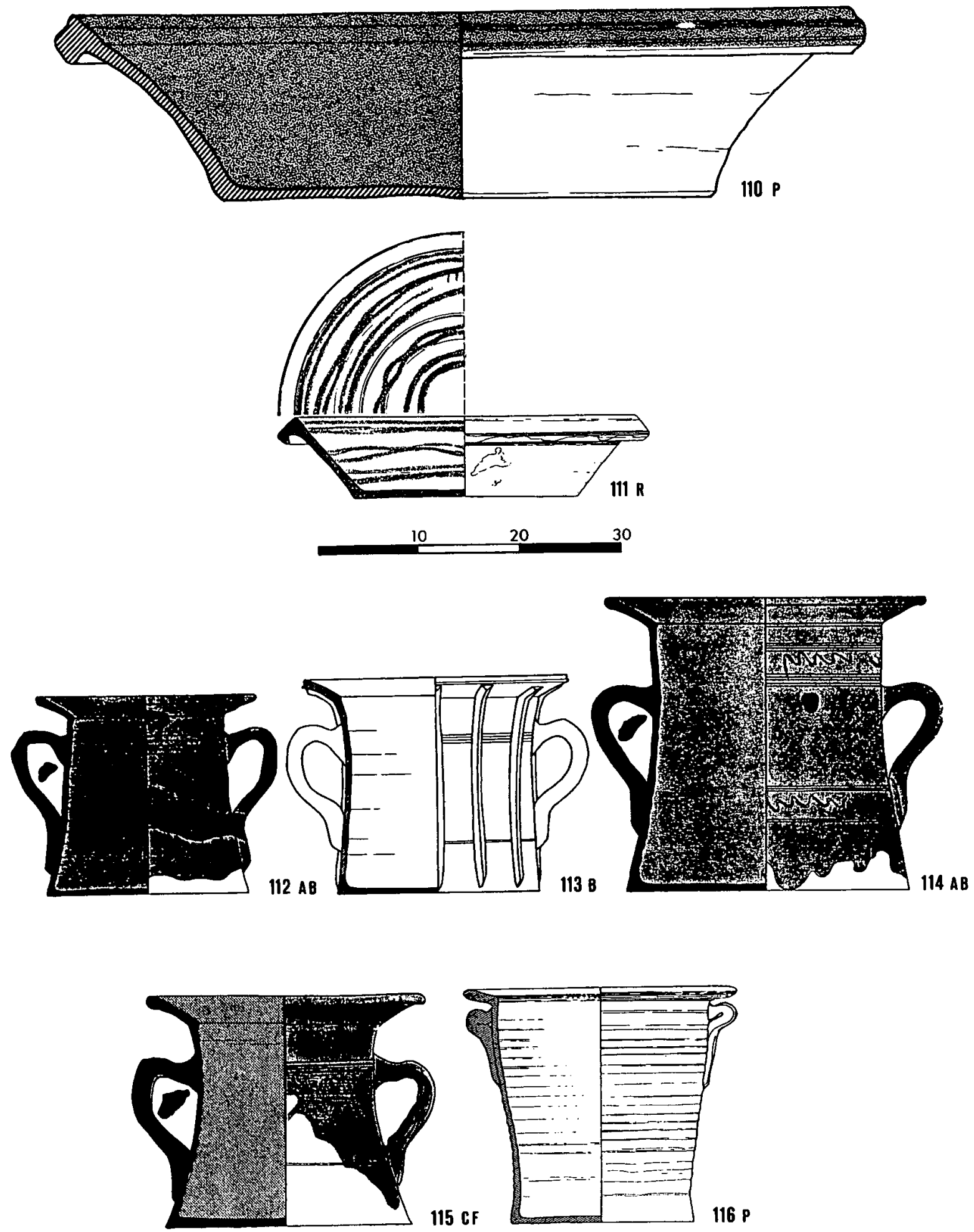

ISSN: 1133-4525 ISSN-e: 2255-3924

SPAL 2 (1993)

http://dx.doi.org/10.12795/spal.1993.i2.11 

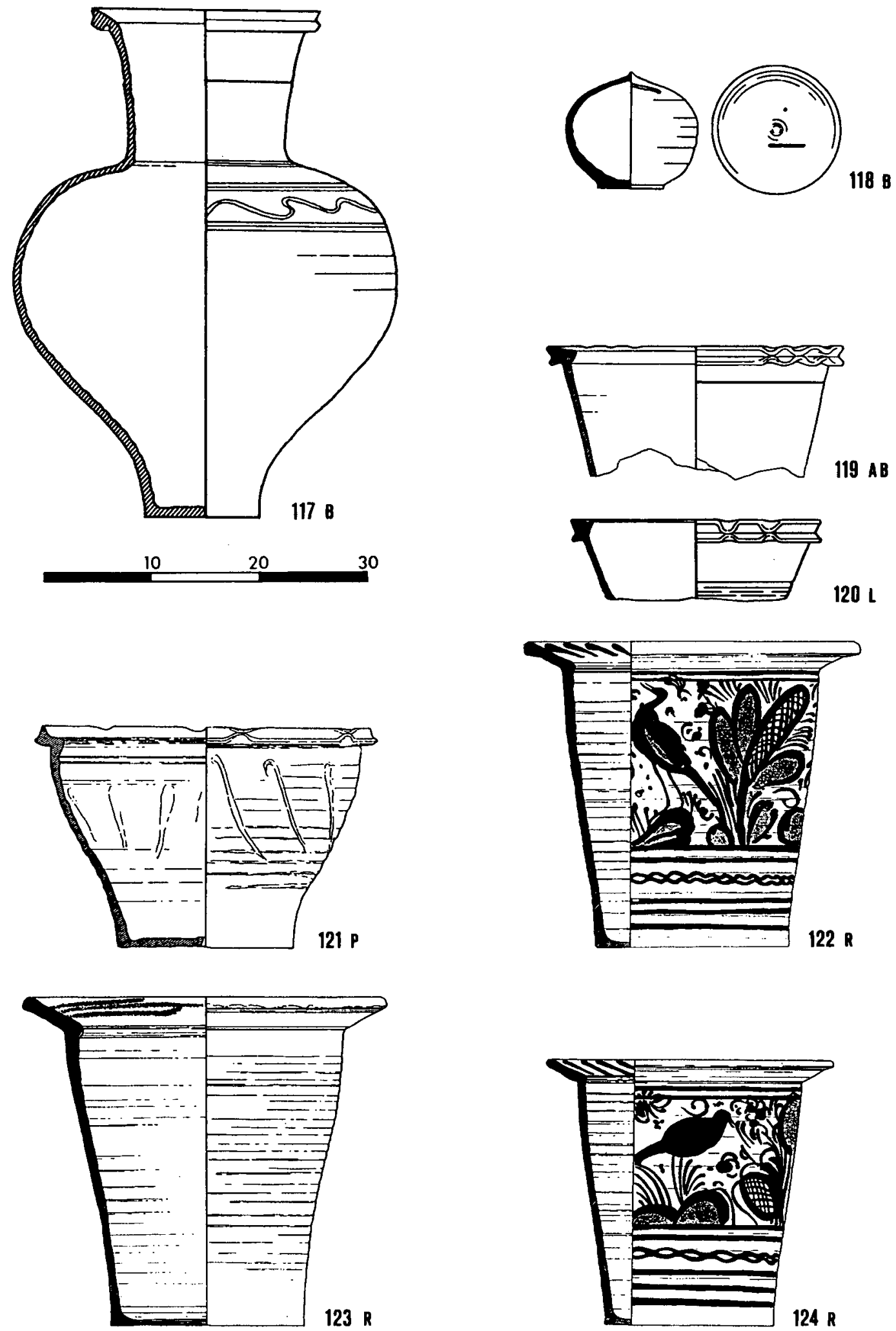

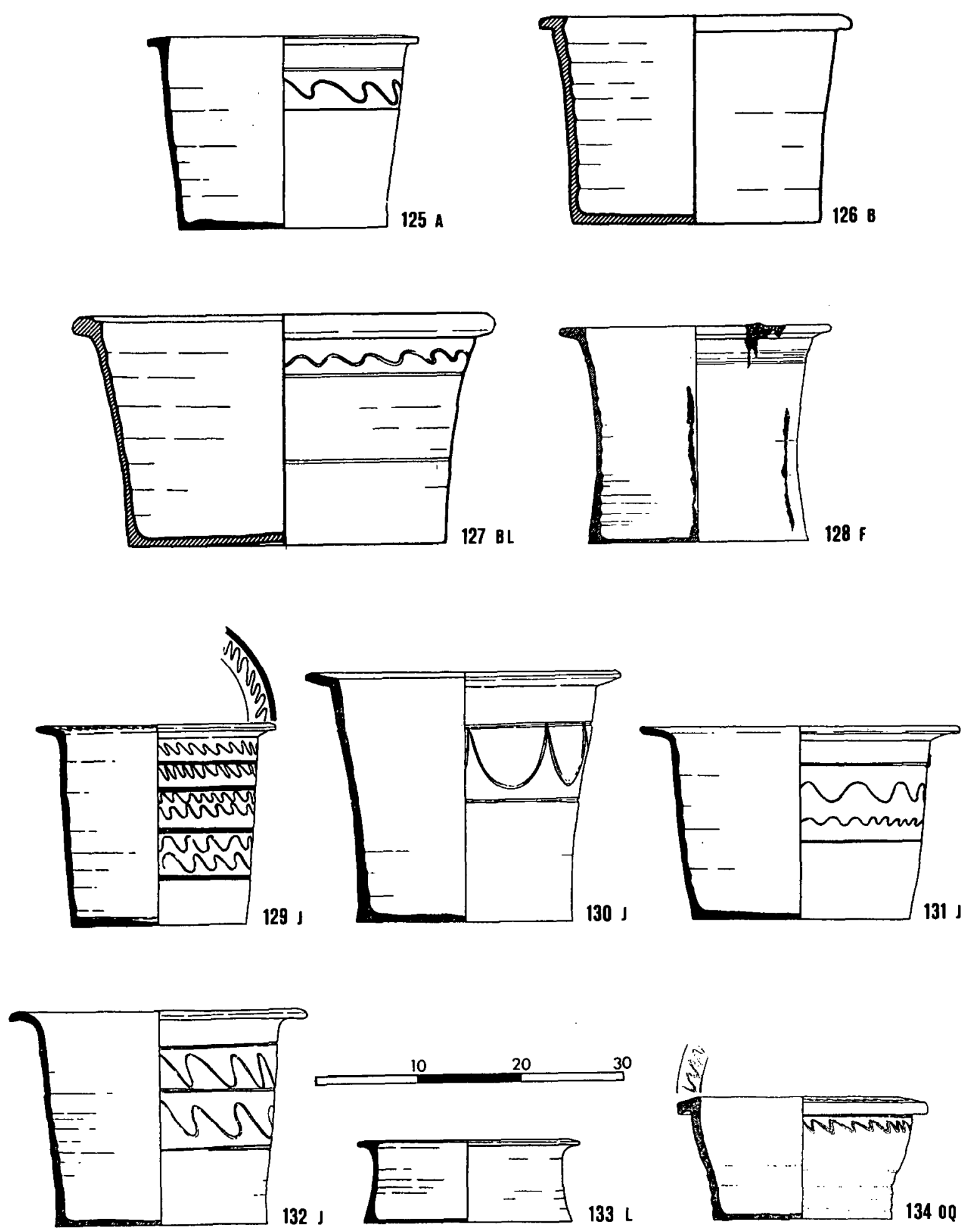

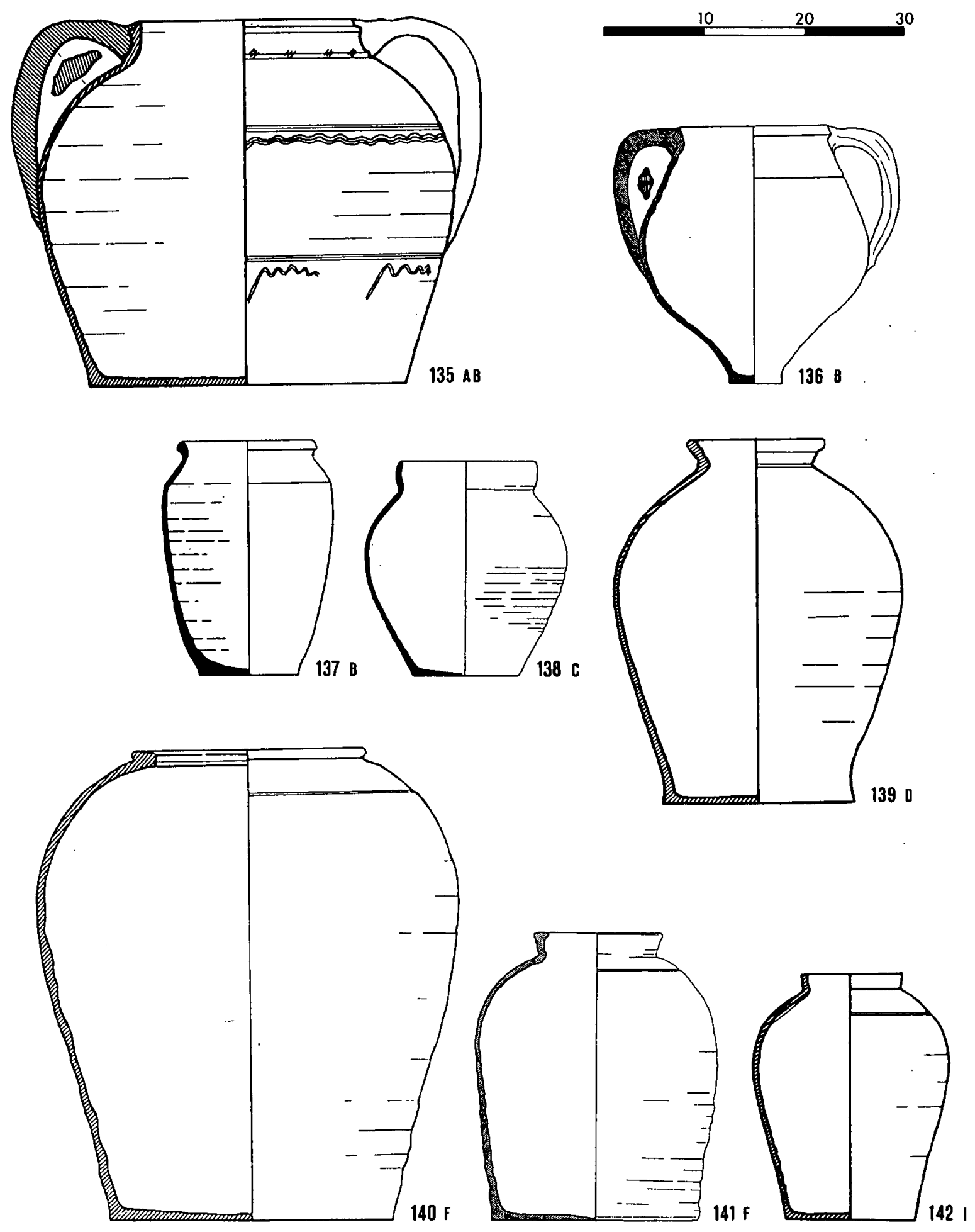

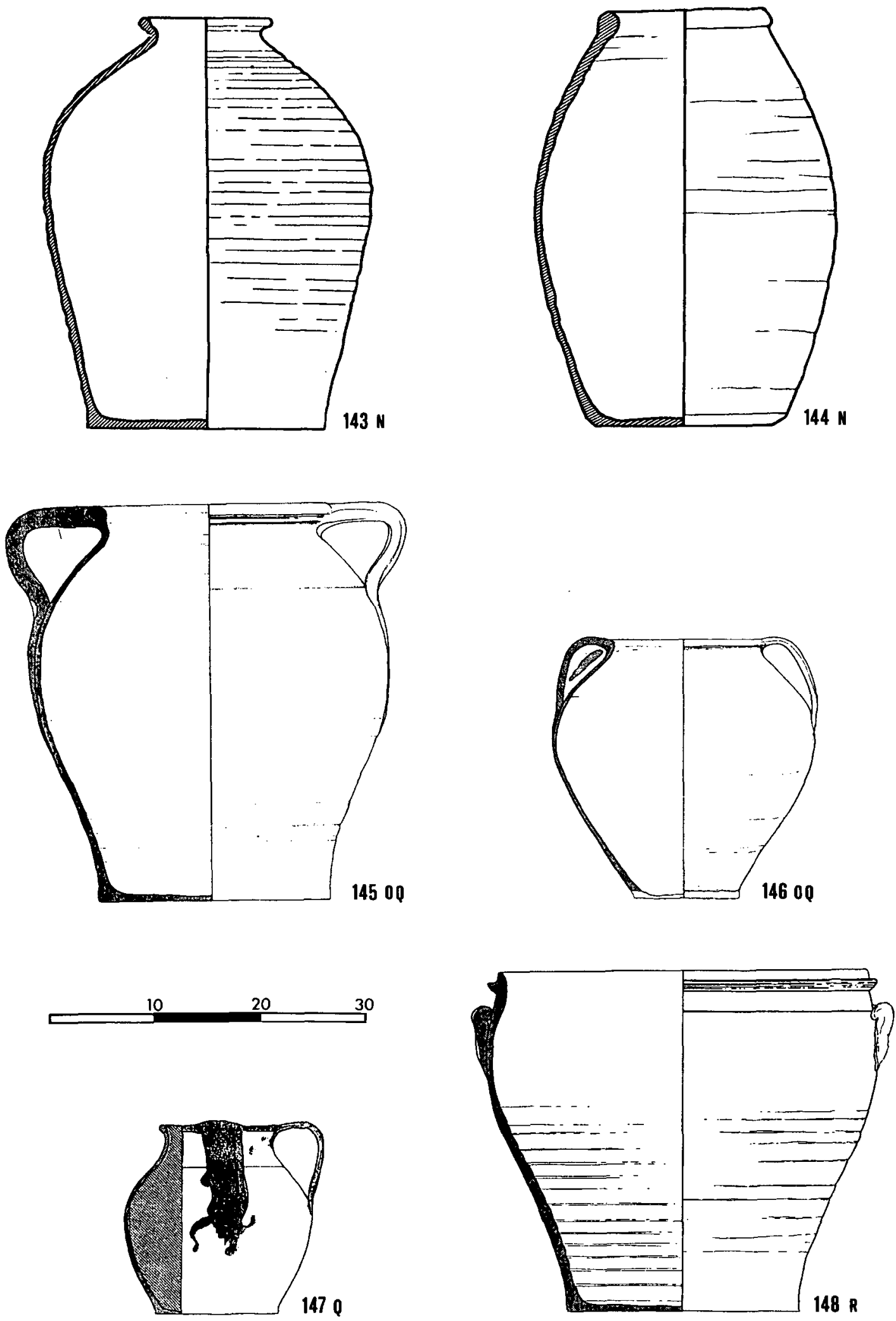

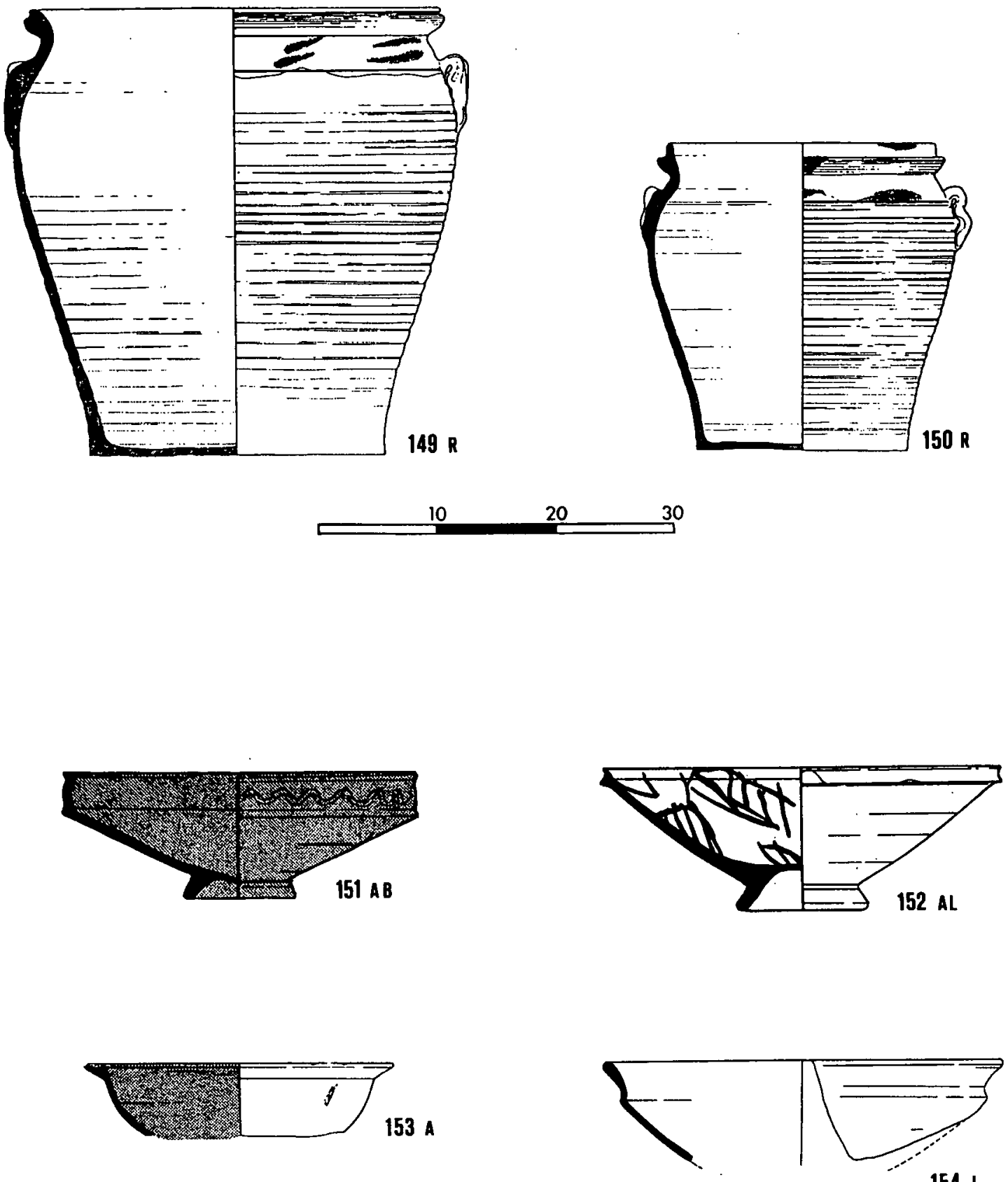

$154 \mathrm{~J}$
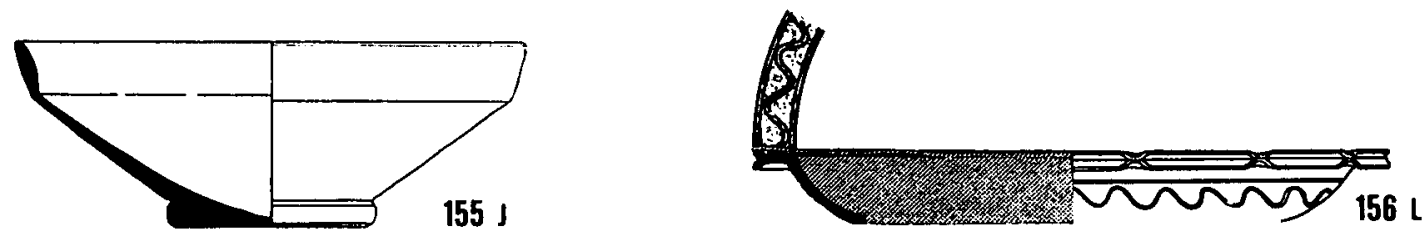

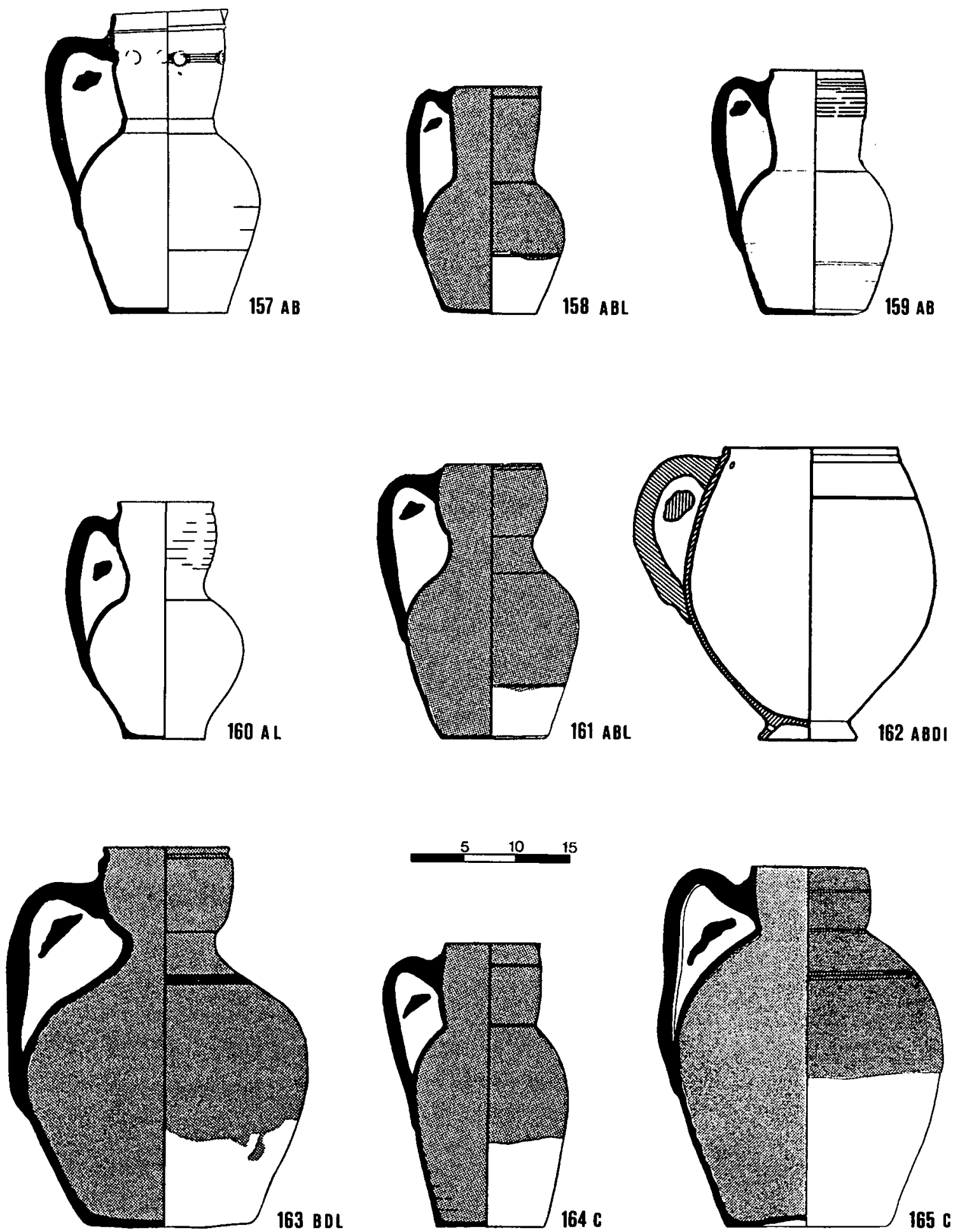

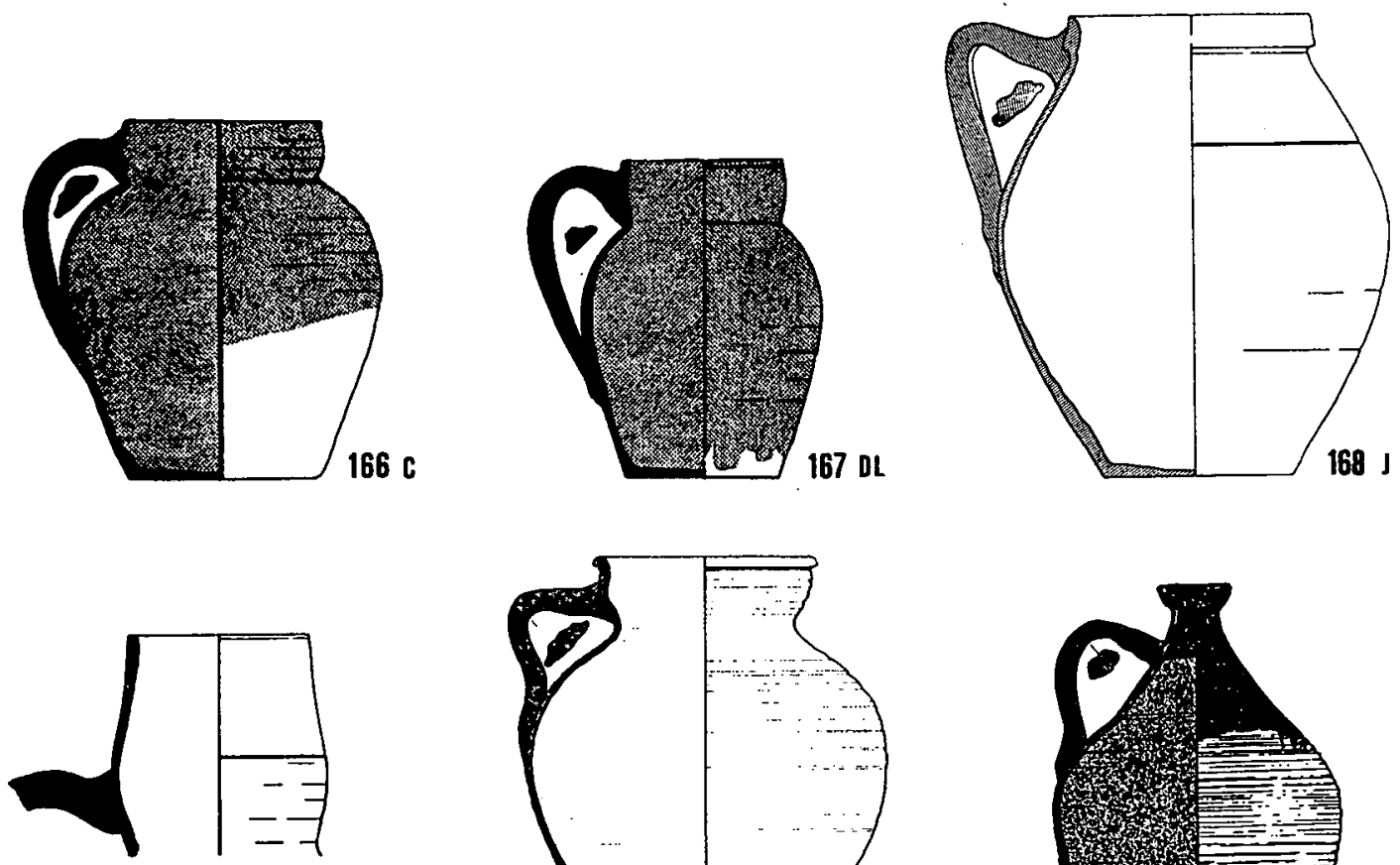

$169 \mathrm{~L}$
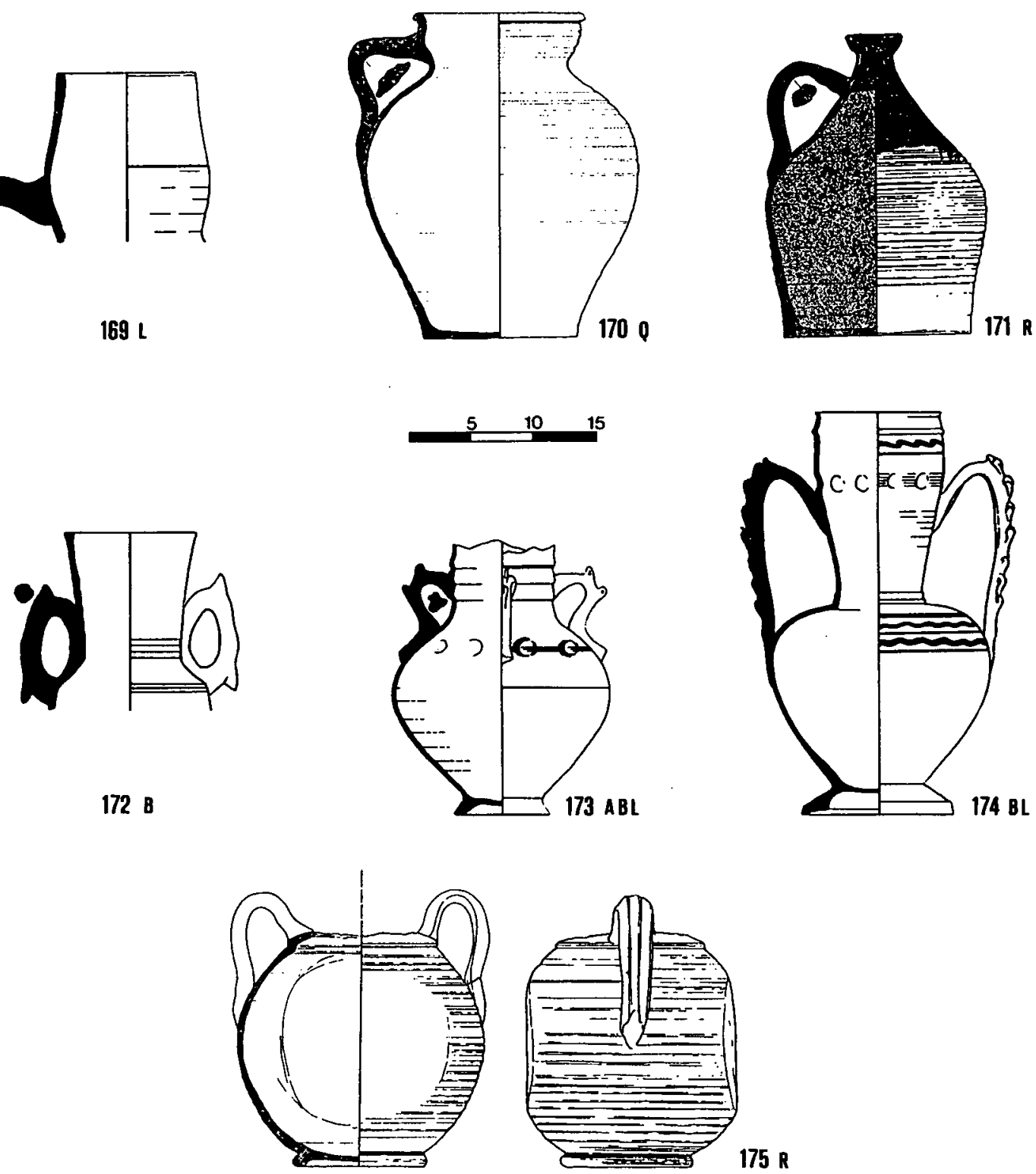

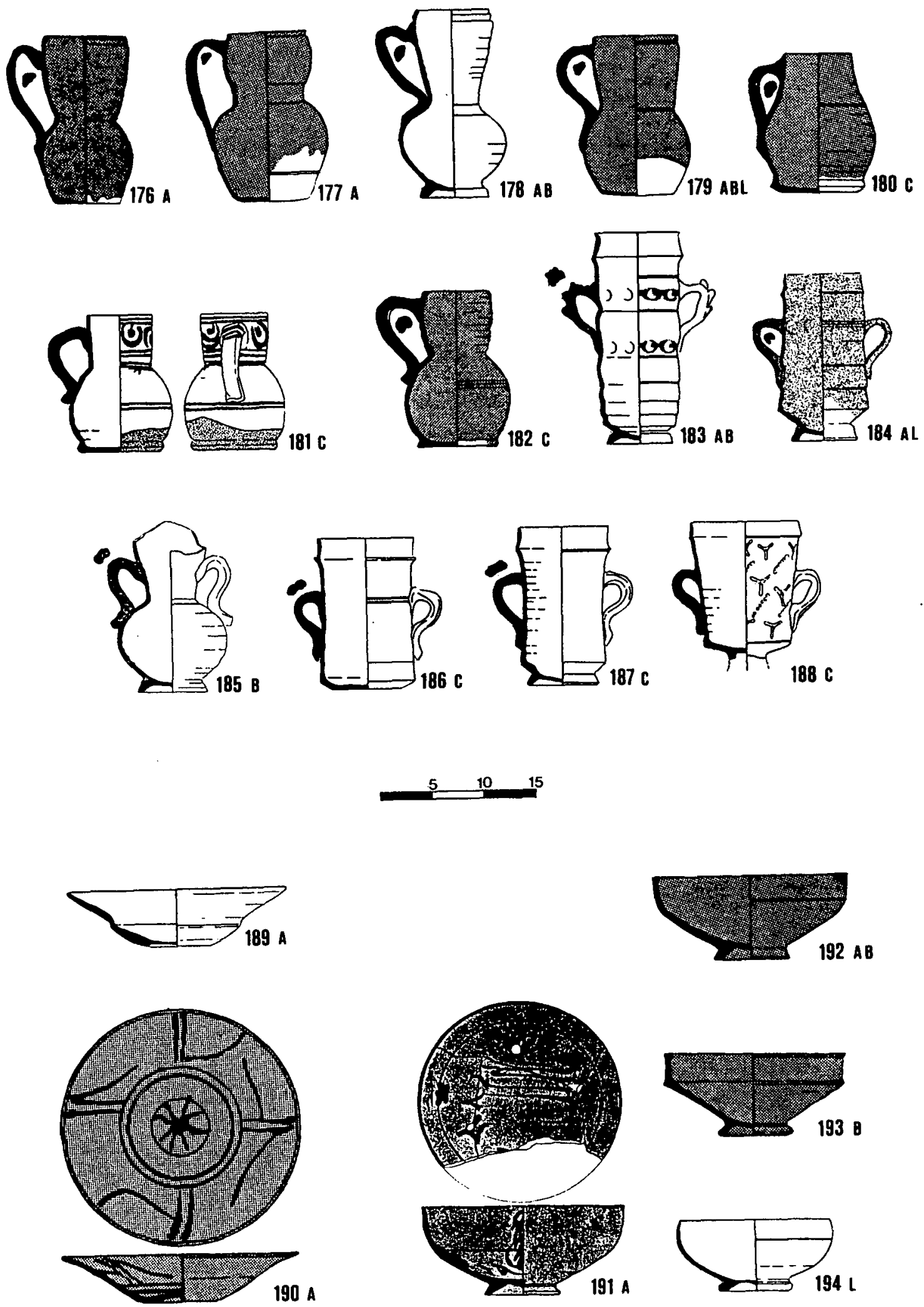

ISSN: 1133-4525 ISSN-e: 2255-3924

SPAL 2 (1993)

http://dx.doi.org/10.12795/spal.1993.i2.11 

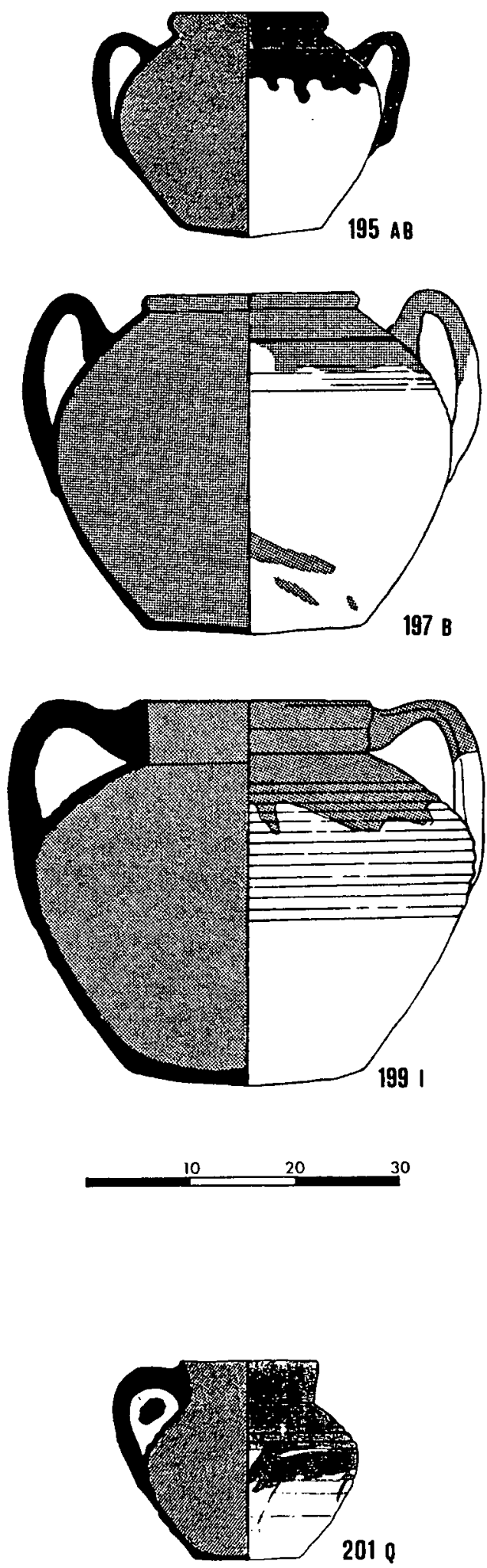
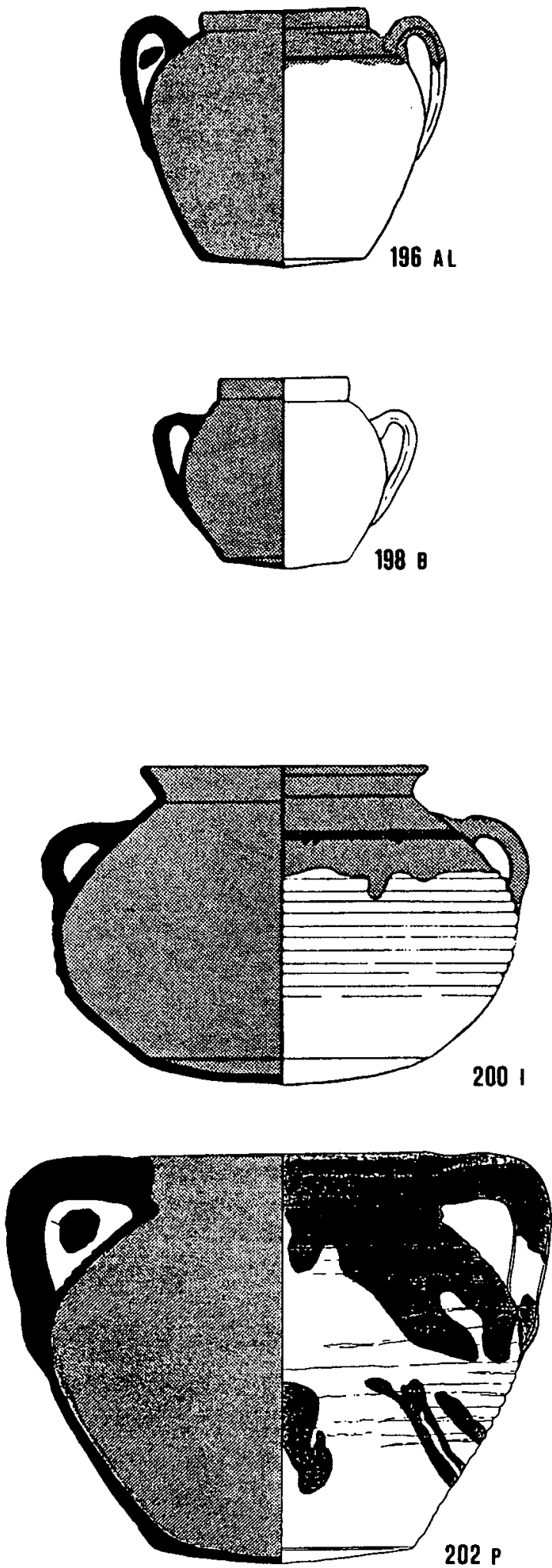

ISSN: 1133-4525 ISSN-e: 2255-3924 http://dx.doi.org/10.12795/spal.1993.i2.11 

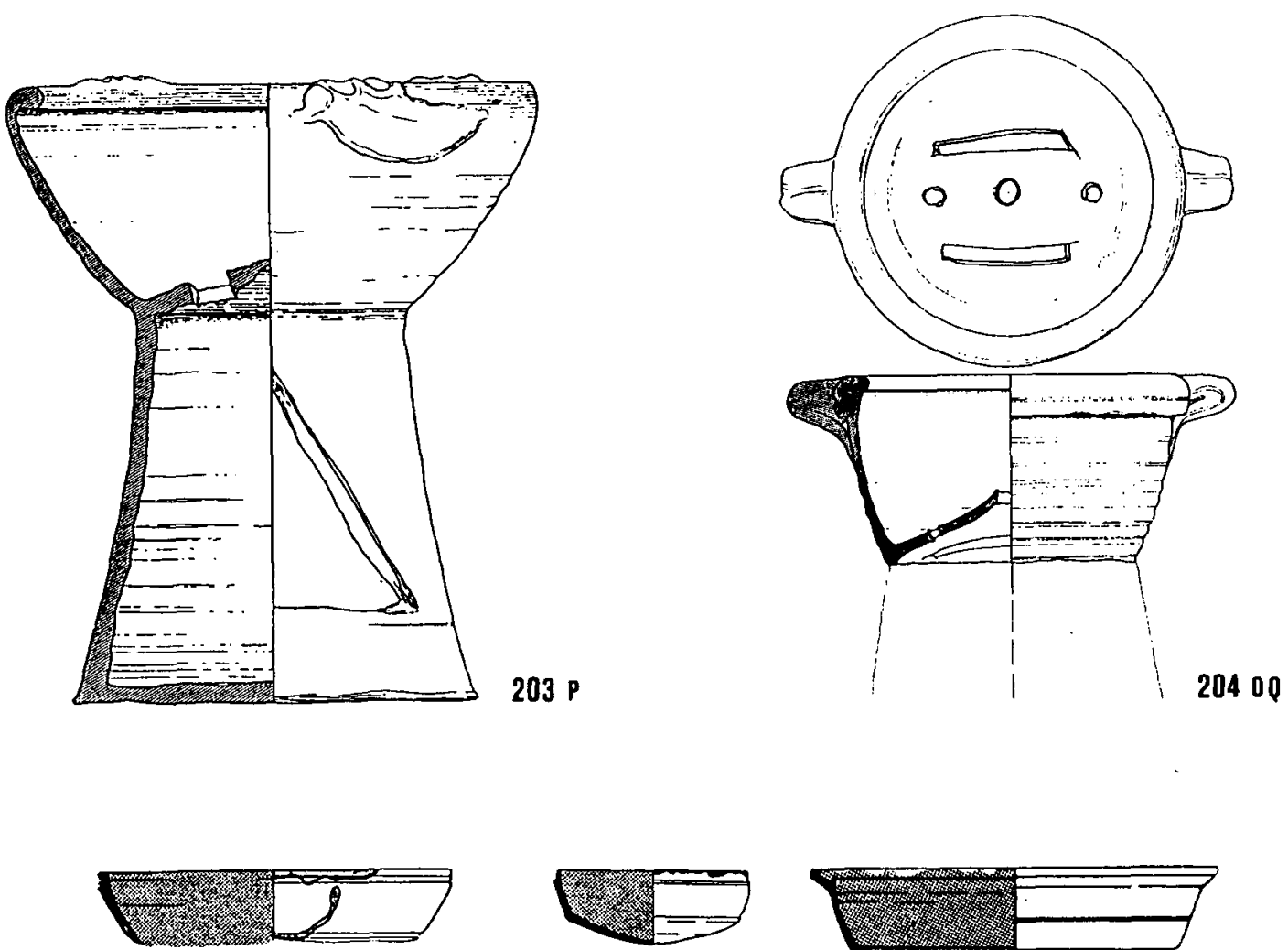

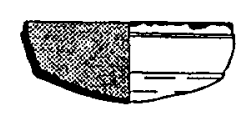

206 A

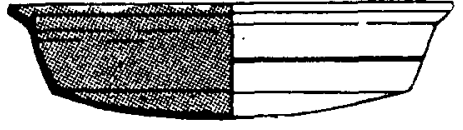

$207 \mathrm{~L}$

$205 \mathrm{~A}$
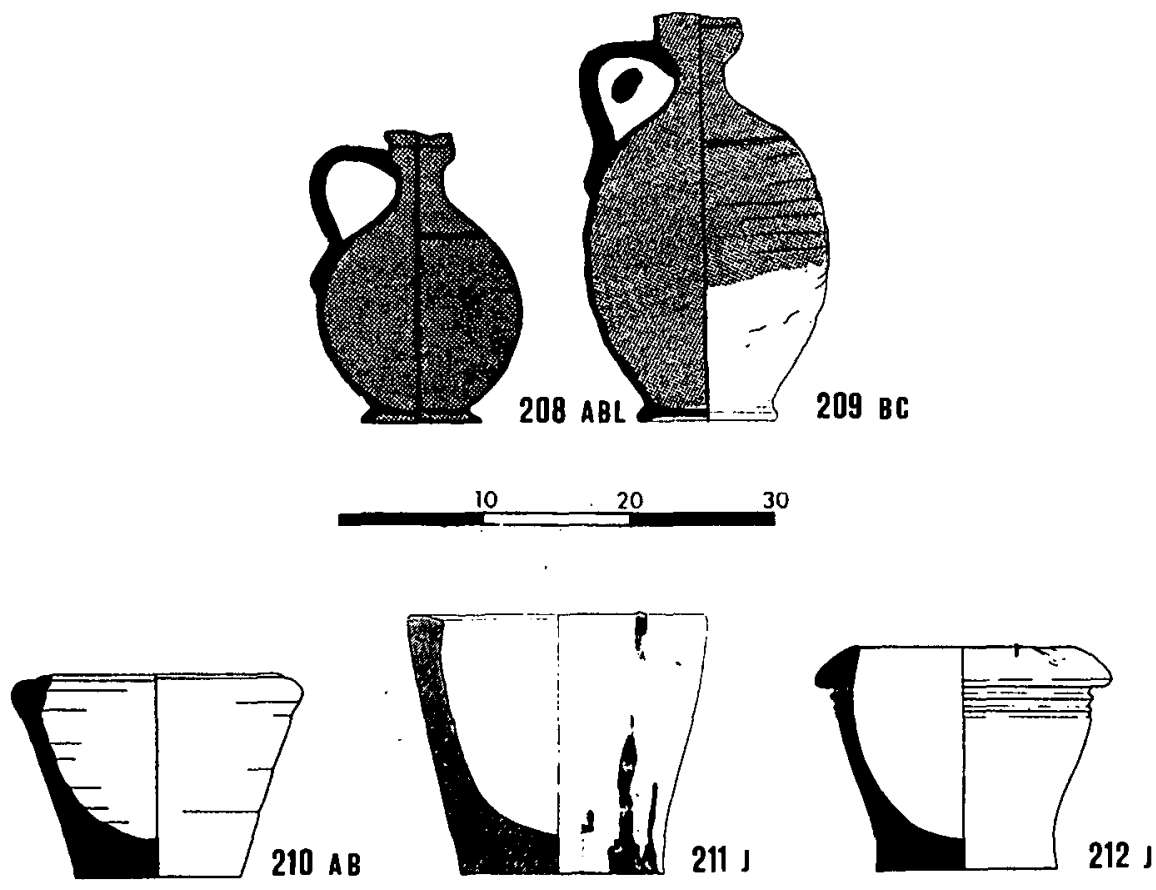

ISSN: 1133-4525 ISSN-e: 2255-3924

SPAL 2 (1993)

http://dx.doi.org/10.12795/spal.1993.i2.11 